\title{
Luminescent Pt-Ag Clusters based in Neutral Benzoquinolate Cyclometalated Platinum Complexes
}

\author{
Antonio Martín, ${ }^{[a]}$ Úrsula Belío, ${ }^{[a]}$ Sara Fuertes ${ }^{[a]}$ and Violeta Sicilia ${ }^{[b]}$
}

Dedicated to Prof. Juan Forniés on the occasion of his $65^{\text {th }}$ birthday

Keywords: Donor-acceptor systems, heterometallic complexes, Luminescence, metal-metal interactions, pi interactions, X-ray diffraction.

Complexes $\left[\mathrm{Pt}\left(\mathrm{C}_{6} \mathrm{~F}_{5}\right)(\mathrm{bzq}) \mathrm{L}\right] \quad$ bzq $=7,8$-benzoquinolinate; $\mathrm{L}=$ $\mathrm{PPh}_{3}$ (2), $\mathrm{pyPh}_{2}$ (3), tht (4), MeCN (5)\} are prepared by replacing the acetone ligand in $\left[\operatorname{Pt}\left(\mathrm{C}_{6} \mathrm{~F}_{5}\right)(\mathrm{bzq})\left(\mathrm{Me}_{2} \mathrm{CO}\right)\right]$ (1) with the corresponding $\mathrm{L}$. The structures of complexes $\mathbf{2}, \mathbf{3}$ and $\mathbf{4}$ have been established by X-ray diffraction. Despite their neutral nature, complexes 1-5 react with $\mathrm{AgClO}_{4}$ in 2:1 molar ratio giving the corresponding trinuclear $\left[\left\{\mathrm{Pt}\left(\mathrm{C}_{6} \mathrm{~F}_{5}\right)(\mathrm{bzq}) \mathrm{L}\right\}_{2} \mathrm{Ag}\right] \mathrm{ClO}_{4}\left\{\mathrm{~L}=\mathrm{Me}_{2} \mathrm{CO}\right.$ (6), $\mathrm{PPh}_{3}$ (7), $\mathrm{pyPh}_{2}$ (8), tht (9), $\left.\mathrm{MeCN}(\mathbf{1 0})\right\}$ which contain $\mathrm{Pt} \rightarrow \mathrm{Ag}$ dative bonds. The structures of complexes 7, 9 and $\mathbf{1 0}$ have been established by X-ray diffraction and confirm the existence of the Pt-Ag bonds (ca. $2.8 \AA$ ) and short $\eta^{1}$ bonding Ag-C interactions with the $\mathrm{C}_{i p s o}$ of the bzq (ca. $2.4 \AA$ ). Moreover, complexes 3, 4, 7, 9 and $\mathbf{1 0}$ show intermolecular $\pi \cdots \pi$ interactions between the aromatic rings of the bzq ligands (separations of $c a$. $3.5 \AA$ ). The reactions of 1-5 with $\left[\mathrm{Ag}\left(\mathrm{PPh}_{3}\right)\left(\mathrm{OClO}_{3}\right)\right]$ in 1:1 molar ratio proceed with interchange of ligands between the metals and formation of $\left[\left\{\mathrm{Pt}(\mathrm{bzq})\left(\mathrm{C}_{6} \mathrm{~F}_{5}\right)\left(\mathrm{PPh}_{3}\right)\right\}_{2} \mathrm{Ag}\right] \mathrm{ClO}_{4}(7)$ and $\left[\mathrm{AgL}_{2}\right] \mathrm{ClO}_{4}$ (X-ray). Only in the case of $\mathrm{L}=\mathrm{pyPh}_{2}$ (3), the dinuclear complex $\left[\left(\mathrm{C}_{6} \mathrm{~F}_{5}\right)(\mathrm{bzq})\left(\mathrm{PPh}_{3}\right) \mathrm{PtAg}\left(\mathrm{pyPh}_{2}\right)\right] \mathrm{ClO}_{4}(\mathbf{1 1})$ has been identified and its structure determined by X-ray diffraction. 11 contains a $\mathrm{Pt} \rightarrow \mathrm{Ag} \quad(2.8147(1) \quad \AA) \quad$ and $\quad \mathrm{a} \quad \eta^{1}-\mathrm{Ag}-\mathrm{C}_{i p s o}(\mathrm{bzq})$ interaction(2.293(1) $\AA$ ). The electronic absorption and luminescence behaviours of 1-11 have been investigated. The lower lying absorption bands of the mononuclear complexes are ascribed to ligand-centered [ ${ }^{1} \mathrm{IL}, \pi-\pi^{*}$ (bzq)] character mixed with some metal-to-ligand charge transfer [ ${ }^{1} \mathrm{MLCT}$ $\left(5 \mathrm{~d}(\mathrm{Pt}) \rightarrow \pi^{*}(\mathrm{bzq})\right]$. For the trinuclear complexes are assigned to ${ }^{1} \mathrm{ILCT} / \quad{ }^{1} \mathrm{MM} \mathrm{M}^{\prime} \mathrm{LCT} \quad\left[\pi-\pi^{*}(\mathrm{bzq})\right] / \quad\left(\mathrm{d} / \mathrm{s}(\mathrm{Pt}, \mathrm{Ag}) \quad \rightarrow \pi^{*}(\mathrm{bzq})\right]$ transitions and to mixed ${ }^{1} \mathrm{MLCT} /{ }^{1} \mathrm{~L}$ 'LCT
[MLCT $\left(5 \mathrm{~d}(\mathrm{Pt}) \rightarrow \pi^{*}(\mathrm{bzq})\right] / \quad$ [L'LCT, $\quad \mathrm{Ar}_{\mathrm{f}} \rightarrow$ bzq $]$ for the dinuclear complex 11, on the bases of Time-Dependent Density Functional Theory (TD-DFT) calculations carried out on 2, 4, 5, 9, 10 and $11 \mathrm{Me}$ in $\mathrm{CH}_{2} \mathrm{Cl}_{2}$. Only 2 and the heteronuclear compounds are emissive in the solid state at room temperature, however all of them are emissive at $77 \mathrm{~K}$ (solid and glasses). The main phosphorescent emission seems in each case to be due to a transition similar in character to the lowest energy electronic absorption. [a] Instituto de Síntesis Química y Catálisis Homogénea (ISQCH), CSIC Universidad de Zaragoza, Departamento de Química Inorgánica, Facultad de Ciencias, 50009 Zaragoza, Spain.

[b] Instituto de Síntesis Química y Catálisis Homogénea (ISQCH), CSIC Universidad de Zaragoza, Departamento de Química Inorgánica, Escuela de Ingeniería y Arquitectura de Zaragoza, Campus Río Ebro, Edificio Torres Quevedo, 50018, Zaragoza Spain.

Supporting information for this article is available on the WWW under http://www.eurjic.org/ or from the author.

\section{Introduction}

Metallophilic interactions between closed or pseudo closed shell transition metals $\left(\mathrm{d}^{10}, \mathrm{~d}^{8}, \mathrm{~d}^{10} \mathrm{~s}^{2}\right)$ is a field of great interest in Inorganic Chemistry. ${ }^{[1-12]}$ In this respect, square planar complexes of $\mathrm{Pt}(\mathrm{II})$ are a particular well suited system which has allowed to prepare a huge variety of heteropolymetallic complexes involving $\mathrm{Pt}(\mathrm{II})\left(\mathrm{d}^{8}\right) \rightarrow \mathrm{M}$ dative bonds, ${ }^{[5,13-32]}$ being the acidic $\mathrm{M}$ centre $\mathrm{Cu}(\mathrm{I})$, $\mathrm{Ag}(\mathrm{I}), \mathrm{Au}(\mathrm{I}), \mathrm{Cd}(\mathrm{II}), \mathrm{Hg}(\mathrm{II}), \mathrm{Tl}(\mathrm{I}), \mathrm{Sn}(\mathrm{II})$ and $\mathrm{Pb}(\mathrm{II})$.

These metal-metal bonds can be used as a tool in molecular or crystal engineering, acting as a sort of link between different subassemblies. Thus, a wide array of interesting structural types, involving different nuclearities have been reported, from simple linear bimetallic compounds to infinite one-dimensional chains. ${ }^{[15-}$ 19, 22-24, 30, 32-39]. Besides, among other interesting properties, some complexes containing $\mathrm{Pt}-\mathrm{Ag}$ bonds have been shown to exhibit interesting photophysical and photochemical properties, ${ }^{[1-10,18,31,39-}$ 53] which in some cases have been exclusively attributed to the presence of metallophilic bonds.

In the course of our current research, we have developed synthetic methods for the preparation of complexes containing Pt$M$ bonds, mainly based on the use of perhalophenyl platinate(II) complexes. ${ }^{[13,16,17,34,37,38,54-57]}$ We expanded this work with the simultaneous use of strong ligand field cyclometalated $\mathrm{C} \wedge \mathrm{N}$ ligands, such as 7,8-benzoquinolinate (bzq). ${ }^{[16,17,39,53]}$ This strong ligand field causes the $d_{z}$ platinum orbital to raises its energy and favours the formation of stronger $\mathrm{Pt} \rightarrow \mathrm{M}$ dative bonds. ${ }^{[58,59]}$ Thus, we have reported that the anionic $\left[\mathrm{Pt}(\mathrm{bzq})\left(\mathrm{C}_{6} \mathrm{X}_{5}\right)_{2}\right]^{-}(\mathrm{X}=\mathrm{F}, \mathrm{Cl})$ is a suitable starting material for the preparation of complexes with unsupported $\mathrm{Pt}-\mathrm{M}$ bonds. ${ }^{[16,17,39]}$ Depending on the reaction conditions, the complexes obtained show different structural features: bimetallic Pt-M $\left[\left\{\mathrm{Pt}(\mathrm{bzq})\left(\mathrm{C}_{6} \mathrm{X}_{5}\right)_{2}\right\} \mathrm{ML}\right]^{n+}(\mathrm{M}=\mathrm{Cd}, \mathrm{L}=$ cyclen, $\mathrm{X}=\mathrm{F} n=$ $1 ;{ }^{[16]} \mathrm{M}=\mathrm{Ag}, \mathrm{L}=\mathrm{PPh}_{3}, \mathrm{X}=\mathrm{F}$ or $\mathrm{Cl}, n=0^{[17,39]}, \mathrm{M}=\mathrm{Ag}, \mathrm{L}=$ tetrahydrothiophene (tht), $\left.X=F, n=0^{[17,} 39\right]$ ), trimetallic 
"sandwich" Pt-Ag-Pt $\left[\left\{\mathrm{Pt}(\mathrm{bzq})\left(\mathrm{C}_{6} \mathrm{~F}_{5}\right)_{2}\right\}_{2} \mathrm{Ag}\right]^{-17}$ or the polymer metallic chain system $\cdots \mathrm{Pt}-\mathrm{Ag}-\mathrm{Pt}-\mathrm{Ag}-\mathrm{Pt} \cdot \cdots$ $\left[\left\{\mathrm{Pt}(\mathrm{bzq})\left(\mathrm{C}_{6} \mathrm{~F}_{5}\right)_{2}\right\} \mathrm{Ag}\right]_{\mathrm{x}} \cdot{ }^{39}$ All the Pt-Ag complexes, besides the intermetallic bonds, also contain very unusual $\eta^{1}$ bonding interactions between the silver(I) centre and the $\mathrm{C}_{i p s o}$ of the bzq ligand and are additionally stabilized by short or long-range $\pi \cdots \pi$ stacking interactions between the aromatic rings of the bzq ligands.

All these complexes exhibited interesting photoluminescent properties. For complexes $\left[\left\{\mathrm{Pt}(\mathrm{bzq})\left(\mathrm{C}_{6} \mathrm{~F}_{5}\right)_{2}\right\} \mathrm{Ag}(\mathrm{L})\right]$ (and also for $\left[\left\{\mathrm{Pt}(\mathrm{bzq})\left(\mathrm{C}_{6} \mathrm{~F}_{5}\right)_{2}\right\} \mathrm{Ag}\right]_{\mathrm{x}}$ upon dissolution in donor solvents as acetone or THF) the formation of the $\mathrm{Pt}-\mathrm{Ag}$ bond produces a significant blue shift of the lowest-lying absorption in relation to the starting material $\left[\mathrm{Pt}(\mathrm{bzq})\left(\mathrm{C}_{6} \mathrm{X}_{5}\right)_{2}\right]^{-}$. This fact has been attributed to the stabilization and modification of the nature of the HOMO, which changes the character of the transition from ${ }^{1} \mathrm{IL} /{ }^{1} \mathrm{MLCT}$ in $\left[\mathrm{Pt}(\mathrm{bzq})\left(\mathrm{C}_{6} \mathrm{~F}_{5}\right)_{2}\right]^{-}$to admixture ${ }^{1} \mathrm{~L}$ 'LCT $/{ }^{1} \mathrm{MLCT}$ with a lower weight of the ${ }^{1}$ MLCT in the bimetallic fragments. The emission in $\left[\left\{\mathrm{Pt}(\mathrm{bzq})\left(\mathrm{C}_{6} \mathrm{~F}_{5}\right)_{2}\right\} \mathrm{Ag}(\mathrm{L})\right]$ is also mainly associated to an admixture of ${ }^{3} \mathrm{MLCT} /{ }^{3} \mathrm{~L}$ 'LCT, only slightly modified by the Ag centre. By contrast, both the experimental data in solid state and the theoretical calculations on "[ $\left.\left\{\mathrm{Pt}(\mathrm{bzq})\left(\mathrm{C}_{6} \mathrm{~F}_{5}\right)_{2}\right\} \mathrm{Ag}\right]$ " as the model for $\left[\left\{\mathrm{Pt}(\mathrm{bzq})\left(\mathrm{C}_{6} \mathrm{~F}_{5}\right)_{2}\right\} \mathrm{Ag}\right]_{\mathrm{X}}$ suggest that excitation of the polymer moves electron density from the platinum fragments, the $\mathrm{C}_{6} \mathrm{~F}_{5}$ rings having a remarkable contribution to an orbital with a strong Pt, $\mathrm{Ag}$ metallic character. Absorption and emission of the polymer in the solid state is therefore suggested to be associated with an electronic transition of a mixed [Pt(bzq) $\rightarrow \mathrm{Ag}] /\left[\mathrm{Ar}_{\mathrm{f}} \rightarrow \mathrm{Ag}\right]$ character. For the trimetallic complex $\left[\left\{\mathrm{Pt}(\mathrm{bzq})\left(\mathrm{C}_{6} \mathrm{~F}_{5}\right)_{2}\right\}_{2} \mathrm{Ag}\right]^{-}$, two different polymorphs were obtained from acetone/ $n$-hexane, exhibiting visibly different luminescences at room temperature. The crystal structures of both of the anions are different, not only in their form, with a different conformation of the platinum planes, but also in terms of packing.

In this paper we continue our study on this kind of complexes exploring the ability of the starting materials $\left[\mathrm{Pt}(\mathrm{bzq})\left(\mathrm{C}_{6} \mathrm{~F}_{5}\right)(\mathrm{L})\right](\mathrm{L}$ $=\mathrm{Me}_{2} \mathrm{CO}, \mathrm{PPh}_{3}, \mathrm{pyPh}_{2}$, tht, MeCN) to form new complexes of diverse nuclearity containing $\mathrm{Pt}-\mathrm{Ag}$ bonds. In principle, the neutral $\left[\mathrm{Pt}(\mathrm{bzq})\left(\mathrm{C}_{6} \mathrm{~F}_{5}\right)(\mathrm{L})\right]$ have a drawback with respect to the previously used $\left[\mathrm{Pt}(\mathrm{bzq})\left(\mathrm{C}_{6} \mathrm{X}_{5}\right)_{2}\right]^{-}$, since the anionic nature of this later should increase the electron density on the Pt centre and thus favour the $\mathrm{Pt} \rightarrow$ Ag dative bond. ${ }^{[13]}$ Nevertheless, there are examples of neutral platinum complexes used as starting materials in the preparation of $\mathrm{Pt} \rightarrow$ Ag dative bonds with success. ${ }^{[2,53]}$ Thus, after the preparation of the corresponding $\left[\mathrm{Pt}(\mathrm{bzq})\left(\mathrm{C}_{6} \mathrm{~F}_{5}\right)(\mathrm{L})\right]$ starting materials, we have achieved the preparation of several trimetallic $\mathrm{Pt}-\mathrm{Ag}-\mathrm{Pt}$ and one bimetallic Pt-Ag complexes, which have been characterised and studied by X-ray crystallography and NMR spectroscopy. Finally, their optical properties have been investigated and time-dependent density functional theory (TD-DFT) calculations have been performed to gain a better insight into the nature of the electronic transitions.

\section{Results and Discussion}

Synthesis and characterization of the cyclometalated complexes $\left[\mathrm{Pt}\left(\mathrm{C}_{6} \mathrm{~F}_{5}\right)(\mathrm{bzq}) \mathrm{L}\right]\left\{\mathrm{L}=\mathrm{PPh}_{3}\right.$ (2), $\mathrm{pyPh}_{2}$ (3), tht (4), $\operatorname{MeCN}(5)\}$

Complex $\left[\mathrm{Pt}\left(\mathrm{C}_{6} \mathrm{~F}_{5}\right)(\mathrm{bzq})\left(\mathrm{Me}_{2} \mathrm{CO}\right)\right]$ (1) is a suitable precursor for the preparation of complexes $\left[\mathrm{Pt}\left(\mathrm{C}_{6} \mathrm{~F}_{5}\right)(\mathrm{bzq}) \mathrm{L}\right]$ because the acetone group is easily replaced by other L ligands. ${ }^{[60]}$ Thus, the addition of equimolar amounts of $\mathrm{PPh}_{3}, \mathrm{pyPh}_{2}$ (2,6-diphenylpyridine) or tht (tetrahydrothiophene, $\mathrm{SC}_{4} \mathrm{H}_{8}$ ) to acetone solutions of $\mathbf{1}$ at $0^{\circ} \mathrm{C}$ under protective $\mathrm{Ar}$ atmosphere allows to obtain the corresponding complexes $\left[\mathrm{Pt}\left(\mathrm{C}_{6} \mathrm{~F}_{5}\right)(\mathrm{bzq}) \mathrm{L}\right]\left\{\mathrm{L}=\mathrm{PPh}_{3}\right.$ (2), $\mathrm{pyPh}_{2}$ (3), tht (4) $\}$ as yellow solids which precipitate after partial evaporation of the solvent. Complex $\left[\mathrm{Pt}\left(\mathrm{C}_{6} \mathrm{~F}_{5}\right)(\mathrm{bzq})(\mathrm{MeCN})\right]$ (5) is obtaining by dissolving $\mathbf{1}$ in acetonitrile in the same conditions. After two minutes of stirring, the solvent was removed to dryness under vacuum and the resultant yellow solid identified as 5 (See Experimental Section).

The IR spectra of complexes 2-5 confirm the replacement of the acetone in 1, since the $v_{\mathrm{CO}}$ vibration band at $1669 \mathrm{~cm}^{-1}$ is absent; and the bands corresponding to the corresponding ligands incorporated to the coordination sphere of the Pt atoms are now present (see Experimental). The ${ }^{1} \mathrm{H}$ NMR spectra of these complexes also show the signals due to the new ligands, besides the ones attributed to the bzq ligand with the expected relative intensity. The ${ }^{19} \mathrm{~F}$ NMR spectra of 2-5 present the same pattern of three signals corresponding to the pentafluorophenyl ligand. The two ortho-F cause one downfield signal with platinum satellites. At higher field one signal of the meta-F and one of the para-F can be observed. For 2 the ${ }^{31} \mathrm{P}$ NMR spectrum shows a singlet signal with platinum satellites attributable to the phosphorus atom of the $\mathrm{PPh}_{3}$ ligand. All the NMR details are compiled in the Experimental section.

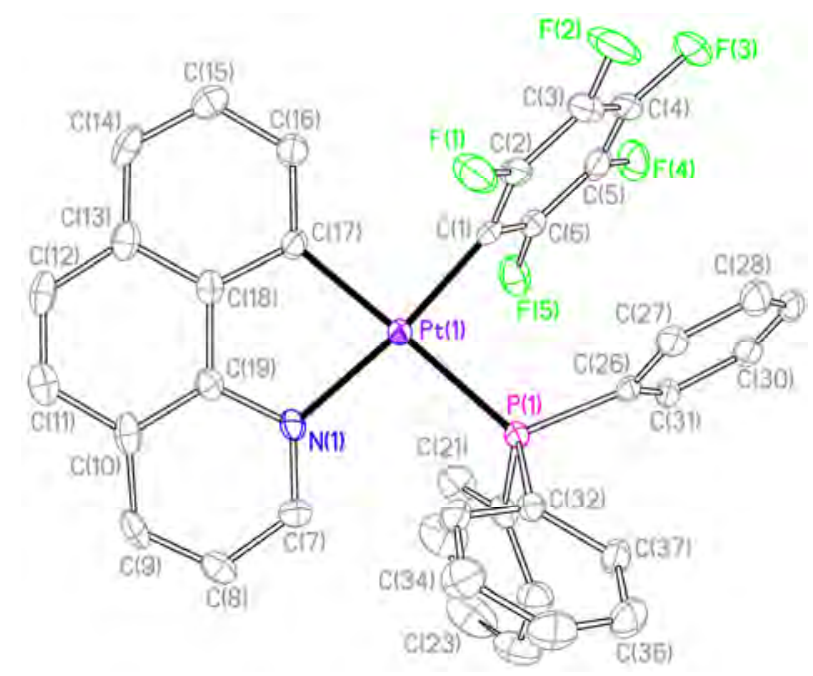

Figure 1. View of the molecular structure of the complex $\left[\mathrm{Pt}\left(\mathrm{C}_{6} \mathrm{~F}_{5}\right)(\mathrm{bzq})\left(\mathrm{PPh}_{3}\right)\right](2)$

Table 1. Selected bond lengths $(\AA)$ and angles $\left(^{\circ}\right)$ for $\left[\mathrm{Pt}\left(\mathrm{C}_{6} \mathrm{~F}_{5}\right)(\mathrm{bzq})\left(\mathrm{PPh}_{3}\right)\right] \cdot 0.2 \mathrm{Me}_{2} \mathrm{CO}\left(2 \cdot 0.2 \mathrm{Me}_{2} \mathrm{CO}\right)$

\begin{tabular}{llll}
$\operatorname{Pt}(1)-\mathrm{C}(1)$ & $2.015(6)$ & $\mathrm{Pt}(1)-\mathrm{C}(17)$ & $2.041(6)$ \\
$\operatorname{Pt}(1)-\mathrm{N}(1)$ & $2.107(5)$ & $\operatorname{Pt}(1)-\mathrm{P}(1)$ & $2.3224(16)$ \\
& & & \\
$\mathrm{C}(1)-\operatorname{Pt}(1)-\mathrm{C}(17)$ & $92.5(2)$ & $\mathrm{C}(1)-\mathrm{Pt}(1)-\mathrm{N}(1)$ & $172.7(2)$ \\
$\mathrm{C}(17)-\mathrm{Pt}(1)-\mathrm{N}(1)$ & $80.6(2)$ & $\mathrm{C}(1)-\mathrm{Pt}(1)-\mathrm{P}(1)$ & $89.36(17)$ \\
$\mathrm{C}(17)-\mathrm{Pt}(1)-\mathrm{P}(1)$ & $176.16(19)$ & $\mathrm{N}(1)-\mathrm{Pt}(1)-\mathrm{P}(1)$ & $97.70(15)$ \\
\hline
\end{tabular}

The structures of complexes 2, $\mathbf{4}$ and $\mathbf{5}$ have been established by $\mathrm{X}$-ray diffraction studies. Figures 1-3 show views of the corresponding complexes and Tables 1-3 list a selection of relevant bond distances and angles. In all three cases, they are square planar complexes, with the bzq ligand coplanar to the metal plane. The pentafluorophenyl ligand is in a trans position with respect to the nitrogen atom of the bzq ligand. As it has been previously observed in other platinum(II) complexes containing the bzq ligand, the complexes establish a supramolecular arrangement through $\pi \cdots \pi$ 
interactions of the bzq aromatic ring system of different moieties which stack in a parallel, head to tail fashion. Thus, in $\mathbf{2}$ four units of the complex $\left[\mathrm{Pt}\left(\mathrm{C}_{6} \mathrm{~F}_{5}\right)(\mathrm{bzq})\left(\mathrm{PPh}_{3}\right)\right]$ are stacked (see Figure S1 in Supplementary information) with interplanar bzq distances of $c a$. $3.4 \AA$, while in $\mathbf{4}$ the asymmetric unit contains three stacked units of the complex $\left[\mathrm{Pt}\left(\mathrm{C}_{6} \mathrm{~F}_{5}\right)\right.$ (bzq)(tht)] (see Figure $2 \mathrm{~b}$ ) with interplanar bzq distances of $c a$. 3.3-3.4 $\AA$. No other $\pi \cdots \pi$ interactions are observed among these groups of four or three units and other adjacent ones. On the other hand, in $\mathbf{5}$ an infinite array of stacked $\left[\mathrm{Pt}\left(\mathrm{C}_{6} \mathrm{~F}_{5}\right)(\mathrm{bzq})(\mathrm{MeCN})\right]$ units is found with similar interplanar bzq distances (see Figure S2 in Supplementary information). This kind of supramolecular arrangement has been found in other complexes with the bzq ligand ${ }^{[17,18,39,53,60,61]}$ or other cyclometalated planar ligands. ${ }^{[32,62]}$ Along with the $\mathrm{H}$ bonding, this kind of $\pi \cdots \pi$ stacking is one of the most important secondary interactions ${ }^{[63-68]}$ in the field of modern supramolecular chemistry, ${ }^{[69-72]}$ playing an important role in processes such as molecular self-assembly and selfrecognition of aromatic entities in the crystal state.

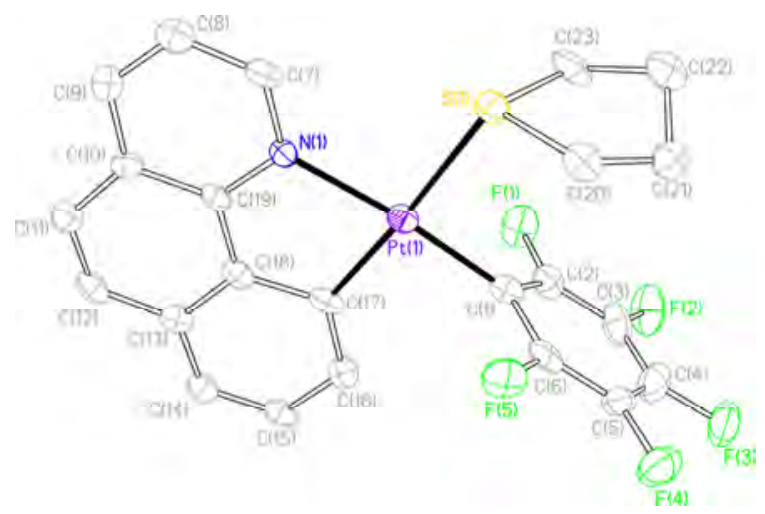

a)

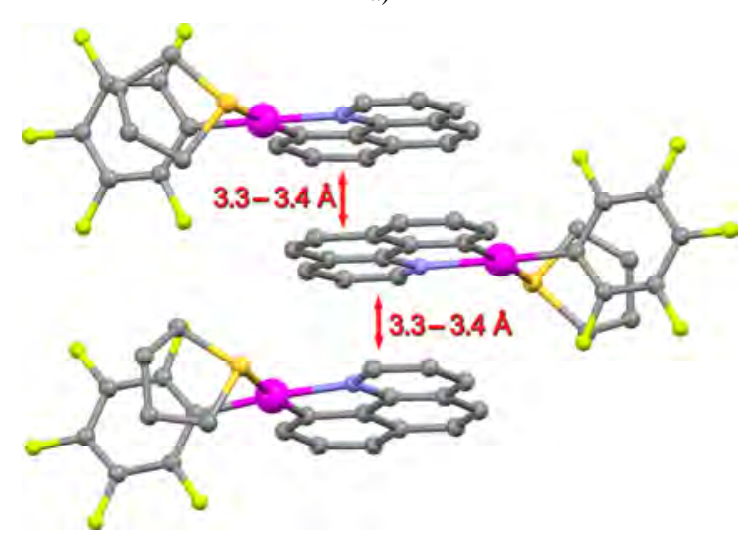

b)

Figure 2. a) View of the molecular structure of the complex $\left[\mathrm{Pt}\left(\mathrm{C}_{6} \mathrm{~F}_{5}\right)(\mathrm{bzq})(\mathrm{tht})\right](4)$. b) Supramolecular arrangement of the three units showing the $\pi \cdots \pi$ stacking

Table 2. Selected bond lengths $(\AA)$ and angles $\left({ }^{\circ}\right)$ for $\left[\mathrm{Pt}\left(\mathrm{C}_{6} \mathrm{~F}_{5}\right)(\mathrm{bzq})(\mathrm{tht})\right] \cdot 2 / 3 \mathrm{CH}_{2} \mathrm{Cl}_{2}\left(4 \cdot 2 / 3 \mathrm{CH}_{2} \mathrm{Cl}_{2}\right)$

\begin{tabular}{llll}
\hline $\mathrm{Pt}(1)-\mathrm{C}(17)$ & $2.000(7)$ & $\mathrm{Pt}(1)-\mathrm{C}(1)$ & $2.003(8)$ \\
$\mathrm{Pt}(1)-\mathrm{N}(1)$ & $2.078(7)$ & $\mathrm{Pt}(1)-\mathrm{S}(1)$ & $2.3719(19)$ \\
& & & \\
$\mathrm{C}(17)-\mathrm{Pt}(1)-\mathrm{C}(1)$ & $91.8(3)$ & $\mathrm{C}(17)-\mathrm{Pt}(1)-\mathrm{N}(1)$ & $82.1(3)$ \\
$\mathrm{C}(1)-\mathrm{Pt}(1)-\mathrm{N}(1)$ & $173.9(3)$ & $\mathrm{C}(17)-\mathrm{Pt}(1)-\mathrm{S}(1)$ & $176.1(2)$ \\
$\mathrm{C}(1)-\mathrm{Pt}(1)-\mathrm{S}(1)$ & $92.1(2)$ & $\mathrm{N}(1)-\mathrm{Pt}(1)-\mathrm{S}(1)$ & $93.98(19)$ \\
\hline
\end{tabular}

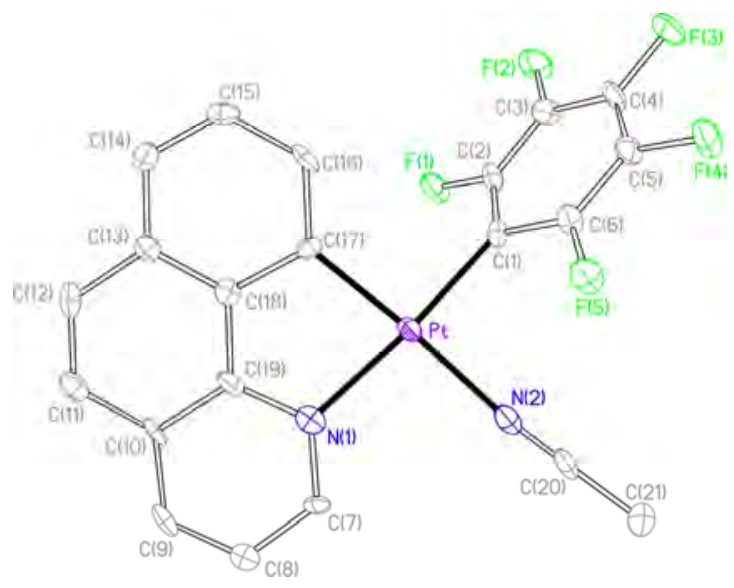

Figure 3. View of the molecular structure of the complex $\left[\mathrm{Pt}\left(\mathrm{C}_{6} \mathrm{~F}_{5}\right)(\mathrm{bzq})(\mathrm{MeCN})\right](5)$

Table 3. Selected bond lengths $(\AA)$ and angles $\quad\left(^{\circ}\right)$ for $\left[\mathrm{Pt}\left(\mathrm{C}_{6} \mathrm{~F}_{5}\right)(\mathrm{bzq})(\mathrm{MeCN})\right](\mathbf{5})$

\begin{tabular}{llll}
\hline Pt-C(17) & $1.993(7)$ & Pt-C(1) & $2.016(8)$ \\
Pt-N(2) & $2.070(7)$ & Pt-N(1) & $2.085(7)$ \\
& & & \\
$\mathrm{C}(17)-\mathrm{Pt}-\mathrm{C}(1)$ & $93.6(3)$ & $\mathrm{C}(17)-\mathrm{Pt}-\mathrm{N}(2)$ & $175.5(3)$ \\
$\mathrm{C}(1)-\mathrm{Pt}-\mathrm{N}(2)$ & $90.3(3)$ & $\mathrm{C}(17)-\mathrm{Pt}-\mathrm{N}(1)$ & $81.6(3)$ \\
$\mathrm{C}(1)-\mathrm{Pt}-\mathrm{N}(1)$ & $173.9(3)$ & $\mathrm{N}(2)-\mathrm{Pt}-\mathrm{N}(1)$ & $94.6(3)$ \\
\hline
\end{tabular}

Reactivity of 1-5 toward $\mathrm{AgClO}_{4}$.Synthesis and characterization of $\left[\left\{\mathrm{Pt}\left(\mathrm{C}_{6} \mathrm{~F}_{5}\right)(\mathrm{bzq}) \mathrm{L}\right\}_{2} \mathrm{Ag}\right] \mathrm{ClO}_{4}\left\{\mathrm{~L}=\mathrm{Me}_{2} \mathrm{CO}(6)\right.$, $\mathrm{PPh}_{3}$ (7), $\operatorname{pyPh}_{2}$ (8), tht (9), MeCN (10)\}

Complexes 1-5 were reacted toward the silver salt $\mathrm{AgClO}_{4}$ with the aim to achieve heterometallic complexes containing $\mathrm{Pt} \rightarrow \mathrm{Ag}$ dative bonds. As mentioned above, it has been previously reported that an anionic nature of the $\mathrm{Pt}(\mathrm{II})$ precursor favours the obtaining of such $\mathrm{Pt} \rightarrow \mathrm{M}$ complexes because the additional electron density borne by the platinum centre that can be donated to the acidic centre. ${ }^{[13]}$ Hence, despite that some neutral Pt(II) precursors have been used, ${ }^{[32,53]}$ most of the success in the preparation of complexes with $\mathrm{Pt} \rightarrow \mathrm{M}$ donor acceptor bonds has been obtained with anionic $\mathrm{Pt}(\mathrm{II})$ complexes as starting materials.

In any case, we have investigated the reactivity of $\mathbf{1 - 5}$ toward $\mathrm{AgClO}_{4}$ in either 1:1 or 2:1 molar ratios. The 1:1 proportion could lead to the preparation of discrete dinuclear $[\mathrm{Pt}-\mathrm{Ag}]^{+}$complexes (Scheme 1A), or polymeric infinite $[\cdots \mathrm{Pt}-\mathrm{Ag}-\mathrm{Pt}-\mathrm{Ag}-\mathrm{Pt} \cdots]^{n+}$ species (Scheme 1B), while the 2:1 molar ratio could lead to the trinuclear [Pt-Ag-Pt] "sandwiches” (Scheme 1C).

Thus, the reaction of complexes 1-5 with $\mathrm{AgClO}_{4}$ in 2:1 molar ratio was carried out in acetone at $0^{\circ} \mathrm{C}$ under $\mathrm{Ar}$ atmosphere and in the absence of light for $30 \mathrm{~min}$. After work up the reaction mixtures, compounds $\left[\left\{\mathrm{Pt}\left(\mathrm{C}_{6} \mathrm{~F}_{5}\right)(\mathrm{bzq}) \mathrm{L}\right\}_{2} \mathrm{Ag}\right] \mathrm{ClO}_{4}\left\{\mathrm{~L}=\mathrm{Me}_{2} \mathrm{CO}(\mathbf{6})\right.$, $\mathrm{PPh}_{3}$ (7), $\mathrm{pyPh}_{2}$ (8), tht (9), MeCN (10)\} were obtained as yellow solids and identified via their analytical and spectroscopic data (see below in Experimental Section) as the corresponding compounds. When the reactions are carried out in the same experimental conditions but in a 1:1 molar ratio, only oily residues could be obtained, which were identified as mixtures of 6-10 and unreacted $\mathrm{AgClO}_{4}$. 


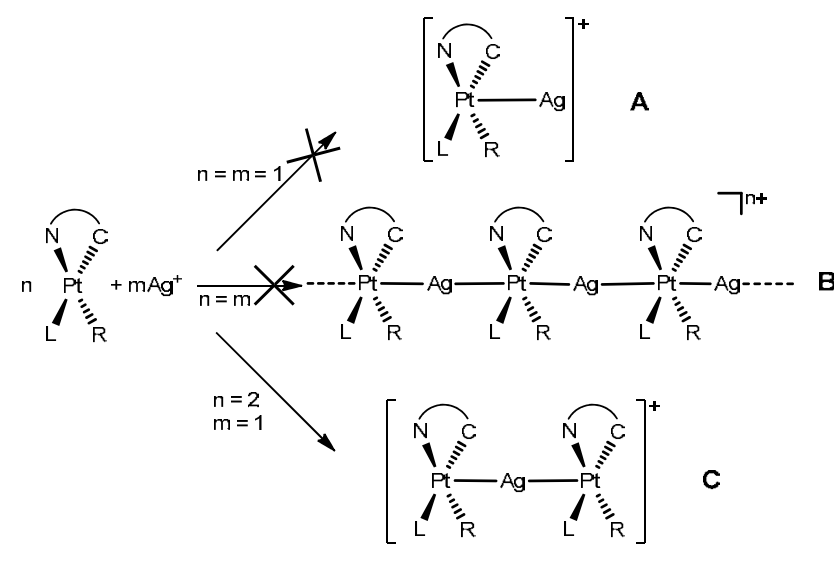

Scheme 1

These results indicate that only the trinuclear complexes depicted in Scheme 1C can be isolated. The stability of the trinuclear complexes toward the ones that could be obtained as a result of 1:1 reactions can be rationalized in the light of the neutral character of the starting $\mathrm{Pt}(\mathrm{II})$ products 1-5. These complexes would not have enough electron density on their basic metal Pt(II) centre to satisfy the requirements of one acidic silver centre, but two Pt(II) have to cooperate to stabilize the trinuclear complex with the formation of two $\mathrm{Pt} \rightarrow \mathrm{Ag}$ bonds with the same $\mathrm{Ag}(\mathrm{I})$. It is noteworthy to remember that, as mentioned above, the similar $\left[\left(\mathrm{C}_{6} \mathrm{~F}_{5}\right)_{2}(\mathrm{bzq}) \mathrm{PtAg}\right]_{\mathrm{x}}$ complex ${ }^{[39]}$ to the one that would be the result of the path depicted in Scheme 1B does exist, but that in this case the starting material is an anionic $\mathrm{Pt}(\mathrm{II})$ complex $\left(\left[\mathrm{Pt}\left(\mathrm{C}_{6} \mathrm{~F}_{5}\right)_{2}(\mathrm{bzq})\right]^{-}\right)$, and thus the $\mathrm{Pt}(\mathrm{II})$ centre seems to be more able to fulfil the electron necessities of the silver centre.

The IR spectra of complexes 6-10 show the presence of two signals assignable to the $\mathrm{ClO}_{4}$ anion, one sharp at $621 \mathrm{~cm}^{-1}$ and another broad at $1095 \mathrm{~cm}^{-1}$. Besides, the expected signals caused by the bzq and corresponding ligands $\mathrm{L}$ can be found.

The ${ }^{1} \mathrm{H}$ NMR spectra of complexes 6-10 show the signals corresponding to the ligands $\mathrm{L}$, besides the ones attributed to the bzq ligand with the expected relative intensity. The ${ }^{19} \mathrm{~F}$ NMR spectra of 6-10 present only one set of signals indicating the equivalence of the pentafluorophenyl groups of the two " $\mathrm{Pt}\left(\mathrm{C}_{6} \mathrm{~F}_{5}\right)$ (bzq) L" subunits. The pattern of the signals is similar to the one described above for complexes 2-5. Finally, for 7 the ${ }^{31} \mathrm{P}$ NMR spectrum shows a singlet signal with platinum satellites attributable to the phosphorus atom of the $\mathrm{PPh}_{3}$ ligand. All the details of these NMR data are compiled in the Experimental section.

Crystal structures of the complexes

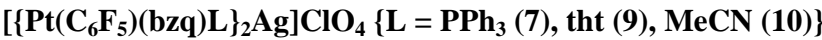

The structures of complexes 7, 9 and $\mathbf{1 0}$ have been established by X-ray diffraction studies. Figures $4-6$ show views of the corresponding complexes and Tables 4-6 list a selection of relevant bond distances and angles.

The determination of the crystal structures confirms that in the solid state these complexes are trinuclear, with a "sandwich" disposition. The two " $\mathrm{Pt}\left(\mathrm{C}_{6} \mathrm{~F}_{5}\right)(\mathrm{bzq}) \mathrm{L}$ " fragments are linked to the silver centre through $\mathrm{Pt} \rightarrow \mathrm{Ag}$ donor acceptor bonds. The $\mathrm{Pt}-\mathrm{Ag}$ distances are 2.823(1) and 2.745(1) $\AA$ for 7, 2.835(1) and 2.841(1) $\AA$ for 9, and 2.792(1) and 2.765(1) $\AA$ in the case of 10. These distances are in the range found for other complexes containing
$\mathrm{Pt} \rightarrow$ Ag bonds. ${ }^{[13,17,23,24,32,34,35,39,54,73-79]}$ The structures of $\mathbf{7 ,} 9$ and $\mathbf{1 0}$ can be compared with the ones described for the two polymorphs of the analogous complex $\left(\mathrm{NBu}_{4}\right)\left[\left\{\mathrm{Pt}\left(\mathrm{C}_{6} \mathrm{~F}_{5}\right)_{2}(\mathrm{bzq})\right\}_{2} \mathrm{Ag}\right],{ }^{[17]}$ also a "sandwich" type complex with a Pt-Ag-Pt bond system similar to the complex described here. As mentioned above, the starting material for $\left(\mathrm{NBu}_{4}\right)\left[\left\{\mathrm{Pt}\left(\mathrm{C}_{6} \mathrm{~F}_{5}\right)_{2}(\mathrm{bzq})\right\}_{2} \mathrm{Ag}\right]$ is anionic, and the resulting trinuclear complex is also anionic. Thus, stronger Pt-Ag bonds, and hence shorter Pt-Ag distances, could be expected in $\left(\mathrm{NBu}_{4}\right)\left[\left\{\mathrm{Pt}\left(\mathrm{C}_{6} \mathrm{~F}_{5}\right)_{2}(\mathrm{bzq})\right\}_{2} \mathrm{Ag}\right]$. The two polymorphs of this anionic "sandwich" show Pt-Ag distances of 2.758(1), 2.684(1), 2.702(1) and 2.690(1) A, in general slightly shorter than the ones found in 7, 9 and 10, but a difference that can also be attributed to steric factors caused by the disposition of the ligands in the complexes or to the intermolecular packing forces. ${ }^{[80]}$

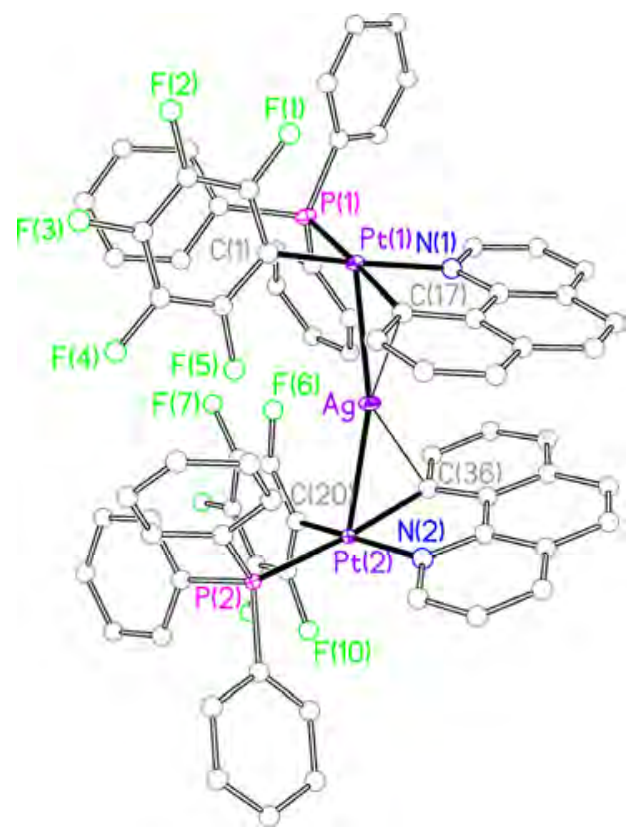

a)

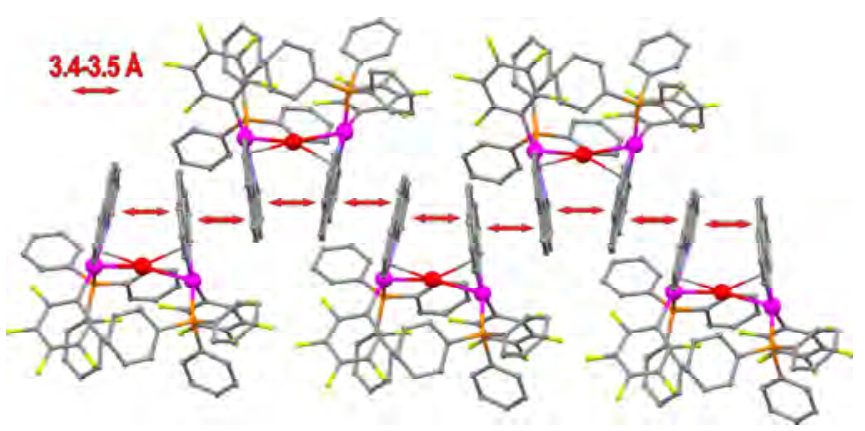

b)

Figure 4. a) View of the molecular structure of the cation of the complex $\left[\left\{\mathrm{Pt}\left(\mathrm{C}_{6} \mathrm{~F}_{5}\right)(\mathrm{bzq})\left(\mathrm{PPh}_{3}\right)\right\}_{2} \mathrm{Ag}\right] \mathrm{ClO}_{4}(7)$. b) Supramolecular arrangement of the infinite $\pi \cdots \pi$ stacking array.

Besides the Pt-Ag bonds, in complexes 7, 9 and $\mathbf{1 0}$ the silver centre also establishes a short $\eta^{1}$ interaction with the $C_{i p s o}$ of the bzq ligands (C(17) and $\mathrm{C}(36)$ in Figures 4-6), with Ag-C distances 2.351(4) and 2.460(3) $\AA$ for 7, 2.347(8) and 2.339(8) $\AA$ for 9 and 2.425(8) y 2.467(8) $\AA$ for 10. These $\eta^{1}$-Ag-C contacts have been previously found in other "(bzq)Pt $\rightarrow A g$ ", ${ }^{17,39]}$ or " $(\mathrm{L}) \mathrm{Pt} \rightarrow \mathrm{Ag}$ " complexes in which $\mathrm{L}$ is another aromatic planar cyclometalated ligand similar to the bzq, such as 2-phenylpyridinate, 2-(2tienyl)pyridinate ${ }^{[23]}$ or ethyl 2,6-diphenylisonicotinate. ${ }^{[32]}$ These $\eta^{1}$ - 
Ag-C interactions are important and, along the $\mathrm{Pt} \rightarrow \mathrm{Ag}$ bonds, contribute to fulfil the electron density requirements of the acidic silver centre. The affinity of this metal for some $\pi$-donor systems is well known, ${ }^{[33,69-72,81-89]}$ being the most usual the $\eta^{1}$ and $\eta^{2}$ coordination modes. Ag-C lines are usually perpendicular to the aromatic planar ring system, which is more or less observed also in 7, 9 and 10, given the geometric limitations imposed by the Pt-Ag bonds. Thus, the angles between the $\mathrm{Ag}-\mathrm{C}$ lines and the perpendicular to the best bzq planes are $15.5(1)^{\circ}$ and $20.3(1)^{\circ}$ for 7 , $13.6(1)^{\circ}$ and $12.1(1)^{\circ}$ for $\mathbf{9}$, and $14.6(2)^{\circ}$ and $18.3(2)^{\circ}$ for $\mathbf{1 0}$.

Table 4. Selected bond lengths $(\AA)$ and angles $\left(^{\circ}\right)$ for $\left[\left\{\mathrm{Pt}\left(\mathrm{C}_{6} \mathrm{~F}_{5}\right)(\mathrm{bzq})\left(\mathrm{PPh}_{3}\right)\right\}_{2} \mathrm{Ag}\right] \mathrm{ClO}_{4} \cdot \mathrm{CH}_{2} \mathrm{Cl}_{2}\left(7 \cdot \mathrm{CH}_{2} \mathrm{Cl}_{2}\right)$

\begin{tabular}{llll}
\hline $\mathrm{Pt}(1)-\mathrm{C}(1)$ & $2.028(4)$ & $\mathrm{Pt}(1)-\mathrm{C}(17)$ & $2.062(4)$ \\
$\mathrm{Pt}(1)-\mathrm{N}(1)$ & $2.106(3)$ & $\mathrm{Pt}(1)-\mathrm{P}(1)$ & $2.3472(10)$ \\
$\mathrm{Pt}(1)-\mathrm{Ag}$ & $2.8225(3)$ & $\mathrm{Pt}(2)-\mathrm{C}(20)$ & $2.024(4)$ \\
$\mathrm{Pt}(2)-\mathrm{C}(36)$ & $2.071(4)$ & $\mathrm{Pt}(2)-\mathrm{N}(2)$ & $2.122(3)$ \\
$\mathrm{Pt}(2)-\mathrm{P}(2)$ & $2.3336(10)$ & $\mathrm{Pt}(2)-\mathrm{Ag}$ & $2.7447(3)$ \\
$\mathrm{Ag}-\mathrm{C}(17)$ & $2.351(4)$ & $\mathrm{Ag}-\mathrm{C}(36)$ & $2.460(3)$ \\
& & & \\
$\mathrm{C}(1)-\mathrm{Pt}(1)-\mathrm{C}(17)$ & $90.64(15)$ & $\mathrm{C}(1)-\mathrm{Pt}(1)-\mathrm{N}(1)$ & $168.49(13)$ \\
$\mathrm{C}(17)-\mathrm{Pt}(1)-\mathrm{N}(1)$ & $80.36(14)$ & $\mathrm{C}(1)-\mathrm{Pt}(1)-\mathrm{P}(1)$ & $91.30(10)$ \\
$\mathrm{C}(17)-\mathrm{Pt}(1)-\mathrm{P}(1)$ & $176.22(10)$ & $\mathrm{N}(1)-\mathrm{Pt}(1)-\mathrm{P}(1)$ & $98.11(9)$ \\
$\mathrm{C}(20)-\mathrm{Pt}(2)-\mathrm{C}(36)$ & $91.66(15)$ & $\mathrm{C}(20)-\mathrm{Pt}(2)-\mathrm{N}(2)$ & $168.58(13)$ \\
$\mathrm{C}(36)-\mathrm{Pt}(2)-\mathrm{N}(2)$ & $80.29(13)$ & $\mathrm{C}(20)-\mathrm{Pt}(2)-\mathrm{P}(2)$ & $89.74(11)$ \\
$\mathrm{C}(36)-\mathrm{Pt}(2)-\mathrm{P}(2)$ & $173.72(10)$ & $\mathrm{N}(2)-\mathrm{Pt}(2)-\mathrm{P}(2)$ & $99.14(9)$ \\
$\mathrm{C}(17)-\mathrm{Ag}-\mathrm{C}(36)$ & $134.78(13)$ & $\mathrm{Pt}(2)-\mathrm{Ag}-\mathrm{Pt}(1)$ & $161.994(13)$ \\
\hline
\end{tabular}

On the other hand, in 7 the silver centre is located relatively close to one of the ortho fluorine atom of each pentafluorophenyl group $(\mathrm{Ag} \cdots \mathrm{F}(5)=2.838(2) \AA$, Ag $\cdots \mathrm{F}(6)=2.691(2) \AA)$, while in $\mathbf{1 0}$ only one $o-\mathrm{F}$ is relatively near the $\mathrm{Ag}$ atom $(\mathrm{Ag} \cdots \mathrm{F}(6)=2.699(10)$ $\AA)$ and in 9, the separation is longer $(\mathrm{Ag} \cdots \mathrm{F}(5)=2.914(5) \AA$, Ag $\cdots F(6)=2.898(4) \AA$ ). This short distances are frequently found in pentafluorophenyl complexes and are considered as secondary contacts that also contribute to complete the electron donation the acidic silver and thus to the final stabilization of the complex. ${ }^{[13]}$

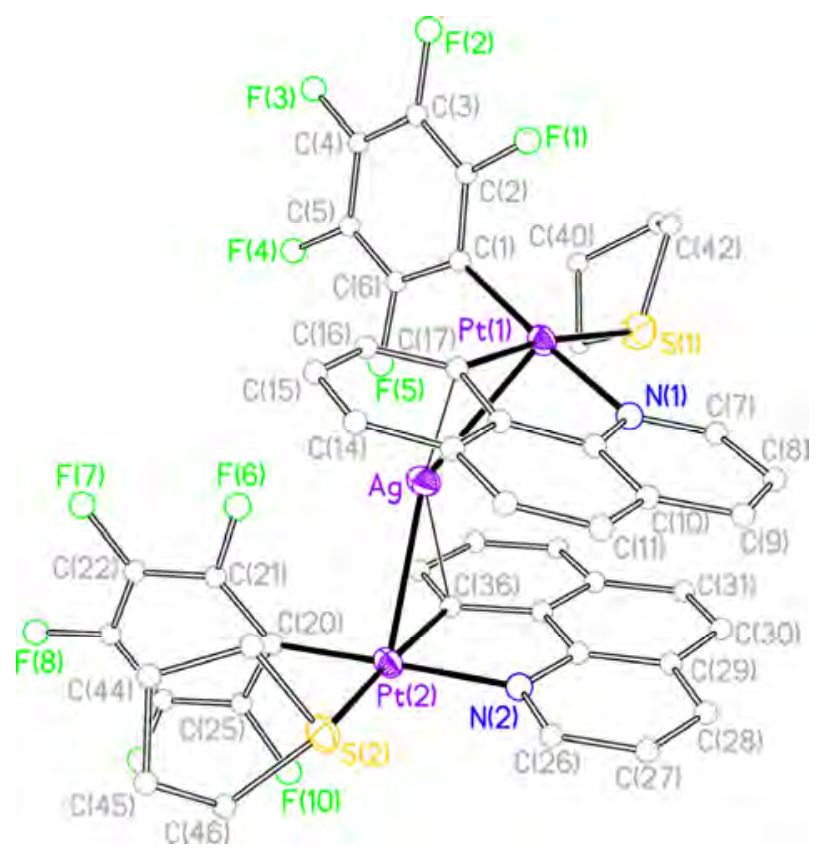

Figure 5. View of the molecular structure of the cation of the complex $\left[\left\{\mathrm{Pt}\left(\mathrm{C}_{6} \mathrm{~F}_{5}\right)(\mathrm{bzq})(\text { tht })\right\}_{2} \mathrm{Ag}\right] \mathrm{ClO}_{4}(\mathbf{9})$
Table 5. Selected bond lengths $(\AA)$ and angles $\left(^{\circ}\right)$ for $\left[\left\{\mathrm{Pt}\left(\mathrm{C}_{6} \mathrm{~F}_{5}\right)(\mathrm{bzq})(\mathrm{tht})\right\}_{2} \mathrm{Ag}\right] \mathrm{ClO}_{4} \cdot 1.5 \mathrm{Me}_{2} \mathrm{CO}\left(\mathbf{9} \cdot 1.5 \mathrm{Me}_{2} \mathrm{CO}\right)$

\begin{tabular}{llll}
\hline $\mathrm{Pt}(1)-\mathrm{C}(1)$ & $2.001(5)$ & $\mathrm{Pt}(1)-\mathrm{C}(17)$ & $2.019(5)$ \\
$\mathrm{Pt}(1)-\mathrm{N}(1)$ & $2.081(5)$ & $\mathrm{Pt}(1)-\mathrm{S}(1)$ & $2.3685(14)$ \\
$\mathrm{Pt}(1)-\mathrm{Ag}$ & $2.8350(5)$ & $\mathrm{Pt}(2)-\mathrm{C}(20)$ & $2.002(5)$ \\
$\mathrm{Pt}(2)-\mathrm{C}(36)$ & $2.020(5)$ & $\mathrm{Pt}(2)-\mathrm{N}(2)$ & $2.092(5)$ \\
$\mathrm{Pt}(2)-\mathrm{S}(2)$ & $2.3686(14)$ & $\mathrm{Pt}(2)-\mathrm{Ag}$ & $2.8410(5)$ \\
$\mathrm{Ag}-\mathrm{C}(17)$ & $2.347(5)$ & $\mathrm{Ag}-\mathrm{C}(36)$ & $2.339(6)$ \\
& & & \\
$\mathrm{C}(1)-\mathrm{Pt}(1)-\mathrm{C}(17)$ & $93.6(2)$ & $\mathrm{C}(1)-\mathrm{Pt}(1)-\mathrm{N}(1)$ & $171.74(19)$ \\
$\mathrm{C}(17)-\mathrm{Pt}(1)-\mathrm{N}(1)$ & $81.6(2)$ & $\mathrm{C}(1)-\mathrm{Pt}(1)-\mathrm{S}(1)$ & $92.72(14)$ \\
$\mathrm{C}(17)-\mathrm{Pt}(1)-\mathrm{S}(1)$ & $171.82(16)$ & $\mathrm{N}(1)-\mathrm{Pt}(1)-\mathrm{S}(1)$ & $92.77(13)$ \\
$\mathrm{C}(20)-\mathrm{Pt}(2)-\mathrm{C}(36)$ & $93.9(2)$ & $\mathrm{C}(20)-\mathrm{Pt}(2)-\mathrm{N}(2)$ & $173.8(2)$ \\
$\mathrm{C}(36)-\operatorname{Pt}(2)-\mathrm{N}(2)$ & $81.6(2)$ & $\mathrm{C}(20)-\mathrm{Pt}(2)-\mathrm{S}(2)$ & $91.98(15)$ \\
$\mathrm{C}(36)-\mathrm{Pt}(2)-\mathrm{S}(2)$ & $173.95(18)$ & $\mathrm{N}(2)-\mathrm{Pt}(2)-\mathrm{S}(2)$ & $92.69(13)$ \\
$\mathrm{C}(36)-\mathrm{Ag}-\mathrm{C}(17)$ & $154.1(2)$ & $\mathrm{Pt}(1)-\mathrm{Ag}-\mathrm{Pt}(2)$ & $149.139(19)$ \\
\hline
\end{tabular}

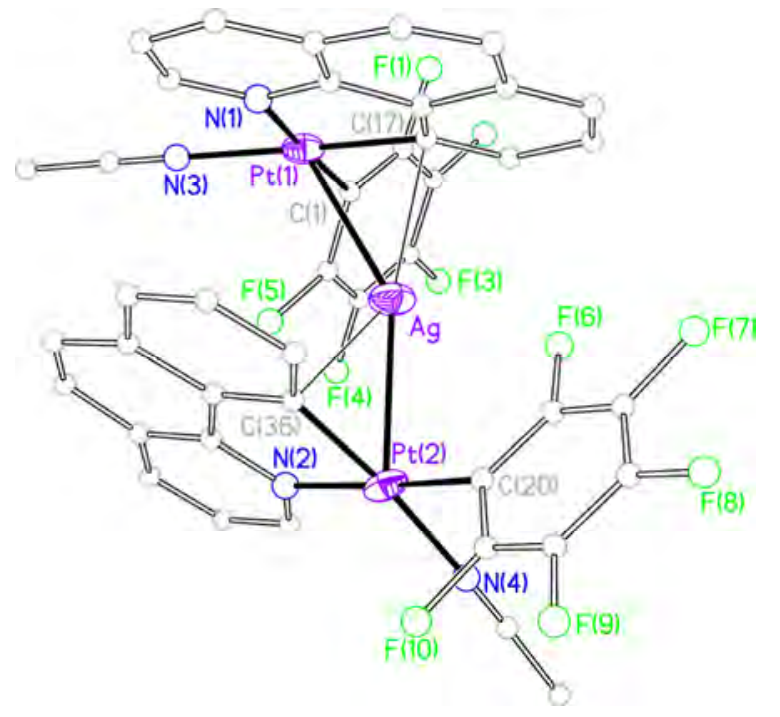

Figure 6. View of the molecular structure of the cation of the complex $\left[\left\{\mathrm{Pt}\left(\mathrm{C}_{6} \mathrm{~F}_{5}\right)(\mathrm{bzq})(\mathrm{MeCN})\right\}_{2} \mathrm{Ag}_{\mathrm{C}} \mathrm{ClO}_{4}(\mathbf{1 0})\right.$

Table 6. Selected bond lengths $(\AA)$ and angles $\left({ }^{\circ}\right)$ for $\left[\left\{\mathrm{Pt}\left(\mathrm{C}_{6} \mathrm{~F}_{5}\right)(\mathrm{bzq})(\mathrm{NCMe})\right\}_{2} \mathrm{Ag}\right] \mathrm{ClO}_{4} \cdot 2.5 \mathrm{CH}_{2} \mathrm{Cl}_{2} \cdot 0.5 n-\mathrm{C}_{6} \mathrm{H}_{14} \quad\left(\mathbf{1 0} \cdot 2.5 \mathrm{CH}_{2} \mathrm{Cl}_{2}\right.$ $\left.\cdot 0.5 n-\mathrm{C}_{6} \mathrm{H}_{14}\right)$

\begin{tabular}{llll}
\hline $\mathrm{Pt}(1)-\mathrm{C}(17)$ & $1.999(7)$ & $\mathrm{Pt}(1)-\mathrm{C}(1)$ & $2.029(8)$ \\
$\mathrm{Pt}(1)-\mathrm{N}(3)$ & $2.061(9)$ & $\mathrm{Pt}(1)-\mathrm{N}(1)$ & $2.072(7)$ \\
$\mathrm{Pt}(1)-\mathrm{Ag}$ & $2.7924(8)$ & $\mathrm{Pt}(2)-\mathrm{C}(20)$ & $2.013(10)$ \\
$\mathrm{Pt}(2)-\mathrm{C}(36)$ & $2.006(7)$ & $\mathrm{Pt}(2)-\mathrm{N}(4)$ & $2.063(7)$ \\
$\mathrm{Pt}(2)-\mathrm{N}(2)$ & $2.096(7)$ & $\mathrm{Pt}(2)-\mathrm{Ag}$ & $2.7646(8)$ \\
$\mathrm{Ag}-\mathrm{C}(17)$ & $2.425(8)$ & $\mathrm{Ag}-\mathrm{C}(36)$ & $2.467(8)$ \\
& & & \\
$\mathrm{C}(17)-\mathrm{Pt}(1)-\mathrm{C}(1)$ & $93.7(3)$ & $\mathrm{C}(17)-\mathrm{Pt}(1)-\mathrm{N}(3)$ & $175.3(3)$ \\
$\mathrm{C}(1)-\mathrm{Pt}(1)-\mathrm{N}(3)$ & $90.9(3)$ & $\mathrm{C}(17)-\mathrm{Pt}(1)-\mathrm{N}(1)$ & $83.1(3)$ \\
$\mathrm{C}(1)-\mathrm{Pt}(1)-\mathrm{N}(1)$ & $176.8(3)$ & $\mathrm{N}(3)-\mathrm{Pt}(1)-\mathrm{N}(1)$ & $92.2(3)$ \\
$\mathrm{C}(20)-\mathrm{Pt}(2)-\mathrm{C}(36)$ & $93.2(3)$ & $\mathrm{C}(20)-\mathrm{Pt}(2)-\mathrm{N}(4)$ & $90.0(3)$ \\
$\mathrm{C}(36)-\mathrm{Pt}(2)-\mathrm{N}(4)$ & $174.4(3)$ & $\mathrm{C}(20)-\mathrm{Pt}(2)-\mathrm{N}(2)$ & $175.1(3)$ \\
$\mathrm{C}(36)-\mathrm{Pt}(2)-\mathrm{N}(2)$ & $81.9(2)$ & $\mathrm{N}(4)-\mathrm{Pt}(2)-\mathrm{N}(2)$ & $94.8(3)$ \\
$\mathrm{C}(17)-\mathrm{Ag}-\mathrm{C}(36)$ & $136.59(19)$ & $\mathrm{Pt}(2)-\mathrm{Ag}-\mathrm{Pt}(1)$ & $147.79(3)$ \\
\hline
\end{tabular}

The Pt-Ag-Pt angles are 161.99(1) ${ }^{\circ}$ in 7, 149.14(2) ${ }^{\circ}$ in 9 and $147.79(3)^{\circ}$ for 10. The Pt-Ag lines are not perpendicular to the square planar environments of the Pt atoms, being the angles to the perpendicular to these planes $32.1(1)^{\circ}$ for $\mathrm{Pt}(1)$ and $24.7(1)^{\circ}$ for $\mathrm{Pt}(2)$ in $7,30.1(1)^{\circ}$ for $\mathrm{Pt}(1)$ and $34.1(1)^{\circ}$ for $\mathrm{Pt}(2)$ in $\mathbf{9}$, and $32.4(2)^{\circ}$ y $32.6(2)^{\circ}$, respectively for $\mathbf{1 0}$. In principle, the best 
disposition for an optimal $\mathrm{Pt} \rightarrow \mathrm{M}$ occurs when the intermetallic line is perpendicular to the $\mathrm{Pt}$ square planar, maximizing the overlapping of the full $5 \mathrm{~d}_{\mathrm{z}} 2 \mathrm{Pt}(\mathrm{II})$ orbital, containing the electron pair donated to form the dative bond, and the empty orbitals of the acidic metal centre. Nevertheless, in this kind of complexes there are some other factors that make the Pt-Ag bond to deviate from this ideal perpendicular disposition. Some of these factors are electronic, such as the $\eta^{1}-\mathrm{Ag}-\mathrm{C}$ interactions or the $o$-F contacts, or steric resulting from the presence of bulky ligands such as $\mathrm{C}_{6} \mathrm{~F}_{5}$ or $\mathrm{PPh}_{3}$ along other less sterically demanding such as bzq, $\mathrm{Me}_{2} \mathrm{CO}$ or MeCN.

In this line, complexes $\mathbf{7 ,} \mathbf{9}$ and $\mathbf{1 0}$ show substantial conformational differences in the relative disposition of the two square planar environments of each structure. In principle, two relative dispositions of the $\mathrm{Pt}$ planes are possible in these "sandwich" trinuclear complexes (see Scheme 2). In the A disposition, the coordination of the two Pt centres takes place in such a way that the positions of the $\mathrm{N}$ and $\mathrm{C}_{i p s o}$ of each bzq ligand are alternate, and thus, also the relative positions of the $\mathrm{L}$ and $\mathrm{C}_{6} \mathrm{~F}_{5}$ ligands of each " $\mathrm{Pt}\left(\mathrm{C}_{6} \mathrm{~F}_{5}\right)$ (bzq) L" fragment. On the other hand, in the $\mathrm{B}$ disposition the relative positions of all the analogous atoms bonded to the Pt in each " $\mathrm{Pt}\left(\mathrm{C}_{6} \mathrm{~F}_{5}\right)$ (bzq)L" fragment coincide. The two conformations have been previously found in similar complexes containing the bzq and $\mathrm{C}_{6} \mathrm{~F}_{5}$ ligands. ${ }^{[17,39]}$ Moreover, it is necessary to take in consideration the possibility of the " $\mathrm{Pt}\left(\mathrm{C}_{6} \mathrm{~F}_{5}\right)(\mathrm{bzq}) \mathrm{L}$ " fragments to turn around the $\mathrm{Pt}-\mathrm{Ag}$ bonds and the variability of the $\mathrm{Pt}-\mathrm{Ag}-\mathrm{Pt}$ angles (see above). For all these reasons, complexes $\mathbf{7 ,} \mathbf{9}$ and $\mathbf{1 0}$ (and $\left.\left(\mathrm{NBu}_{4}\right)\left[\left\{\mathrm{Pt}\left(\mathrm{C}_{6} \mathrm{~F}_{5}\right)_{2}(\mathrm{bzq})\right\}_{2} \mathrm{Ag}\right]^{[17]}\right)$ are very flexible and able to adapt their geometry to the electronic and steric demands mentioned above, as well as the crystal packing effects.

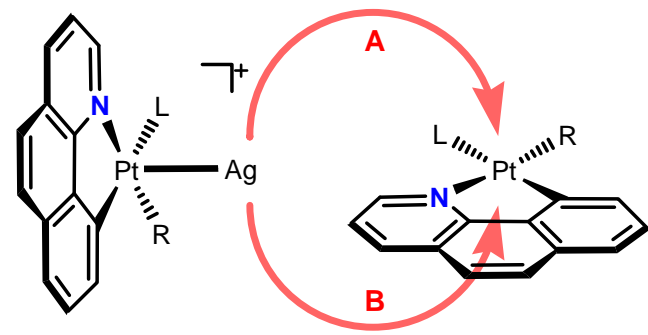

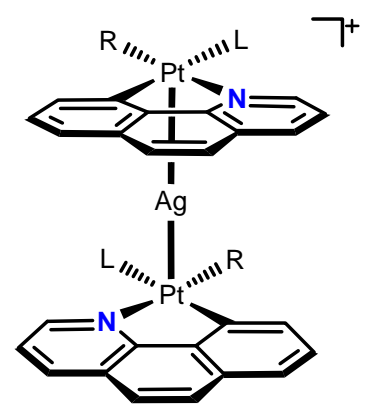

A

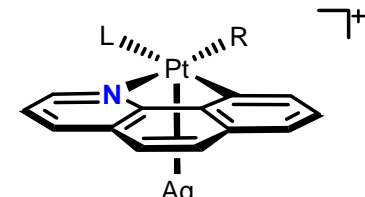

$\mathrm{Ag}$

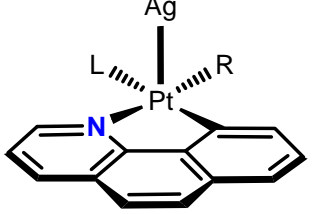

B
Scheme 2

Thus, in complex 7 the dihedral angle between the best Pt square planes is $25.6(1)^{\circ}$, leaning one over the other in such a way that the bzq ligands of the two subunits are almost eclipsed one over the other (torsion angle $\left.\mathrm{N}(1)-\mathrm{Pt}(1)-\mathrm{Pt}(2)-\mathrm{N}(2)=67.4(1)^{\circ}\right)$ with an A conformation (see Scheme 2). This disposition allows the maximum separation between the phenyl groups of the two $\mathrm{PPh}_{3}$ ligands, the bulkiest in the complex. An A type conformation is also observed in 9 , with a dihedral angle of $24.4(1)^{\circ}$ between the two Pt planes, but here the two " $\mathrm{Pt}\left(\mathrm{C}_{6} \mathrm{~F}_{5}\right)$ (bzq)(tht)" fragments are rotated and the torsion angle $\mathrm{N}(1)-\mathrm{Pt}(1)-\mathrm{Pt}(2)-\mathrm{N}(2)$ is only $15.4(1)^{\circ}$. On the other hand, complex 10 shows a B type conformation, probably in order to allow the maximum separation of the most sterically demanding ligands of the complex, in this case the pentafluorophenyl groups.

The study of the supramolecular packing of complexes 7, 9 and 10 has shown an infinite array of cations connected through $\pi \cdots \pi$ interactions of the planar aromatic rings of the bzq ligands, in a similar fashion than the one described above for complexes 2, 4 and 5 and in other complexes previously reported. ${ }^{[17,18,32,39,53,60-62]}$ The interplanar separations are close to $3.4 \AA$, and as example, Figure 4b shows a fragment of this array as found in complex 7.

\section{Reactivity of 1-5 toward $\left[\mathrm{Ag}\left(\mathrm{PPh}_{3}\right)\left(\mathrm{OClO}_{3}\right)\right]$.}

Since the reaction of complexes 1-5 with $\mathrm{AgClO}_{4}$ did not result in the syntheses of neither dinuclear discrete complexes nor polymeric infinite species containing $\mathrm{Pt}-\mathrm{Ag}$ bonds, we tried another silver reagent $\left[\mathrm{Ag}\left(\mathrm{PPh}_{3}\right)\left(\mathrm{OClO}_{3}\right)\right]$. In this complex, the silver centre coordinates to a strong $\mathrm{PPh}_{3}$, which blocks one of its possible coordination positions and contributes to fulfil the electronic requirements of the acidic silver. The aim was the preparation of dinuclear complexes $\left[\mathrm{Pt}(\mathrm{bzq})\left(\mathrm{C}_{6} \mathrm{~F}_{5}\right) \mathrm{LAg}\left(\mathrm{PPh}_{3}\right)\right] \mathrm{ClO}_{4}$, containing a donor acceptor $\mathrm{Pt} \rightarrow \mathrm{Ag}$ bond. This synthetic strategy is well known and has used before with positive results. ${ }^{[13,17,54,79]}$

Thus, complexes 1-5 with $\left[\mathrm{Ag}\left(\mathrm{PPh}_{3}\right)\left(\mathrm{OClO}_{3}\right)\right]$ were reacted in 1:1 molar ratio in acetone at $0^{\circ} \mathrm{C}$ and in an Ar atmosphere. After 30 min of stirring, the acetone is completely removed and the oily residues are treated with $n$-hexane, giving rise to yellow solids that are filtered off and dried in air.

The more significant spectroscopic data of these solids is the presence in the ${ }^{31} \mathrm{P}$ NMR of a singlet signal with platinum satellites, indicating that all the solids correspond to complexes containing a $\mathrm{Pt}-\mathrm{PPh}_{3}$ bond. These spectroscopic data seem to indicate that, at least for complexes 1, 3-5, the $\mathrm{PPh}_{3}$ ligand migrates from the silver centre to the platinum one. In all cases crystals suitable for their analysis by $\mathrm{X}$-ray diffraction were obtained and identified as the complex $\left[\left\{\mathrm{Pt}(\mathrm{bzq})\left(\mathrm{C}_{6} \mathrm{~F}_{5}\right)\left(\mathrm{PPh}_{3}\right)\right\}_{2} \mathrm{Ag}\right] \mathrm{ClO}_{4}(7)$. In the case that the starting material is $\left[\mathrm{Pt}\left(\mathrm{C}_{6} \mathrm{~F}_{5}\right)(\mathrm{bzq})\left(\mathrm{PPh}_{3}\right)\right](2)$, a second signal was also observed in the ${ }^{31} \mathrm{P}$ NMR spectrum of the resulting material. At room temperature this signal is broad and resolves at $-70^{\circ} \mathrm{C}$ in a doublet of doublets, a pattern typical for a phosphorus atoms bonded to a silver centre (silver has two NMR active isotopes, ${ }^{107} \mathrm{Ag}, 51.8 \%$ abundance, and ${ }^{109} \mathrm{Ag}, 48.2 \%$ abundance). Crystals obtained from the crude solid could be also studied by X-ray diffraction, being identified as $\left[\mathrm{Ag}\left(\mathrm{PPh}_{3}\right)_{2}\right]\left(\mathrm{ClO}_{4}\right)$.

On the other hand, when the starting material is $\left[\mathrm{Pt}\left(\mathrm{C}_{6} \mathrm{~F}_{5}\right)(\mathrm{bzq})\left(\mathrm{pyPh}_{2}\right)\right](3)$, it is possible to obtain crystals which have been identified through $\mathrm{X}$-ray diffraction as the dinuclear complex $\quad\left[\left(\mathrm{C}_{6} \mathrm{~F}_{5}\right)(\mathrm{bzq})\left(\mathrm{PPh}_{3}\right) \mathrm{PtAg}\left(\mathrm{pyPh}_{2}\right)\right] \mathrm{ClO}_{4} \quad$ (11), which contains a donor-acceptor $\mathrm{Pt} \rightarrow \mathrm{Ag}$ (see below).

All these results are summarized in Scheme 3. It seems that the migration of the $\mathrm{PPh}_{3}$ ligand from Ag to Pt corresponds to a higher lability of the Pt-O bonds (when $\mathrm{L}=\mathrm{Me}_{2} \mathrm{CO}$ ), $\mathrm{Pt}-\mathrm{N}$ (when $\mathrm{L}=$ $\mathrm{MeCN}$ or $\mathrm{pyPh}_{2}$ ), or Pt-S bonds (when $\mathrm{L}=$ tht), than the Pt-P bonds. The final formation of the trinuclear sandwich $\mathbf{7}$ is probably caused by the final stability of this complex, while the existence of 
$\left[\mathrm{AgL}_{2}\right]^{+}$has only being confirmed for $\mathrm{L}=\mathrm{PPh}_{3}$, but given the presence of signals of the rest of corresponding $L$ in the IR and ${ }^{1} \mathrm{H}$ NMR spectra, it is sensible to assume an overall reaction process as depicted in Scheme 3b.

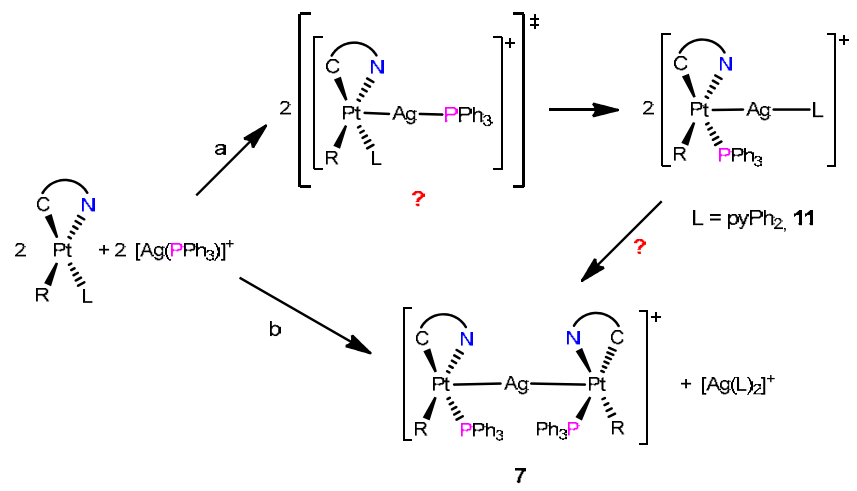

Scheme 3

However, the identification of $\left[\left(\mathrm{C}_{6} \mathrm{~F}_{5}\right)(\mathrm{bzq})\left(\mathrm{PPh}_{3}\right) \mathrm{PtAg}\left(\mathrm{pyPh}_{2}\right)\right] \mathrm{ClO}_{4} \quad$ (11) is interesting. Its existence could indicate that the formation of the trinuclear 7 occurs through a pathway as the one represented in Scheme 3a. For some reason, only in the case of $\mathrm{L}=\mathrm{pyPh}_{2}$, the intermediate compound $\mathbf{1 1}$ could be detected. Apart from the evident electronic reasons, an important difference between the other $\mathrm{L}$ ligands used $\left(\mathrm{Me}_{2} \mathrm{CO}, \mathrm{MeCN}\right.$, tht) and $\mathrm{pyPh}_{2}$ is the size, and thus, the steric hindrance caused by this later. Thus, kinetic reasons could be under the fact that $\mathbf{1 1}$ evolves slower enough than the rest of complexes and some crystals could be formed prior to the complete conversion to 7 .

\section{Crystal structure of the complex $\left[\left(\mathrm{C}_{6} \mathrm{~F}_{5}\right)(\mathrm{bzq})\left(\mathrm{PPh}_{3}\right) \mathrm{PtAg}\left(\mathrm{pyPh}_{2}\right)\right] \mathrm{ClO}_{4}(11)$}

As mentioned above, the crystal structure of complex $\mathbf{1 1}$ has been determined by means of an X-ray diffraction study. Figure 7 shows a view of the complex cation and Table 7 lists a selection of relevant bond distances and angles.

The study confirms the presence of a donor acceptor $\mathrm{Pt} \rightarrow \mathrm{Ag}$ bond in the structure, with an intermetallic distance of 2.8147(1) $\AA$. This distance is similar to those found in complex $\left[\left\{\mathrm{Pt}_{(}\left(\mathrm{C}_{6} \mathrm{~F}_{5}\right)(\mathrm{bzq})\left(\mathrm{PPh}_{3}\right)\right\}_{2} \mathrm{Ag}\right] \mathrm{ClO}_{4}$ (7) (cf. 2.823(1) and 2.745(1) $\AA$ ), which also contains the " $\mathrm{Pt}\left(\mathrm{C}_{6} \mathrm{~F}_{5}\right)(\mathrm{bzq})\left(\mathrm{PPh}_{3}\right)$ " fragment. On the other hand, it is slightly longer that those found in the analogous complexes $\left[\left(\mathrm{C}_{6} \mathrm{X}_{5}\right)_{2}(\mathrm{bzq}) \mathrm{PtAg}\left(\mathrm{PPh}_{3}\right)\right]^{-}(2.728(1) \AA$ for $\mathrm{X}=\mathrm{F}$ and 2.675(3) $\AA$ for $\mathrm{X}=\mathrm{Cl}),{ }^{[17]}$ perhaps because of the anionic nature of these later compounds in comparison with the neutral nature of $\mathbf{1 1}$. Moreover, in the same way as it has been described for complexes 7, 9 and $\mathbf{1 0}$ (see above) and other similar "(bzq)Pt $\rightarrow$ Ag”complexes, ${ }^{[17,}$ 39] the silver centre establish an interaction $\eta^{1}$-Ag-C with the ipso carbon atom of the bzq ligand with a distance Ag-C(17) of 2.293(1) $\AA$. This value is shorter than the one found in 7 (cf. 2.351(4) and 2.460(3) $\AA$ ), 9 (cf. 2.347(8) and 2.339(8) $\AA$ ), and 10 (cf. 2.425(8) and 2.467(8) $\AA$ ), or in complexes $\left[\left(\mathrm{C}_{6} \mathrm{X}_{5}\right)_{2}(\mathrm{bzq}) \operatorname{PtAg}\left(\mathrm{PPh}_{3}\right)\right]^{-}$(2.352(3) $\AA$ for $\mathrm{X}=\mathrm{F}$ and 2.557(5) $\AA$ for $\mathrm{X}=\mathrm{Cl}),{ }^{[17]}$ which seems to indicate a stronger interaction. In fact, the silver centre clearly leans toward the position of the $C_{i p s o}$ of the bzq ligand, being the angle between the $\mathrm{Pt}-\mathrm{Ag}$ line and the perpendicular of the best Pt square plane of $44.6(1)^{\circ}$, a broad value (compare with the analogous angles in 7, 32.1(1) ${ }^{\circ}$ y 24.7(1) ${ }^{\circ}, \mathbf{9}$, $30.1(1)^{\mathrm{o}}$ and $34.1(1)^{\mathrm{o}}$, 10, and $32.4(2)^{\mathrm{o}}$ and $32.6(2)^{\circ}$, $\left[\left(\mathrm{C}_{6} \mathrm{~F}_{5}\right)_{2}(\mathrm{bzq}) \mathrm{PtAg}\left(\mathrm{PPh}_{3}\right)\right]^{-[17]} \quad 34.9(1)^{\circ}, \quad$ or $\left.\left[\left(\mathrm{C}_{6} \mathrm{Cl}_{5}\right)_{2}(\mathrm{bzq}) \mathrm{PtAg}\left(\mathrm{PPh}_{3}\right)\right]^{-[17]} 27.2(1)^{\circ}\right)$, and the Pt-Ag-N(2) angle $146.5(1)^{\circ}$. This disposition "so bent" is probably caused by the steric hindrance caused by two $\mathrm{PPh}_{3}$ and $\mathrm{pyPh}_{2}$ bulky ligands present in 11, which try to separate as much as possible each other. The coordination sphere of the silver centre is completed by the $\mathrm{pyPh}_{2}$ ligand, with a Ag-N(2) distance of 2.190(1) $\AA$, in the usual range for this kind of bonds. ${ }^{\text {[90-95] }}$

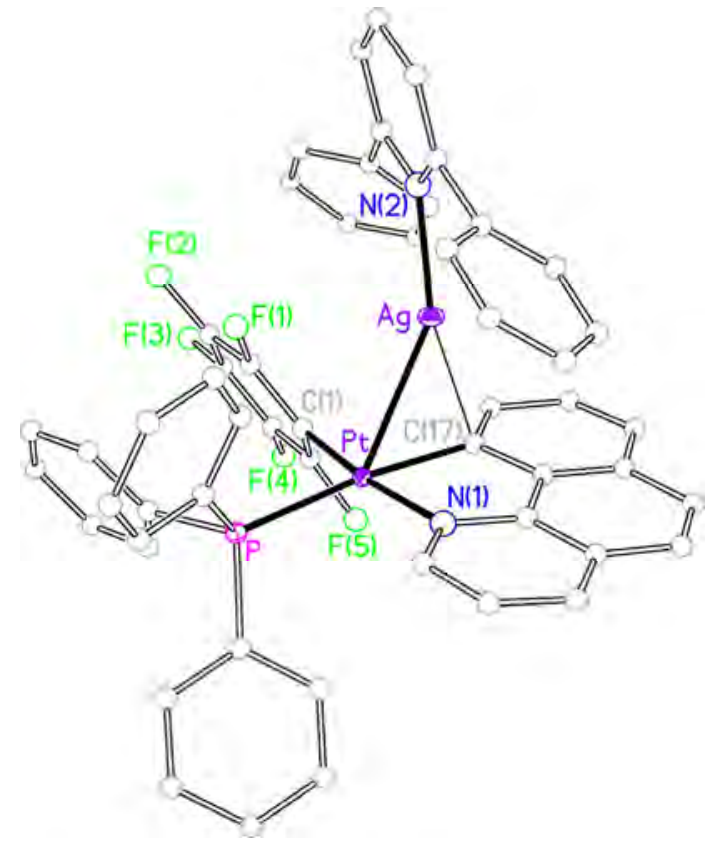

Figure 7. View of the molecular structure of the cation of the complex

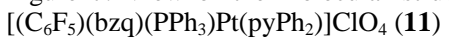

Table 7. Selected bond lengths $(\AA)$ and angles $\left(^{\circ}\right)$ for

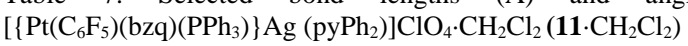

\begin{tabular}{llll} 
Pt-C(1) & $2.0140(13)$ & Pt-C(17) & $2.0633(15)$ \\
Pt-N(1) & $2.1143(11)$ & Pt-P & $2.3286(4)$ \\
Pt-Ag & $2.8147(1)$ & Ag-N(2) & $2.1898(12)$ \\
Ag-C(17) & $2.2929(14)$ & & \\
& & & \\
C(1)-Pt-C(17) & $92.64(6)$ & C(1)-Pt-N(1) & $172.95(5)$ \\
C(17)-Pt-N(1) & $80.42(5)$ & $\mathrm{C}(1)-P t-P$ & $89.90(4)$ \\
C(17)-Pt-P & $173.14(4)$ & N(1)-Pt-P & $97.13(4)$ \\
N(2)-Ag-Pt & $146.48(3)$ & & \\
\hline
\end{tabular}

In this case, complex 11 does not show extended intermolecular interactions through $\pi \cdots \pi$ interactions of the planar aromatic rings of the bzq ligand.

\section{Photophysical properties}

Absorption Spectra and Theoretical Calculations. UV-vis spectra data of compounds 1-11 in solution are summarized in Table S1. Data of the precursor complex $\mathbf{1}$ have been also included for comparative purposes. In dichloromethane solution $\left(10^{-4} \mathrm{M}\right)$, the mononuclear complexes 1-5 exhibit high-energy bands (range 250- $380 \mathrm{~nm}$ ), whose intensity and shapes are typical of ligandcentered transitions ( ${ }^{1} \mathrm{IL}, \mathrm{C}_{6} \mathrm{~F}_{5}$, bzq) somewhat perturbed by platinum coordination (see Figure 8 for complex 2). ${ }^{[39,96,97]}$ In addition, they show a modest shoulder $\left(\varepsilon: 1.0-2.1 \times 10^{3} \mathrm{M}^{-1} \mathrm{~cm}^{-1}\right)$ centered at ca. $400 \mathrm{~nm}$ generally attributed to ${ }^{1} \mathrm{MLCT} /{ }^{1} \mathrm{IL}$ 
Table 8. Photophysical data for compounds 1-5 in the solid state

\begin{tabular}{|c|c|c|c|c|c|}
\hline Compound & & $\lambda_{\text {absorption }} / \mathrm{nm}$ & $\lambda_{\text {exc }} / \mathrm{nm}$ & $\lambda_{\mathrm{em}} / \mathrm{nm}$ & $\tau / \mu \mathrm{s}$ \\
\hline \multirow[b]{2}{*}{1} & $298 K$ & $304,394,412$ (tail to 450 ) & 405 & $467,482,496,578_{\max }$ & $\mathrm{a}$ \\
\hline & $77 \mathrm{~K}$ & & 420 & $504,540_{\max }, 583$ & $\begin{array}{l}204(44 \%), 21.0(56 \%) \text {, at } 504 \mathrm{~nm} \\
212.2(40 \%), 25.6(60 \%) \text {, at } 540 \mathrm{~nm}\end{array}$ \\
\hline \multirow{2}{*}{2} & $298 K$ & $301,388,405$ (tail to 450 ) & 390 & $\begin{array}{c}481_{\max }, 490,515_{\max }, \\
554,599_{\mathrm{sh}}\end{array}$ & $\mathrm{a}$ \\
\hline & $77 \mathrm{~K}$ & & 390 & $\begin{array}{c}479_{\max }, 490,515_{\max } \\
529_{\mathrm{sh}}, 556,596_{\mathrm{sh}}\end{array}$ & $\begin{array}{l}82.0(58 \%), 221.5(42 \%) \text {, at } 479 \mathrm{~nm} \text {, } \\
42.1(28 \%), 107.0(72 \%) \text {, at } 515 \mathrm{~nm}\end{array}$ \\
\hline \multirow[b]{2}{*}{3} & $298 K$ & 302, 408, 427 (tail to 460) & 410 & $497,590_{\max }, 632$ & $\mathrm{a}$ \\
\hline & $77 \mathrm{~K}$ & & 410 & $515,529,555_{\text {máx }}, 590_{\text {sh }}$ & $\begin{array}{c}\text { 158.4(32\%), } 35.8(68 \%) \text {, at } 515 \mathrm{~nm} \\
242.7(25 \%), 40.7(75 \%) \text {, at } 555 \mathrm{~nm}\end{array}$ \\
\hline \multirow[b]{2}{*}{4} & $298 K$ & 303, 387, 402 (tail to 450 ) & 400 & 594, 627 máx & $\mathrm{a}$ \\
\hline & $77 \mathrm{~K}$ & & 400 & $512,552_{\max }, 596_{\mathrm{sh}}$ & $\begin{array}{l}517.5(26 \%), 199.3(74 \%) \text {, at } 512 \mathrm{~nm} \\
440.1(42 \%), 147.0(58 \%) \text {, at } 552 \mathrm{~nm}\end{array}$ \\
\hline \multirow[b]{2}{*}{5} & $298 K$ & $307,390,405$ (tail to 450 ) & 390 & $482,514,580_{\mathrm{sh}}, 632_{\max }$ & $\mathrm{a}$ \\
\hline & $77 \mathrm{~K}$ & & 390 & $512,549_{\max }$ & $\begin{array}{l}366.8(39 \%), 90.7(61 \%) \text {, at } 512 \mathrm{~nm} \\
508.7(36 \%), 84.5(64 \%) \text {, at } 549 \mathrm{~nm}\end{array}$ \\
\hline
\end{tabular}

a) too week emission to be measured.

Table 9. Photophysical data for compounds 6-11 in the solid state

\begin{tabular}{|c|c|c|c|c|c|}
\hline Compound & & $\lambda_{\text {absorption }} / \mathrm{nm}$ & $\lambda_{\text {exc }} / \mathrm{nm}$ & $\lambda_{\mathrm{em}} / \mathrm{nm}[\Phi]$ & $\tau / \mu \mathrm{s}$ \\
\hline \multirow[t]{2}{*}{6} & $298 \mathrm{~K}$ & $\begin{array}{c}\text { 306, 335, } 411 \text { (tail to } \\
550 \text { ) }\end{array}$ & 415 & $515_{\text {sh }}, 581_{\max }$ & $\begin{array}{l}8.2(98 \%), 120.2(2 \%) \text {, at } 515 \mathrm{~nm} \\
6.7(92 \%), 67.0(8 \%) \text {, at } 581 \mathrm{~nm}\end{array}$ \\
\hline & $77 \mathrm{~K}$ & & 415 & $509,597_{\max }$ & 18.7 at $509 \mathrm{~nm}, 16.9$ at $597 \mathrm{~nm}$ \\
\hline \multirow{2}{*}{7} & $298 \mathrm{~K}$ & $\begin{array}{c}305,324,401 \text { (tail to } \\
460 \text { ) }\end{array}$ & 400 & $\begin{array}{l}468_{\mathrm{sh}}, 503,530_{\max }, \\
565 \text { sh }[0.032]\end{array}$ & $\begin{array}{l}23.8(86 \%), 79.1(14 \%) \text { at } 502 \mathrm{~nm} \\
20.1(40 \%), 78.2(60 \%) \text { at } 528 \mathrm{~nm}\end{array}$ \\
\hline & $77 \mathrm{~K}$ & & 400 & $492,591_{\max }$ & $\begin{array}{c}15.6 \text { at } 492 \mathrm{~nm} \\
21.7 \text { (65\%), } 45.5(35 \%) \text {, at } 591 \mathrm{~nm}\end{array}$ \\
\hline \multirow[t]{2}{*}{8} & $298 \mathrm{~K}$ & $\begin{array}{c}303,342,409 \text { (tail to } \\
485)\end{array}$ & 410 & $\begin{array}{c}540_{\mathrm{sh}}, 584_{\max } \\
630_{\mathrm{sh}}\end{array}$ & $\begin{array}{c}8.7 \text { at } 540 \mathrm{~nm} \\
3.1(86 \%), 11.8(14 \%) \text { at } 584 \mathrm{~nm}\end{array}$ \\
\hline & $77 \mathrm{~K}$ & & 410 & $500,638_{\max }$ & 12.7 at $500 \mathrm{~nm}, 14.6$ at $638 \mathrm{~nm}$ \\
\hline \multirow[t]{2}{*}{9} & $298 \mathrm{~K}$ & 300,401 (tail to 460 ) & 400 & $\begin{array}{l}520_{\mathrm{sh}}, 551_{\max } \\
575_{\mathrm{sh}}\end{array}$ & $\begin{array}{l}8.1 \text { at } 520 \mathrm{~nm}, 6.8 \text { at } 551 \mathrm{~nm}, 8.9 \text { at } \\
575 \mathrm{~nm}\end{array}$ \\
\hline & $77 \mathrm{~K}$ & & 400 & 499, 607 $\max$ & 19.4 at $499 \mathrm{~nm}, 33.2$ at $607 \mathrm{~nm}$ \\
\hline \multirow{2}{*}{10} & $298 \mathrm{~K}$ & $\begin{array}{l}\text { 300, } 336,394,408 \\
\quad \text { (tail to } 465 \text { ) }\end{array}$ & 390 & 514,562 max & 1.5 at $514 \mathrm{~nm}, 1.9$ at $562 \mathrm{~nm}$ \\
\hline & $77 \mathrm{~K}$ & & 390 & $500,540_{\mathrm{sh}}, 601_{\max }$ & $\begin{array}{c}14.2 \text { at } 500 \mathrm{~nm}, 19.5 \text { at } 540 \mathrm{~nm}, 15.8 \\
\text { at } 601 \mathrm{~nm}\end{array}$ \\
\hline \multirow{2}{*}{11} & $298 K$ & 302, 397 (tail to 500) & 370 & $\begin{array}{c}490,519_{\max }, 554 \\
{[0.15]}\end{array}$ & $\begin{array}{c}17.6 \text { at } 490 \mathrm{~nm}, 17.9 \text { at } 519 \mathrm{~nm}, 18.0 \\
\text { at } 554 \mathrm{~nm}\end{array}$ \\
\hline & $77 \mathrm{~K}$ & & 370 & $\begin{array}{l}\text { 480, } 492_{\mathrm{sh}}, 509_{\mathrm{sh}}, \\
565_{\max }\end{array}$ & $\begin{array}{l}21.0 \text { at } 480 \mathrm{~nm}, 21.8 \text { at } 492 \mathrm{~nm} \text {, } \\
27.5 \text { at } 509 \mathrm{~nm}, 26.8 \text { at } 565 \mathrm{~nm}\end{array}$ \\
\hline
\end{tabular}

Table 10. Population analysis (\%) of frontier MOs in the ground state for complexes $\left[\mathrm{Pt}_{(}\left(\mathrm{C}_{6} \mathrm{~F}_{5}\right)(\mathrm{bzq}) \mathrm{L}\right]\left(\mathrm{L}=\mathrm{PPh}_{3}(\mathbf{2})\right.$, tht (4), MeCN (5)), $\left[\left(\mathrm{C}_{6} \mathrm{~F}_{5}\right)(\mathrm{bzq})\left(\mathrm{PPh}_{3}\right) \mathrm{PtAg}\left(\mathrm{pyMe}_{2}\right)\right]^{+}(\mathbf{1 1 M e})$ and $\left[\left\{\mathrm{Pt}\left(\mathrm{C}_{6} \mathrm{~F}_{5}\right)(\mathrm{bzq}) \mathrm{L}\right\}_{2} \mathrm{Ag}\right]^{+}(\mathrm{L}=$ tht $(\mathbf{9})$ and $\mathrm{MeCN}(\mathbf{1 0}))$.

\begin{tabular}{|c|c|c|c|c|c|c|c|c|c|c|c|c|}
\hline \multirow[b]{2}{*}{ Comp } & \multicolumn{6}{|c|}{ HOMO } & \multicolumn{6}{|c|}{ LUMO } \\
\hline & $\mathrm{eV}$ & Pt (1/2) & $\mathrm{Ag}$ & $\mathrm{Bzq}$ & $\mathrm{C}_{6} \mathrm{~F}_{5}$ & $\mathrm{~L}$ & $\mathrm{eV}$ & $\mathrm{Pt}(1 / 2)$ & $\mathrm{Ag}$ & $\mathrm{Bzq}$ & $\mathrm{C}_{6} \mathrm{~F}_{5}$ & $\mathrm{~L}$ \\
\hline 2 & -5.68 & 14 & & 84 & 0 & 2 & -1.84 & 4 & & 95 & 0 & 1 \\
\hline 11Me & -8.71 & 12 & 0 & 4 & 77 & 6 & -4.47 & 3 & 9 & 84 & 1 & 3 \\
\hline 4 & -5.71 & 20 & & 79 & 0 & 1 & -1.88 & 4 & & 96 & 0 & 0 \\
\hline 9 & -8.64 & $16 / 16$ & 10 & 55 & 2 & 1 & -4.71 & $1 / 2$ & 12 & 83 & 1 & 1 \\
\hline 5 & -5.59 & 23 & & 75 & 0 & 2 & -1.86 & 4 & & 95 & 0 & 1 \\
\hline 10 & -8.58 & $22 / 2$ & 6 & 56 & 13 & 1 & -4.46 & $2 / 4$ & 17 & 73 & 2 & 2 \\
\hline
\end{tabular}


transitions. UV-vis spectra of complexes 1-5 recorded in different solvents showed a modest solvatochromism (see Figure S3 for complex 2) for the absorption bands, particularly in the lowerenergy spectral region, which is characteristic of charge-transfer (CT) transitions.

The absorption spectra of the heteronuclear (6-11) complexes, are all of them quite similar to those of their precursor (1-5) as much in the solid state as in solution (Tables 8, 9 and S1; Figures 8, S4 and S5 in Supplementary Information). Complexes containing Pt-Ag dative bonds often show a blue shift in the low energy absorption maxima; donation of electron density increases electrophilicity of the Pt centre, lowering the energy of the HOMO, and then raising the energy of the ${ }^{1}$ MLCT absorption bands. ${ }^{[17,39]}$ In complexes 611 little if any shift of the low energy absorption maxima with respect to those of the starting compounds is observed. Similar behavior was previously observed indichloromethane solution of the trinuclear complex, $\left(\mathrm{NBu}_{4}\right)\left[\left\{\mathrm{Pt}(\mathrm{bzq})\left(\mathrm{C}_{6} \mathrm{~F}_{5}\right)_{2}\right\}_{2} \mathrm{Ag}\right]{ }^{[17]}$ which was explained by the partially cleavage of the $\mathrm{Pt}-\mathrm{Ag}$ bond in solution. However, this feature cannot be invoked in the solid state.

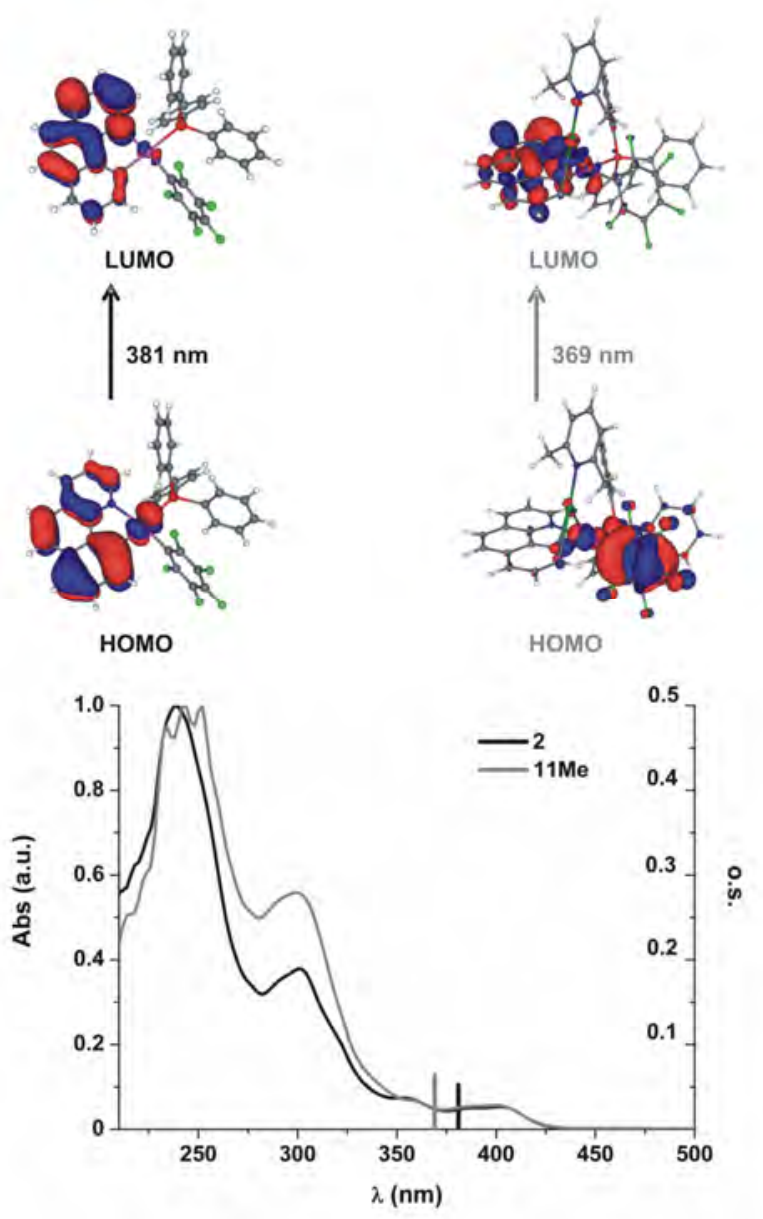

Figure 8. Frontier orbitals plots for complexes 2 and $\mathbf{1 1 M e}$ in $\mathrm{CH}_{2} \mathrm{Cl}_{2}$ obtained by DFT; calculated electronic transitions (bars) and experimental $\mathrm{UV}$-vis spectrum of $\mathbf{2}$ and $\mathbf{1 1}$ in $\mathrm{CH}_{2} \mathrm{Cl}_{2}\left(10^{-4} \mathrm{M}\right)$

To better explain the nature of the lower-energy transitions, time-dependent density functional theory (TD-DFT) calculations were carried out using the hybrid density functionals B3LYP for 2 , 4, 5 and M06 for 9, 10, 11Me (11Me is a model complex derived from complex 11 by replacing the $\mathrm{Ph}$ groups with Me ones in the
$\mathrm{pyPh}_{2}$ ligand in order to simplify the calculation process). The geometric parameters of the optimized $\mathrm{S}_{0}$ structures (Tables S2-S7 in Supplementary Information) agree well with the experimental values. Relevant data about the calculated lower-energy electronic transitions in $\mathrm{CH}_{2} \mathrm{Cl}_{2}$ and frontier molecular orbital (MOs) involved in them are listed in Tables 10 and 11. In the mononuclear complexes, the highest occupied molecular orbital (HOMO) is mostly constructed from orbitals located on the bzq (75\% 5 - 84\% 2) and the platinum center (23\% 5 - 14\% 2). The lower unoccupied molecular orbital (LUMO) is well located on the imine ring ( 95\%). Figure 8 shows that the calculated lowest energy electronic transition in $\mathrm{CH}_{2} \mathrm{Cl}_{2}$ (bars) for compound 2 fits well, within the accuracy of the method, with the experimental absorptions. Calculations indicate that the major contribution to the lowest lying absorption involves the HOMO $\rightarrow$ LUMO (94\%) transition, indicating a remarkable ligand-centered $\left[{ }^{1} \mathrm{IL}, \pi-\pi^{*}\right.$ (bzq)] mixed with some metal-to-ligand charge transfer $\left[{ }^{1} \mathrm{MLCT}\right.$ $\left(5 \mathrm{~d}(\mathrm{Pt}) \rightarrow \pi^{*}(\mathrm{bzq})\right]$ character. Contrary to other benzoquinolate Pt(II) complexes described up to now, ${ }^{[39,96,97]}$ no ligand-to-ligand charge transfer [ ${ }^{1} \mathrm{~L}$ 'LCT, $\mathrm{Ar}_{\mathrm{f}} \rightarrow$ bzq or $\mathrm{L} \rightarrow$ bzq] transitions are involved in this absorption. On view of the data showed in Tables 10 and 11 and Figures S4 and S5 the same assignments can be made for the lowest lying absorption of compounds $\mathbf{4}$ and $\mathbf{5}$, but in these cases the transition shows a little higher ${ }^{1}$ MLCT character. The blue shift observed in the calculated lowest energy transition of $2(381 \mathrm{~nm})$ in relation to that of the other mononuclear complexes (382 nm 4, $386 \mathrm{~nm} \mathrm{5)} \mathrm{can} \mathrm{be} \mathrm{due} \mathrm{to} \mathrm{the} \mathrm{lower} \mathrm{level} \mathrm{of}$ energy of the $\mathrm{d} \pi(\mathrm{Pt})$ orbitals because of the electron-withdrawing character of $\mathrm{PPh}_{3}$ with respect to tht and MeCN ligands, ${ }^{[98-101]}$ since no significant contribution of the L ligands to the frontier orbitals have been observed.

Table 11. Selected singlet excited states calculated by TD-DFT for complexes 2, 4, 5 and $\mathbf{9 , 1 0}$ and $11 \mathrm{Me}$ in $\mathrm{CH}_{2} \mathrm{Cl}_{2}$ solution.

\begin{tabular}{c|c|c|c}
\hline Compound & $\begin{array}{c}\lambda_{\text {exc }} \text { (calc.) } \\
\text { [nm] }\end{array}$ & o.s. & $\begin{array}{c}\text { Transition } \\
\text { (Percentage contribution) }\end{array}$ \\
\hline $\mathbf{2}$ & 381.2 & 0.0524 & HOMO $\rightarrow$ LUMO (94.4\%) \\
$\mathbf{1 1 M e}$ & 369.3 & 0.0695 & HOMO $\rightarrow$ LUMO (94.5\%) \\
\hline $\mathbf{4}$ & 382.2 & 0.0610 & HOMO $\rightarrow$ LUMO (94.0\%) \\
$\mathbf{9}$ & 405.2 & 0.0516 & HOMO $\rightarrow$ LUMO (94.5\%) \\
\hline $\mathbf{5}$ & 386.9 & 0.0577 & HOMO $\rightarrow$ LUMO (94.8\%) \\
$\mathbf{1 0}$ & 385.3 & 0.0342 & HOMO $\rightarrow$ LUMO (85.8\%); \\
\hline
\end{tabular}

Calculations performed on the trinuclear complexes $\mathbf{9}$ and $\mathbf{1 0}$ show that the HOMO is constructed from orbitals located on the bzq ( 55\%) and the platinum centers (32\% 9, 24\% 10) and with less weight from silver $(10 \% 9,6 \% 10)$ and $\mathrm{C}_{6} \mathrm{~F}_{5}$ orbitals $(2 \% \mathbf{9}$, $13 \% 10)$. The LUMO is well located on the imine ring (83\% 9, $73 \% \mathbf{1 0})$ and the silver atom $(12 \% \mathbf{9}, 17 \% \mathbf{1 0})$. Therefore, it seems that formation of two Pt-Ag bonds decreases the weight of the bzq and increases the metallic character $(\mathrm{Pt} / \mathrm{Ag})$ of the HOMO and LUMO orbitals with respect to those of the starting complexes.

In the dinuclear complex 11Me, the HOMO is mainly constructed from orbitals located on the $\mathrm{C}_{6} \mathrm{~F}_{5}$ (77\%) and the platinum center (12\%) with no contribution of the AOs of the silver atom and just a marginal contributions of bzq orbitals (4\%). The LUMO is well located on the imine ring (84\%) with only a small metallic character (3\% Pt, 9\% Ag). Therefore, the formation of a $\mathrm{Pt}-\mathrm{Ag}$ bond in 11Me changes dramatically the composition of the frontier orbitals, specially that of the HOMO, decreasing the weight of the bzq orbitals and increasing those of the electronwithdrawing $\mathrm{C}_{6} \mathrm{~F}_{5}$ group, as it was observed previously for the 
dinuclear complexes $\left[\left\{\mathrm{Pt}(\mathrm{bzq})\left(\mathrm{C}_{6} \mathrm{~F}_{5}\right)_{2}\right\} \mathrm{AgL}\right]\left(\mathrm{L}=\mathrm{PPh}_{3}\right.$, tht $) .{ }^{[39]}$ Taking into account that the lowest energy electronic absorption of each one of these heteronuclear complexes is associated with a HOMO $\rightarrow$ LUMO transition (Table 11) it could be ascribed to ${ }^{1} \mathrm{ILCT} /{ }^{1} \mathrm{MM}$ 'LCT $\left[\pi-\pi^{*}(\mathrm{bzq})\right] /\left(\mathrm{d} / \mathrm{s}(\mathrm{Pt}, \mathrm{Ag}) \rightarrow \pi^{*}(\mathrm{bzq})\right]$ for 9 and 10 and to mixed ${ }^{1} \mathrm{MLCT} /{ }^{1} \mathrm{~L}{ }^{\prime} \mathrm{LCT}$ [MLCT $\left(5 \mathrm{~d}(\mathrm{Pt}) \rightarrow \pi^{*}(\mathrm{bzq})\right] /\left[\mathrm{L}{ }^{\prime} \mathrm{LCT}, \mathrm{Ar}_{\mathrm{f}} \rightarrow \mathrm{bzq}\right]$ for $11 \mathrm{Me}$. Therefore, the formation of $\mathrm{Pt}-\mathrm{Ag}$ bonds lead to the stabilization of the HOMO and LUMO orbitals and to the change of the electronic transitions nature; however, the effect in the transitions energy is small and not always the transitions are shifted to higher energies.

The diffuse reflectance UV-vis spectra of complexes 1-11 in the solid state exhibit a similar profile to those in solution (see Figure S6 for 1-5). Therefore, the same origin of the absorptions can be presumed. This fact indicate that the $\pi \cdots \pi$ interactions observed in the solid state (Figures 2b, 4b, S1 and S2) have a very small effect, if any, in the lowest energy absorption maxima except for complex 3 , in which such absorption appears red shifted in relation to that of the other mononuclear complexes.

Emission spectra. Complexes 1-5 are scarcely emissive in the solid state at room temperature but becomes brightly emissive at 77 $\mathrm{K}$ exhibiting an asymmetric yellow emission whose excitation spectrum resembles the absorption one (see Table 8 and Figure 9 for complex 4). Emission lifetimes are rather long and always fit to two components, as observed in many benzoquinolate Pt(II) complexes. ${ }^{[97]}$ Therefore the phosphorescent emission can be ascribed to an admixture of ${ }^{3} \mathrm{IL} /{ }^{3} \mathrm{MLCT}$ excited states, probably with a remarkable ${ }^{3} \mathrm{IL}$ character, especially for complex $\mathbf{2}$.

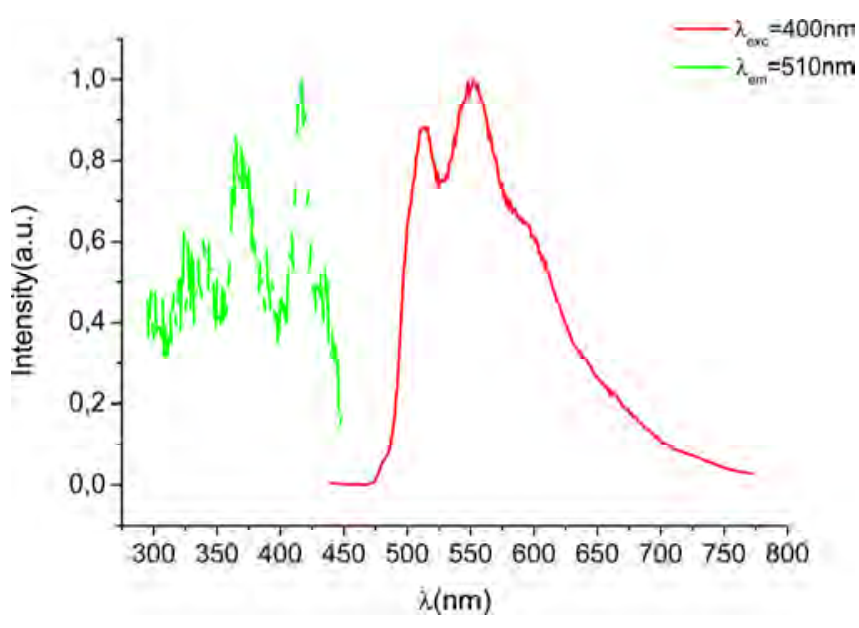

Figure 9. Normalized excitation and emission spectra of $\mathbf{4}$ in the solid state at $77 \mathrm{~K}$

It is worth to note that at $298 \mathrm{~K}$ only compound 2 results moderately emissive (see Figure 10a). The emission (and excitation) profile of $\mathbf{2}$ is similar to those observed at $77 \mathrm{~K}$ and arise mainly from excited states originated in the monomer species. However in compounds 1, 3-5 the weak emission seems to come from barely emissive aggregates. ${ }^{[18,}$ 102] By contrast, the heteronuclear compounds 6-11 are emissive in the solid state at room temperature (see Figure 10b) showing that in a general trend, the presence of $\mathrm{Pt}-\mathrm{Ag}$ dative bonds in the heteronuclear compounds enhance dramatically the emission intensity when it is compared to that of their Pt(II) starting complexes.

At $298 \mathrm{~K}$ the heteronuclear compounds 6-11 (see Table 9 and

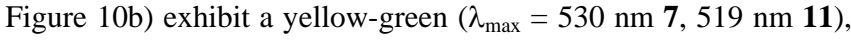

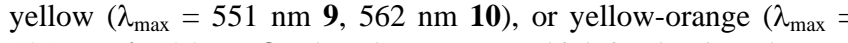

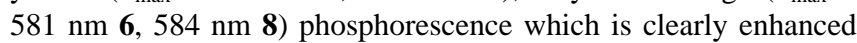
upon cooling to $77 \mathrm{~K}$.

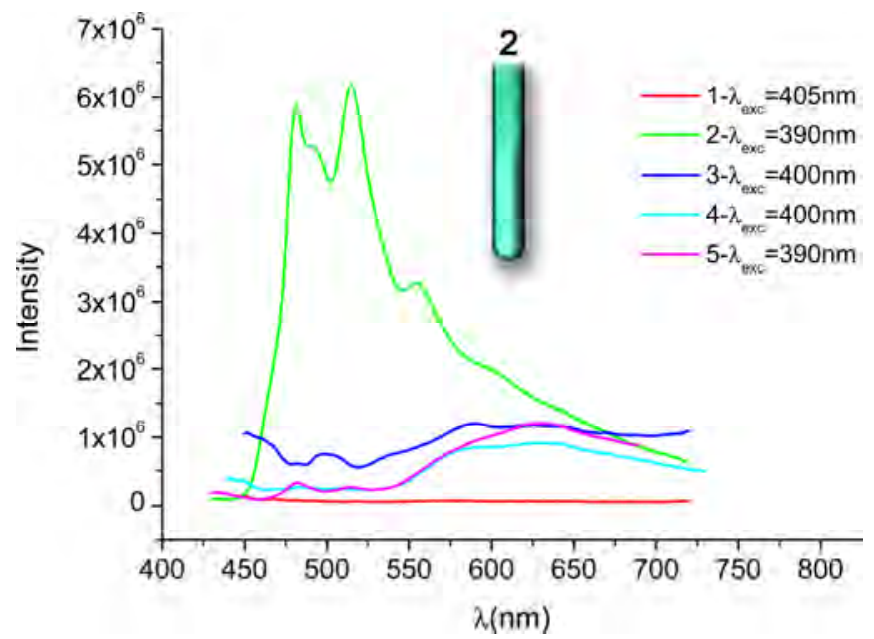

a)

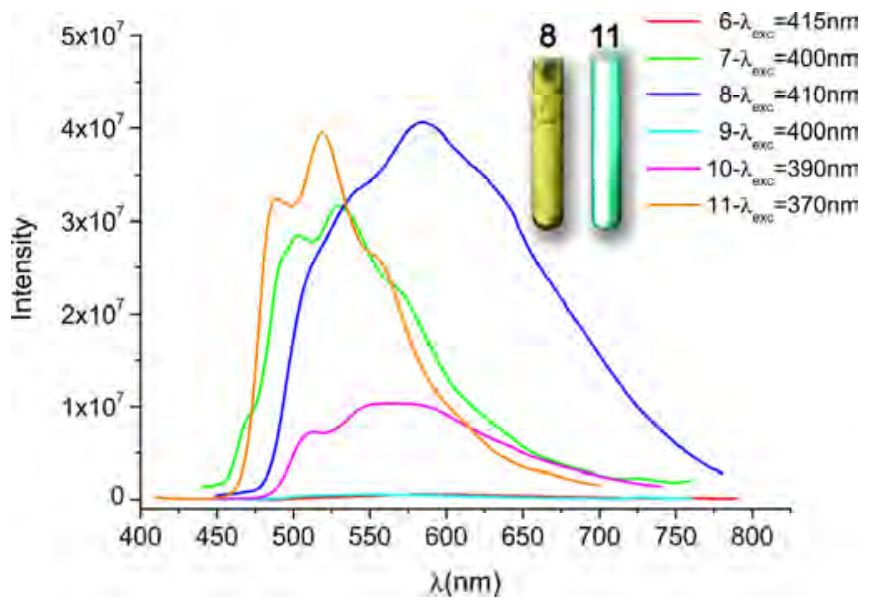

b)

Figure 10. a) Unnormalized emission spectra of 1-5 in the solid sate at 298 K. b) Unnormalized emission spectra of 6-11 in the solid state at $298 \mathrm{~K}$; insets: compounds $\mathbf{2 , 8}$ and $\mathbf{1 1}$ at $298 \mathrm{~K}$ upon excitation at $\lambda=365 \mathrm{~nm}$ )

Compounds $\mathbf{7}$ and 11, which contain the fragment "Pt(bzq) $\left(\mathrm{C}_{6} \mathrm{~F}_{5}\right)\left(\mathrm{PPh}_{3}\right)$ " show emission spectra very similar one to another at 298K (Figure 10b) and also at 77K (Figure 11). Taking into account the TD-DFT calculations performed for compound $11 \mathrm{Me}$ and the emission behaviour described previously for complex $\left[\left\{\mathrm{Pt}(\mathrm{bzq})\left(\mathrm{C}_{6} \mathrm{~F}_{5}\right)_{2}\right\} \mathrm{Ag}\left(\mathrm{PPh}_{3}\right)\right]{ }^{[39]}$ the emission band observed at $298 \mathrm{~K}$ can be mainly arise from a mixed ${ }^{3} \mathrm{MLCT} /{ }^{3} \mathrm{~L}$ 'LCT excited state. At $77 \mathrm{~K}$ the emission clearly resolves into two bands: a weaker high energy (HE) emission at $\sim 490 \mathrm{~nm}$, and an intense broad asymmetrical low energy (LE) band $\left(\lambda_{\max }=\right.$ 591nm 7, $565 \mathrm{~nm} \mathrm{11)} \mathrm{with} \mathrm{its} \mathrm{maximum} \mathrm{clearly} \mathrm{red-shifted} \mathrm{with}$ respect to that at $298 \mathrm{~K}$. The HE emission which resembles the emission of the corresponding precursor can be tentatively assigned to ${ }^{3} \mathrm{IL} /{ }^{3} \mathrm{MLCT}$ excited state.

The emission spectra of the trinuclear compounds 6, 8-10 at 77 K show a similar profile to that of compound 7, but with their

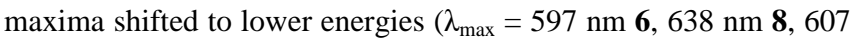

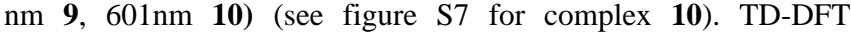
calculations performed on complexes $\mathbf{9}$ and $\mathbf{1 0}$ showed an important contribution of the metallic orbitals $(\mathrm{Pt} / \mathrm{Ag})$ to the frontier orbitals along with a small one of the $\mathrm{C}_{6} \mathrm{~F}_{5}$ orbitals. 
Because of that it seems plausible to assign the more intense LE band observed in the spectra of $\mathbf{8 - 1 0}$ to a ${ }^{3} \mathrm{MM} \mathrm{M}^{\prime} \mathrm{LCT} /{ }^{3} \mathrm{ILCT}$ emissive state.

Complexes 1-11 are emissive in rigid matrix of $\mathrm{CH}_{2} \mathrm{Cl}_{2}\left(10^{-3} \mathrm{M}\right)$ at $77 \mathrm{~K}$ (Table S8 in Supplementary Information). Compounds 1-5 show several emissions upon excitation in the range 350-400 nm. They show low intensity bands between 460-525 nm and a high intensity asymmetric band centered at ca. $600 \mathrm{~nm}$ with tail to 700 nm. 2-Me-THF glassy solutions of 1-5 show similar profiles. At low concentration $\left(10^{-5} \mathrm{M}\right)$, the low energy band shows similar energy and lifetime, but different profile to that in the solid state at 77K (see figures 9 and 12 for complex 4), which could be attributed to a bigger deformation of the excited state geometry in $\mathrm{CH}_{2} \mathrm{Cl}_{2}$ at $77 \mathrm{~K}$. The increasing intensity of the low energy band with respect to the higher energy ones with the concentration (range $10^{-5} \mathrm{M}$ to $10^{-3} \mathrm{M}$ ) added to the red shift of its maximum (see Figure 12 for compound 4), suggest that emissive ground-state aggregates due to close $\pi \cdots \pi$ intermolecular contacts could be not completely excluded at higher concentration. The emission spectra of the heteronuclear compounds in rigid matrix of $\mathrm{CH}_{2} \mathrm{Cl}_{2}\left(10^{-3} \mathrm{M}\right.$,

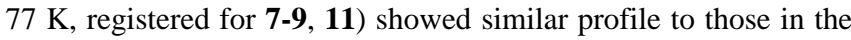
solid state at $77 \mathrm{~K}$; therefore the same origin can be presumed for these bands.

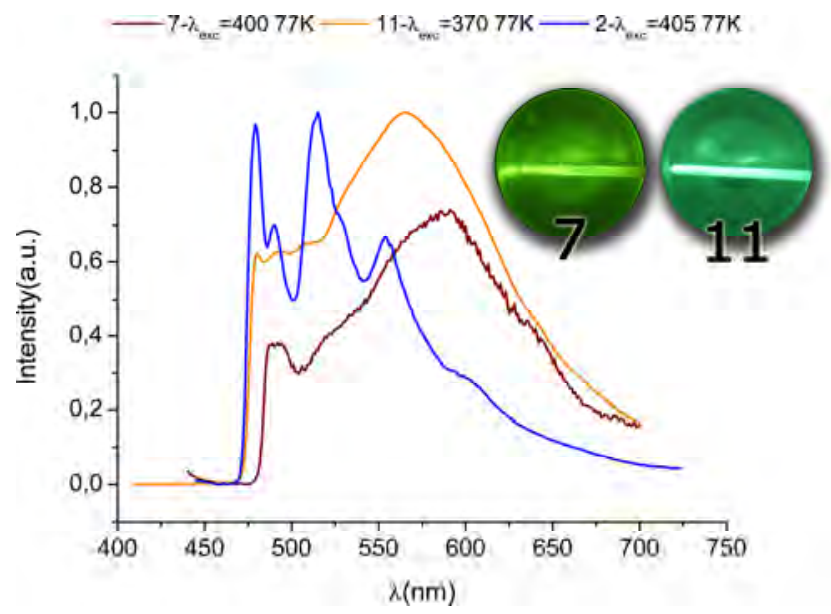

Figure 11. Normalized emission spectra of 2, $\mathbf{7}$ and $\mathbf{1 1}$ in the solid state at 77K. Inset: images of the compounds 7 and $\mathbf{1 1}$ at $77 \mathrm{~K}$ upon excitation at $\lambda=$ $365 \mathrm{~nm}$

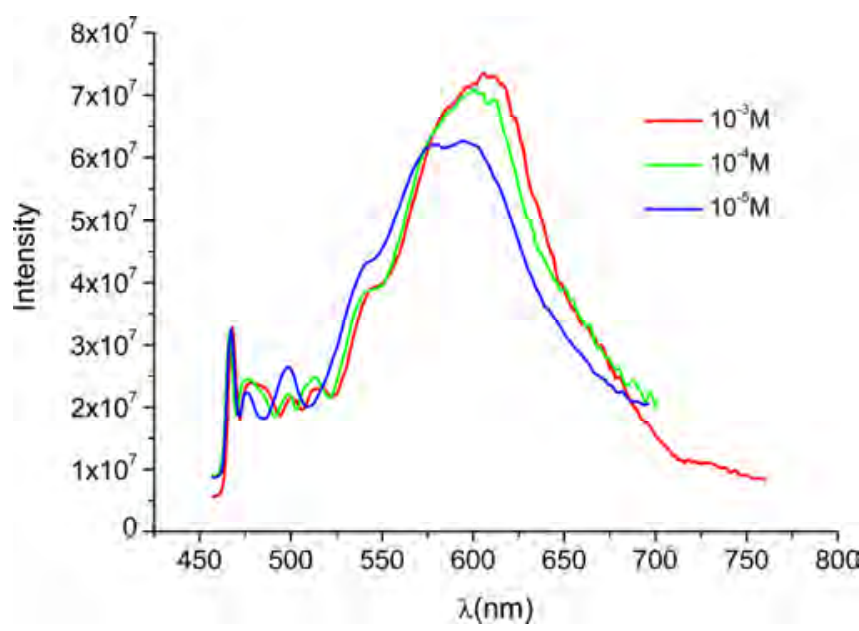

Figure 12. Emission spectra of 4 in $\mathrm{CH}_{2} \mathrm{Cl}_{2}(77 \mathrm{~K})$ when $\lambda_{\text {exc }}=400 \mathrm{~nm}$.

\section{Conclusions}

Despite its neutral character, complexes $\left[\mathrm{Pt}\left(\mathrm{C}_{6} \mathrm{~F}_{5}\right)(\mathrm{bzq}) \mathrm{L}\right](\mathrm{L}=$ $\mathrm{Me}_{2} \mathrm{CO}, \mathrm{PPh}_{3}, \mathrm{pyPh}_{2}$, tht, MeCN\} have proven to be suitable precursors for the preparation of complexes containing $\mathrm{Pt}-\mathrm{Ag}$ dative bonds. The bzq ligand seems to play an important role in the stabilization of the heteropolynuclear complexes formed in a twofold way. Firstly, being a strong field ligand raises the energy of the $d_{z}{ }^{2}$ platinum orbital and favours the formation of stronger $\mathrm{Pt} \rightarrow \mathrm{Ag}$ dative bonds. On the other hand, in these complexes the silver centres establishes short $\eta^{1}$ interactions with the $C_{i p s o}$ of the bzq ligand which contribute to fulfil the electron density requirements of the acidic silver centre. Nevertheless, only trimetallic "sandwich" complexes $\left[\left\{\mathrm{Pt}\left(\mathrm{C}_{6} \mathrm{~F}_{5}\right)(\mathrm{bzq}) \mathrm{L}\right\}_{2} \mathrm{Ag}\right]^{+}$can be prepared, even if other Pt:Ag ratios are used. Therefore, it seems that the silver centre "needs" to be surrounded by two subunits $\left[\mathrm{Pt}\left(\mathrm{C}_{6} \mathrm{~F}_{5}\right)(\mathrm{bzq}) \mathrm{L}\right]$, with their corresponding $\mathrm{Pt}-\mathrm{Ag}$ and $\mathrm{Ag}-\mathrm{C}_{\text {ipso }}$ interactions, which contrasts with the complexes $\left[\left\{\mathrm{Pt}(\mathrm{bzq})\left(\mathrm{C}_{6} \mathrm{~F}_{5}\right)_{2}\right\} \operatorname{Ag}(\mathrm{L})\right]$ and $\left[\left\{\mathrm{Pt}(\mathrm{bzq})\left(\mathrm{C}_{6} \mathrm{~F}_{5}\right)_{2}\right\} \mathrm{Ag}\right]_{\mathrm{x}}$, in which the Pt:Ag ratio is $1: 1$, obtained with the anionic $\left[\mathrm{Pt}(\mathrm{bzq})\left(\mathrm{C}_{6} \mathrm{~F}_{5}\right)_{2}\right]^{-}$in which in principle the Pt has an excess of electron density. Only in one case, a 1:1 product $\left[\left(\mathrm{C}_{6} \mathrm{~F}_{5}\right)(\mathrm{bzq})\left(\mathrm{PPh}_{3}\right) \mathrm{PtAg}\left(\mathrm{pyPh}_{2}\right)\right] \mathrm{ClO}_{4}$ (11) have been observed, its relative stability caused by the presence of bulkier ligands that slow down the transformation into $\left[\left\{\mathrm{Pt}\left(\mathrm{C}_{6} \mathrm{~F}_{5}\right)(\mathrm{bzq})\left(\mathrm{PPh}_{3}\right)\right\}_{2} \mathrm{Ag}\right] \mathrm{ClO}_{4}(7)$.

Moreover, complexes $\left[\left\{\mathrm{Pt}\left(\mathrm{C}_{6} \mathrm{~F}_{5}\right)(\mathrm{bzq}) \mathrm{L}\right\}_{2} \mathrm{Ag}\right]^{+}$have shown to be flexible and able to adapt their geometry (to some extent) to the bulkiness of the ancillary L ligands, preserving at the same time the $\mathrm{Pt}-\mathrm{Ag}$ and $\mathrm{Ag}-\mathrm{C}_{i p s o}$ interactions.

The photophysical properties of these complexes have been discussed with the aid of TD-DFT calculations on several compounds $\left(2,4,5,9,10,11 \mathrm{Me}\right.$ in $\left.\mathrm{CH}_{2} \mathrm{Cl}_{2}\right)$. While in the mononuclear complexes the lower lying absorption bands are ascribed to mixed [ ${ }^{1} \mathrm{IL}, \pi-\pi^{*}$ (bzq)]/ [ ${ }^{1} \mathrm{MLCT}\left(5 \mathrm{~d}(\mathrm{Pt}) \rightarrow \pi^{*}(\mathrm{bzq})\right]$ transitions in the heteronuclear compounds, the formation of $\mathrm{Pt}-\mathrm{Ag}$ bonds changes the character of the transition to ${ }^{1} \mathrm{ILCT} /{ }^{1} \mathrm{MM}$ 'LCT $\left[\pi-\pi^{*}(\mathrm{bzq})\right] /\left(\mathrm{d} / \mathrm{s}(\mathrm{Pt}, \mathrm{Ag}) \rightarrow \pi^{*}(\mathrm{bzq})\right]$ for the trinuclear complexes and to mixed ${ }^{1} \mathrm{MLCT} /{ }^{1} \mathrm{~L}$ 'LCT [MLCT $\left(5 \mathrm{~d}(\mathrm{Pt}) \rightarrow \pi^{*}(\mathrm{bzq})\right] /[\mathrm{L}$ 'LCT, $\left.\mathrm{Ar}_{\mathrm{f}} \rightarrow \mathrm{bzq}\right]$ for the dinuclear complex 11. However, although the formation of the Pt-Ag bonds perturbs the frontier orbitals, it does not always shift the HOMO $\rightarrow$ LUMO transition to higher energies. With the exception of compound 2, the mononuclear complexes are not emissive in the solid sate at room temperature. However the heteronuclear compounds are. All compounds become brightly emissive in the solid state at $77 \mathrm{~K}$. The main phosphorescent emission has been tentatively associated in all the compounds with a transition similar in character to their lowest lying absorption.

\section{Experimental Section}

Physical Measurements: C, H and N analyses, conductivity, IR and NMR spectra were performed as described elsewhere. ${ }^{[16]}$ Diffuse reflectance UVvis (DRUV) spectra were recorded on a Thermo electron corporation evolution 600 spectrophotometer equipped with a Praying Mantis integrating sphere. The solid samples were homogeneously diluted with silica. The mixtures were placed in a homemade cell equipped with quartz window. Steady-state photoluminescence spectra were recorded on a JobinYvon Horiba Fluorolog FL-3-11 Tau 3 spectrofluorimeter using slit width of $3 \mathrm{~nm}$ for both excitation and emission. Phosphorescence lifetimes were recorded with a Fluoromax phosphorimeter accessory containing a UV xenon flash tube with a flash rate between 0.05 and $25 \mathrm{~Hz}$. Phase shift and modulation were recorded over the frequency range of $0.1-100 \mathrm{MHz}$. 
Nanosecond lifetimes were recorded with an IBH 5000F Coaxial nanosecond flashlamp. The lifetime data were fitted using the Jobin-Yvon software package and the Origin Pro 8 program. The quantum efficiency was determined using a Quantaurus quantum yield equipment from Hamamatsu model C11347-11.

Preparations: Literature methods were used to prepare the starting material $\left[\mathrm{Pt}\left(\mathrm{C}_{6} \mathrm{~F}_{5}\right)(\mathrm{bzq})\left(\mathrm{Me}_{2} \mathrm{CO}\right)\right](\mathbf{1}){ }^{[60]}$

Caution!: Perchlorate salts of metal complexes with organic ligands are potentially explosive. Only small amounts of material should be prepared and these should be handled with great caution.

Preparation of $\left[\operatorname{Pt}\left(\mathrm{C}_{6} \mathrm{~F}_{5}\right)(\mathbf{b z q}) \mathrm{L}\right]\left\{\mathrm{L}=\mathbf{P P h}_{3}\right.$ (2), $\mathrm{pyPh}_{2}$ (3), tht (4)\}. To a solution of [Pt(bzq) $\left.\left(\mathrm{C}_{6} \mathrm{~F}_{5}\right)\left(\mathrm{Me}_{2} \mathrm{CO}\right)\right]$ (1) $(0.200 \mathrm{~g}, 0.335 \mathrm{mmol})$ in $\mathrm{Me}_{2} \mathrm{CO}$ $(10 \mathrm{~mL})$ at $0^{\circ} \mathrm{C}$ and under Ar atmosphere, $0.335 \mathrm{mmol}$ of $\mathrm{L}\left(\mathrm{L}=\mathrm{PPh}_{3}\right.$, $0.0879 \mathrm{~g} ; \mathrm{pyPh}_{2}, 0.0775 \mathrm{~g}$; tht, $30 \mu \mathrm{L}$ ) was added. After $2 \mathrm{~min}$ of stirring the solution was concentrated until ca. $2 \mathrm{~mL}$. The yellow precipitate which appeared was filtered off, washed with $n$-hexane $(10 \mathrm{~mL})$ and air dried.

[Pt $\left.\left(\mathbf{C}_{6} \mathbf{F}_{5}\right)(\mathbf{b z q})\left(\mathbf{P P h}_{3}\right)\right]$ (2). 0.242 g, 90\% yield. $\mathrm{C}_{37} \mathrm{H}_{22} \mathrm{~F}_{5} \mathrm{NPPt}$ (801.63) calcd.: C 55.37, H 2.89, N 1.75; found: C 55.32, H 2.90, N 1.79. IR ( $\left.\mathrm{cm}^{-1}\right)$ : 1498 (w), 1458 (w), 1433 (w), 1096 (w, vpph3), 1058 (w), 955 (m), 804 (m, $\mathrm{C}_{6} \mathrm{~F}_{5}$, X-sensitive vibr.), ${ }^{[103]} 693(\mathrm{w}), 529(\mathrm{~m}), 509(\mathrm{~m}) . \Lambda_{\mathrm{M}}\left(\mathrm{Me}_{2} \mathrm{CO}\right)=4.17$ $\Omega^{-1} \mathrm{~cm}^{2} \mathrm{~mol}^{-1}$. ${ }^{1} \mathrm{H}$ NMR $\left(\mathrm{Me}_{2} \mathrm{CO}-\mathrm{d}_{6}\right.$, $295 \mathrm{~K}$. See scheme 4 for the atom numbering scheme of the bzq ligand): $\delta 8.55\left(\mathrm{H} 4, \mathrm{dd},{ }^{3} J_{\mathrm{H}(4), \mathrm{H}(3)}=8.08 \mathrm{~Hz}\right.$, $\left.{ }^{4} J_{\mathrm{H}(4), \mathrm{H}(2)}=1.25 \mathrm{~Hz}\right), 8.33\left(\mathrm{H} 2, \mathrm{dd},{ }^{3} J_{\mathrm{H}(2), \mathrm{H}(3)}=5.35 \mathrm{~Hz},{ }^{4} J_{\mathrm{H}(2), \mathrm{H}(4)}=1.07 \mathrm{~Hz}\right.$, $\left.{ }^{3} J_{\mathrm{P} t \mathrm{H}(2)}=26.85 \mathrm{~Hz}\right), 7.93\left(\mathrm{H} 5, \mathrm{~d},{ }^{3} J_{\mathrm{H}(5), \mathrm{H}(6)}=8.72 \mathrm{~Hz}\right), 7.78(\mathrm{H} 6, \mathrm{~m}$, overlapped with $6 \mathrm{H}-\mathrm{m}$-Ph and H7), 7.78 (H7, m, overlapped with $6 \mathrm{H}-\mathrm{m}-\mathrm{Ph}$ and $\mathrm{H6}$ ), 7.78 (6H-m-Ph, m, overlapped with $\mathrm{H6}$ and H7), 7.51 (3H-p-Ph, $\left.\mathrm{m}, J_{\mathrm{H} p-\mathrm{Hm}}=7.50, J_{\mathrm{H} p-\mathrm{Ho}}=1.60\right), 7.43$ (H8, m, overlapped with $\left.6 \mathrm{H}-\mathrm{o}-\mathrm{Ph}\right), 7.43$ (6H-o-Ph, m, overlapped with $\mathrm{H} 8), 7.23\left(\mathrm{H} 3, \mathrm{dd},{ }^{3} J_{\mathrm{H}(3), \mathrm{H}(4)}=8.06 \mathrm{~Hz}\right.$, $\left.{ }^{3} J_{\mathrm{H}(3), \mathrm{H}(2)}=5.37 \mathrm{~Hz}\right), 7.00\left(\mathrm{H} 9, \mathrm{dd},{ }^{3} J_{\mathrm{H}(9), \mathrm{H}(8)}=7.26 \mathrm{~Hz},{ }^{3} J_{\mathrm{H}(9), \mathrm{H}(7)}=6.22 \mathrm{~Hz}\right.$, $\left.{ }^{3} J_{\mathrm{Pt}, \mathrm{H}(9)}=52.01 \mathrm{~Hz}\right) \cdot{ }^{19} \mathrm{~F} \mathrm{NMR}\left(\mathrm{Me}_{2} \mathrm{CO}-\mathrm{d}_{6}, 295 \mathrm{~K}\right), \delta-118.50\left(o-\mathrm{F},{ }^{3} J_{\mathrm{F}, \mathrm{Pt}}=\right.$ $508.6 \mathrm{~Hz}), 167.94$ (m-F, br m), -168.37 (p-F). ${ }^{31} \mathrm{P}$ NMR $\left(\mathrm{Me}_{2} \mathrm{CO}-\mathrm{d}_{6}, 295\right.$ $\mathrm{K}), \delta 28.05\left(\mathrm{~s}, J_{\mathrm{P}, \mathrm{Pt}}=1982.2 \mathrm{~Hz}\right)$

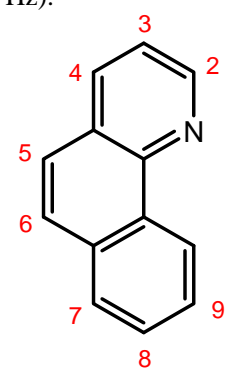

Scheme 4

[Pt( $\left.\left(\mathbf{C}_{6} \mathbf{F}_{5}\right)(\mathbf{b z q})(\mathbf{p y P h})\right]$ (3). 0.220 g, 85\% yield. $\mathrm{C}_{36} \mathrm{H}_{21} \mathrm{~F}_{5} \mathrm{~N}_{2} \mathrm{Pt}$ (771.65) calcd.: C 56.03, H 2.74, N 3.63; found: C 55.88, H 2.86, N 3.52. IR $\left(\mathrm{cm}^{-1}\right)$ : 1497 (w), 1448 (m), 1435 (w), 1056 (w), 951 (m), 793 (m, C $\mathrm{F}_{5}, \mathrm{X}-$ sensitive vibr.), ${ }^{[103]} 696\left(\mathrm{~m}, \mathrm{v}_{\mathrm{pypph} 2}\right) \cdot \Lambda_{\mathrm{M}}\left(\mathrm{Me}_{2} \mathrm{CO}\right)=5.66 \Omega^{-1} \mathrm{~cm}^{2} \mathrm{~mol}^{-1} .{ }^{1} \mathrm{H}$ $\operatorname{NMR}\left(\mathrm{Me}_{2} \mathrm{CO}-\mathrm{d}_{6}, 295 \mathrm{~K}\right), \delta 8.67\left(\mathrm{H} 2, \mathrm{~m},{ }^{3} J_{\mathrm{H}(2) \mathrm{H}(3)}=5.30 \mathrm{~Hz}\right), 8.64(\mathrm{H} 4, \mathrm{~d}$, $\left.{ }^{3} J_{\mathrm{H}(4), \mathrm{H}(3)}=8.10 \mathrm{~Hz},{ }^{4} J_{\mathrm{H}(4), \mathrm{H}(2)}=1.20 \mathrm{~Hz}\right), 8.26\left(4 \mathrm{H}-\mathrm{o}-\mathrm{Ph}, \mathrm{m},{ }^{3} J_{\mathrm{Ho}, \mathrm{Hm}}=7.09\right.$ $\mathrm{Hz},{ }^{4} J_{\mathrm{H}, \mathrm{Hp}}=1.50 \mathrm{~Hz}$ ), 7.98-7.86 (m, overlapped signals of $2 \mathrm{H}-m-\mathrm{py}$ and $\mathrm{H}-$ p-py), 7.85 (H5, d, $\left.{ }^{3} J_{\mathrm{H}(5), \mathrm{H}(6)}=8.80 \mathrm{~Hz}\right), 7.78\left(\mathrm{H} 6, \mathrm{~d},{ }^{3} J_{\mathrm{H}(6), \mathrm{H}(5)}=8.80 \mathrm{~Hz}\right)$, $7.73(\mathrm{H} 3$, m, overlapped with $\mathrm{H} 2$ and $\mathrm{H} 4), 7.56\left(\mathrm{H} 7, \mathrm{~d},{ }^{3} \mathrm{~J}_{\mathrm{H}(7), \mathrm{H}(8)}=7.97 \mathrm{~Hz}\right)$, $7.53\left(4 \mathrm{H}-m-\mathrm{Ph}, \mathrm{m},{ }^{3} J_{\mathrm{H} m, \mathrm{Ho}}=7.45 \mathrm{~Hz},{ }^{3} J_{\mathrm{H} m, \mathrm{H} p}=1.40 \mathrm{~Hz}\right), 7.46(2 \mathrm{H}-p-\mathrm{Ph}, \mathrm{tt}$, $\left.{ }^{3} J_{\mathrm{H} p, \mathrm{Hm}}=7.28 \mathrm{~Hz},{ }^{4} J_{\mathrm{H} p, \mathrm{Ho}}=1.30 \mathrm{~Hz}\right), 7.25\left(\mathrm{H} 8, \mathrm{dd},{ }^{3} J_{\mathrm{H}(8), \mathrm{H}(7)}=7.66 \mathrm{~Hz}\right.$, $\left.{ }^{3} J_{\mathrm{H}(8), \mathrm{H}(9)}=7.35 \mathrm{~Hz}\right), 6.89\left(\mathrm{H} 9, \mathrm{dd},{ }^{3} J_{\mathrm{H}(9), \mathrm{H}(8)}=7.35 \mathrm{~Hz},{ }^{3} J_{\mathrm{H}(9), \mathrm{Pt}}=74.1 \mathrm{~Hz}\right)$. ${ }^{19} \mathrm{~F}$ NMR $\left(\mathrm{CD}_{2} \mathrm{Cl}_{2}, 295 \mathrm{~K}\right), \delta-119.04\left(o-\mathrm{F},{ }^{3} J_{\mathrm{F}, \mathrm{Pt}}=513 \mathrm{~Hz}\right),-166.61(p-\mathrm{F}$, t), 167.75 ( $m-\mathrm{F}$, br m).

[Pt( $\left.\mathbf{C}_{6} \mathbf{F}_{5}\right)$ (bzq)(tht)] (4). 0.214 g, $98 \%$ yield. $\mathrm{C}_{23} \mathrm{H}_{16} \mathrm{~F}_{5} \mathrm{NSPt}$ (628.52) calcd.: C 43.95, H 2.57, N 2.23, S 5.10; found: C 44.08, H 2.32, N 2.33, S 5.10. IR ( $\left.\mathrm{cm}^{-1}\right)$ : $1501(\mathrm{~m}), 1451(\mathrm{~m}), 1437(\mathrm{~m}), 1267$ (w, $\left.\mathrm{v}_{\mathrm{SC}}\right), 1255$ (w, $v_{\mathrm{SC}}$ ), 1061 (m), 951 (s), 798 (m, $\mathrm{C}_{6} \mathrm{~F}_{5}$, X-sensitive vibr.). ${ }^{[103]} \Lambda_{\mathrm{M}}\left(\mathrm{Me}_{2} \mathrm{CO}\right)=0.2$
$\Omega^{-1} \mathrm{~cm}^{2} \mathrm{~mol}^{-1} .{ }^{1} \mathrm{H}$ NMR $\left(\mathrm{Me}_{2} \mathrm{CO}-\mathrm{d}_{6}, 295 \mathrm{~K}\right), \delta 9.35\left(\mathrm{H} 2, \mathrm{dd},{ }^{3} J_{\mathrm{H}(2), \mathrm{H}(3)}=5.24\right.$ $\left.\mathrm{Hz},{ }^{4} J_{\mathrm{H}(2), \mathrm{H}(4)}=1.31 \mathrm{~Hz},{ }^{3} J_{\mathrm{H}(2), \mathrm{Pt}}=23.4 \mathrm{~Hz}\right), 8.70\left(\mathrm{H} 4, \mathrm{dd},{ }^{3} J_{\mathrm{H}(4), \mathrm{H}(3)}=8.08 \mathrm{~Hz}\right.$, $\left.{ }^{4} J_{\mathrm{H}(4), \mathrm{H}(2)}=1.26 \mathrm{~Hz}\right), 7.89\left(\mathrm{H} 5, \mathrm{~d},{ }^{3} J_{\mathrm{H}(5), \mathrm{H}(6)}=8.76 \mathrm{~Hz}\right), 7.84(\mathrm{H} 3, \mathrm{dd}$, $\left.{ }^{3} J_{\mathrm{H}(3), \mathrm{H}(4)}=8.08 \mathrm{~Hz},{ }^{3} J_{\mathrm{H}(3), \mathrm{H}(2)}=5.26 \mathrm{~Hz}\right), 7.80\left(\mathrm{H6}, \mathrm{d},{ }^{3} J_{\mathrm{H}(6), \mathrm{H}(5)}=8.75 \mathrm{~Hz}\right)$, $7.63\left(\mathrm{H} 7, \mathrm{dd},{ }^{3} J_{\mathrm{H}(7), \mathrm{H}(8)}=7.92 \mathrm{~Hz},{ }^{4} J_{\mathrm{H}(7), \mathrm{H}(9)}=0.70 \mathrm{~Hz}\right), 7.34(\mathrm{H} 8, \mathrm{dd}$, $\left.{ }^{3} J_{\mathrm{H}(8), \mathrm{H}(9)}=8.04 \mathrm{~Hz},{ }^{3} J_{\mathrm{H}(8), \mathrm{H}(7)}=7.31 \mathrm{~Hz}\right), 6.82\left(\mathrm{H} 9, \mathrm{~d},{ }^{3} J_{\mathrm{H}(9), \mathrm{H}(8)}=6.76 \mathrm{~Hz}\right.$, $\left.{ }^{3} J_{\mathrm{H}(9), \mathrm{Pt}}=62.01 \mathrm{~Hz}\right), 3.23\left(4 \mathrm{H}-m\right.$-tht, m), 1.87 (4H-o-tht, m). ${ }^{19} \mathrm{~F}$ NMR $\left(\mathrm{Me}_{2} \mathrm{CO}-\mathrm{d}_{6}, 295 \mathrm{~K}\right), \delta-118.82\left(o-\mathrm{F},{ }^{3} J_{\mathrm{F}, \mathrm{Pt}}=512.53 \mathrm{~Hz}\right),-166.09(p-$ F), -166.90 ( $m-\mathrm{F}$, br m)

Preparation of $\quad\left[\mathbf{P t}\left(\mathrm{C}_{6} \mathbf{F}_{5}\right)(\mathbf{b z q})(\mathbf{M e C N})\right] \quad$ (5). Complex [Pt(bzq) $\left.\left(\mathrm{C}_{6} \mathrm{~F}_{5}\right)\left(\mathrm{Me}_{2} \mathrm{CO}\right)\right]$ (1) $(0.200 \mathrm{~g}, 0.335 \mathrm{mmol})$ was dissolved in MeCN $(10 \mathrm{~mL})$ at $0^{\circ} \mathrm{C}$ under $\mathrm{Ar}$ atmosphere. After 2 min of stirring the solution was evaporated to dryness. The yellow residue was treated with $n$-hexane $(10 \mathrm{~mL})$, filtered off and finally air-dried. $0.179 \mathrm{~g}, 92 \%$ yield. $\mathrm{C}_{21} \mathrm{H}_{11} \mathrm{~F}_{5} \mathrm{~N}_{2} \mathrm{Pt}$ (581.40) calcd.: C 43.38, H 1.91, N 4.82; found: C 42.99, H 1.79, N 4.71. IR ( $\left.\mathrm{cm}^{-1}\right): 2154$ (vw, $v_{\mathrm{CN}}$ ), 1497 (m), 1453 (m), 1062 (m), 953 (vs), $798\left(\mathrm{~m}, \mathrm{C}_{6} \mathrm{~F}_{5}\right.$, X-sensitive vibr. ${ }^{[103]} \cdot \Lambda_{\mathrm{M}}\left(\mathrm{Me}_{2} \mathrm{CO}\right)=7.01 \Omega^{-1} \mathrm{~cm}^{2} \mathrm{~mol}^{-1}$. ${ }^{1} \mathrm{H}$ NMR $\left(\mathrm{Me}_{2} \mathrm{CO}-\mathrm{d}_{6}, 295 \mathrm{~K}\right), \delta 9.19\left(\mathrm{H} 2, \mathrm{dd},{ }^{3} J_{\mathrm{H}(2), \mathrm{H}(3)}=5.18 \mathrm{~Hz},{ }^{4} J_{\mathrm{H}(4), \mathrm{H}(2)}\right.$ $\left.=1.20 \mathrm{~Hz},{ }^{3} J_{\mathrm{H}(2), \mathrm{Pt}}=21.78 \mathrm{~Hz}\right), 8.65\left(\mathrm{H} 4, \mathrm{dd},{ }^{3} J_{\mathrm{H}(4), \mathrm{H}(3)}=8.06 \mathrm{~Hz},{ }^{3} J_{\mathrm{H}(4), \mathrm{H}(2)}=\right.$ $1.20 \mathrm{~Hz}), 7.85\left(\mathrm{H} 5, \mathrm{~d},{ }^{3} J_{\mathrm{H}(5), \mathrm{H}(6)}=8.83 \mathrm{~Hz}\right), 7.75\left(\mathrm{H} 6, \mathrm{~d},{ }^{3} J_{\mathrm{H}(6), \mathrm{H}(5)}=8.83 \mathrm{~Hz}\right)$, $7.74\left(\mathrm{H} 3, \mathrm{~d},{ }^{3} J_{\mathrm{H}(3), \mathrm{H}(4)}=8.46 \mathrm{~Hz},{ }^{3} J_{\mathrm{H}(3) \mathrm{H}(2)}=5.00 \mathrm{~Hz}\right.$, overlapped with $\left.\mathrm{H} 6\right)$, $7.58\left(\mathrm{H} 7, \mathrm{dd},{ }^{3} J_{\mathrm{H}(7), \mathrm{H}(8)}=7.88 \mathrm{~Hz},{ }^{4} J_{\mathrm{H}(7), \mathrm{H}(9)}=0.60 \mathrm{~Hz}\right), 7.30(\mathrm{H} 8, \mathrm{dd}$, $\left.{ }^{3} J_{\mathrm{H}(7), \mathrm{H}(8)}=7.82 \mathrm{~Hz},{ }^{3} J_{\mathrm{H}(7), \mathrm{H}(9)}=7.62 \mathrm{~Hz}\right), 6.96\left(\mathrm{H} 9, \mathrm{~d},{ }^{3} J_{\mathrm{H}(9), \mathrm{H}(8)}=7.62 \mathrm{~Hz}\right.$, $\left.{ }^{3} J_{\mathrm{H}(9), \mathrm{Pt}}=58.51 \mathrm{~Hz}\right), 2.61\left(\mathrm{H}_{\mathrm{MeCN}}, \mathrm{s}\right) \cdot{ }^{19} \mathrm{~F}$ NMR $\left(\mathrm{Me}_{2} \mathrm{CO}-\mathrm{d}_{6}, 295 \mathrm{~K}\right), \delta$ $-119.08\left(o-\mathrm{F},{ }^{3} J_{\mathrm{F}, \mathrm{Pt}}=513 \mathrm{~Hz}\right),-167.12(p-\mathrm{F}), 168.05$ ( $\left.m-\mathrm{F}, \mathrm{br} \mathrm{m}\right)$.

Preparation of $\left[\left\{\mathrm{Pt}\left(\mathrm{C}_{6} \mathrm{~F}_{5}\right)(\mathrm{bzq}) \mathrm{L}\right\}_{2} \mathrm{Ag}_{\mathbf{C}} \mathrm{ClO}_{4}\left\{\mathrm{~L}=\mathrm{Me}_{2} \mathrm{CO}(6), \mathrm{PPh}_{3}\right.\right.$ (7), $\mathbf{p y P h}_{\mathbf{2}}$ (8), tht (9)\}. To a solution of [Pt(bzq) $\left.\left(\mathrm{C}_{6} \mathrm{~F}_{5}\right) \mathrm{L}\right]\left(\mathrm{L}=\mathrm{Me}_{2} \mathrm{CO}, 0.250 \mathrm{~g}\right.$, $0.418 \mathrm{mmol} ; \mathrm{L}=\mathrm{PPh}_{3}, 0.250 \mathrm{~g}, 0.187 \mathrm{mmol} ; \mathrm{L}=\mathrm{pyPh}_{2}, 0.200 \mathrm{~g}, 0.260$ mmol; $\mathrm{L}=$ tht, $0.200 \mathrm{~g}, 0.385 \mathrm{mmol})$ in $\mathrm{Me}_{2} \mathrm{CO}(20 \mathrm{~mL})$ at $0^{\circ} \mathrm{C}$ and under Ar atmosphere, $\mathrm{AgClO}_{4}\left\{\mathrm{~L}=\mathrm{Me}_{2} \mathrm{CO}, 0.043 \mathrm{~g}, 0.209 \mathrm{mmol} ; \mathrm{L}=\mathrm{PPh}_{3}\right.$, $0.019 \mathrm{~g}, 0.093 \mathrm{mmol} ; \mathrm{L}=\mathrm{pyPh}_{2}, 0.0270 \mathrm{~g}, 0.130 \mathrm{mmol}, \mathrm{L}=$ tht, $0.040 \mathrm{~g}$, $0.193 \mathrm{mmol}$ ) was added. After $30 \mathrm{~min}$ of stirring in absence of light the solution was concentrated until ca. $2 \mathrm{~mL}$. Over the resultant yellow suspension, $n$-hexane $(10 \mathrm{~mL})$ was added. The yellow precipitate was filtered off and air dried.

$\left[\left\{\mathbf{P t}\left(\mathbf{C}_{6} \mathbf{F}_{5}\right)(\mathbf{b z q})\left(\mathbf{M e}_{2} \mathbf{C O}\right)\right\}_{2} \mathbf{A g}_{\mathbf{C}} \mathbf{C l O}_{4} \quad\right.$ (6). $0.154 \quad$ g, $56 \quad \%$. $\mathrm{C}_{44} \mathrm{H}_{28} \mathrm{AgClF}_{10} \mathrm{~N}_{2} \mathrm{O}_{6} \mathrm{Pt}_{2}$ (1404.18) calcd: C 37.64, H 2.01, N 2.00; found: C 37.87, H 2.11, N 1.99. IR ( $\left.\mathrm{cm}^{-1}\right)$ : 1620 (w), 1503 (w), 1455 (w), 1442 (w), 1096 (m, v $\left.v_{\text {ClO4- }}\right), 1059$ (m), 953 (m), 801 (m, $\mathrm{C}_{6} \mathrm{~F}_{5}, \mathrm{X}$-sensitive vibr.), ${ }^{[103]}$ $621\left(\mathrm{~m}, \mathrm{v}_{\mathrm{ClO}-4}\right) . \Lambda_{\mathrm{M}}\left(\mathrm{Me}_{2} \mathrm{CO}\right)=134.35 \Omega^{-1} \mathrm{~cm}^{2} \mathrm{~mol}^{-1} .{ }^{1} \mathrm{H}$ NMR $\left(\mathrm{Me}_{2} \mathrm{CO}-\mathrm{d}_{6}\right.$, $295 \mathrm{~K}), \delta 8.70\left(\mathrm{H} 2, \mathrm{dd},{ }^{3} J_{\mathrm{H}(2), \mathrm{H}(3)}=8.11 \mathrm{~Hz},{ }^{4} J_{\mathrm{H}(2), \mathrm{H}(4)}=1.14 \mathrm{~Hz}\right), 8.64(\mathrm{H} 4$, $\left.\mathrm{m},{ }^{3} J_{\mathrm{H}(4), \mathrm{H}(3)}=8.11 \mathrm{~Hz}\right), 7.86(\mathrm{H} 3, \mathrm{H} 5$ and $\mathrm{H6}, \mathrm{m}), 7.63\left(\mathrm{H} 7, \mathrm{dd},{ }^{3} J_{\mathrm{H}(7), \mathrm{H}(8)}=\right.$ $\left.7.94 \mathrm{~Hz},{ }^{4} J_{\mathrm{H}(7), \mathrm{H}(9)}=0.52 \mathrm{~Hz}\right), 7.19\left(\mathrm{H} 8, \mathrm{dd},{ }^{3} J_{\mathrm{H}(8), \mathrm{H}(7)}=7.47 \mathrm{~Hz},{ }^{3} J_{\mathrm{H}(8), \mathrm{H}(9)}=\right.$ $7.58 \mathrm{~Hz}), 6.90\left(\mathrm{H} 9, \mathrm{~d},{ }^{3} J_{\mathrm{H}(9), \mathrm{H}(8)}=7.06 \mathrm{~Hz},{ }^{3} J_{\mathrm{H}(9), \mathrm{Pt}}=71.21 \mathrm{~Hz}\right), 2.14\left(\mathrm{H}_{\mathrm{Me} 2 \mathrm{CO}}\right.$ s). ${ }^{19} \mathrm{~F}$ NMR $\left(\mathrm{Me}_{2} \mathrm{CO}-\mathrm{d}_{6}, 295 \mathrm{~K}\right), \delta-117.89\left(o-\mathrm{F},{ }^{3} J_{\mathrm{F}, \mathrm{Pt}}=502.3 \mathrm{~Hz}\right)$, -165.06 (p-F), -166.66 ( $m-\mathrm{F}$, br m).

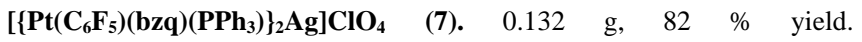
$\mathrm{C}_{74} \mathrm{H}_{46} \mathrm{AgClF}_{10} \mathrm{~N}_{2} \mathrm{O}_{4} \mathrm{P}_{2} \mathrm{Pt}_{2}$ (1812.60) calcd.: C 49.03, $\mathrm{H}$ 2.56, N 1.55; found: C 48.98, H 2.59, N 1.59. IR ( $\left.\mathrm{cm}^{-1}\right): 1500$ (m), 1458 (m), 1435 (m), 1093 (m, v clO4-), 1060 (m), 954 (s), 804 (s, $\mathrm{C}_{6} \mathrm{~F}_{5}, \mathrm{X}$-sensitive vibr.), ${ }^{[103]} 693$ (s), 621 (m, v $v_{\mathrm{ClO} 4}$ ), 529 (s, $\left.v_{\mathrm{Pph} 3}\right), 509$ (s, $\left.v_{\mathrm{Pph} 3}\right) . \Lambda_{\mathrm{M}}\left(\mathrm{Me}_{2} \mathrm{CO}\right)=266.06 \Omega^{-1} \mathrm{~cm}^{2} \mathrm{~mol}^{-1}$. ${ }^{1} \mathrm{H}$ NMR $\left(\mathrm{Me}_{2} \mathrm{CO}-\mathrm{d}_{6}, 295 \mathrm{~K}\right), \delta 8.61\left(\mathrm{H} 4, \mathrm{dd},{ }^{3} J_{\mathrm{H}(4), \mathrm{H}(3)}=8.05 \mathrm{~Hz},{ }^{4} J_{\mathrm{H}(4), \mathrm{H}(2)}\right.$ $=0.90 \mathrm{~Hz}), 8.34\left(\mathrm{H} 2, \mathrm{~d},{ }^{3} J_{\mathrm{H}(2), \mathrm{H}(3)}=5.35 \mathrm{~Hz},{ }^{3} J_{\mathrm{H}(2), \mathrm{Pt}}=25.77\right), 7.94(\mathrm{H} 5, \mathrm{~d}$, $\left.{ }^{3} J_{\mathrm{H}(5), \mathrm{H}(6)}=8.72 \mathrm{~Hz}\right), 7.82\left(\mathrm{H} 6, \mathrm{~d},{ }^{3} J_{\mathrm{H}(6), \mathrm{H}(5)}=8.74 \mathrm{~Hz}\right), 7.74(\mathrm{H} 7, \mathrm{~m}$, overlapped with $6 \mathrm{H}-m-\mathrm{Ph}, \mathrm{m}), 7.53$ (3H-p-Ph, ${ }^{3} J_{\mathrm{Hp}, \mathrm{Hm}}=7.46 \mathrm{~Hz},{ }^{4} J_{\mathrm{Hp}, \mathrm{Ho}}=$ $1.18 \mathrm{~Hz}), 7.45$ (H8 and 6H-o-Ph, m), $7.29\left(\mathrm{H} 3, \mathrm{dd},{ }^{3} J_{\mathrm{H}(3), \mathrm{H}(4)}=8.05 \mathrm{~Hz}\right.$, $\left.{ }^{3} J_{\mathrm{H}(3), \mathrm{H}(2)}=5.37 \mathrm{~Hz}\right), 7.11\left(\mathrm{H} 9, \mathrm{t},{ }^{3} J_{\mathrm{H}(9), \mathrm{H}(8)}=6.22 \mathrm{~Hz},{ }^{3} J_{\mathrm{H}(9), \mathrm{Pt}}=49.30 \mathrm{~Hz}\right) \cdot{ }^{19} \mathrm{~F}$ NMR $\left(\mathrm{Me}_{2} \mathrm{CO}-\mathrm{d}_{6}, 295 \mathrm{~K}\right), \delta-117.89\left(o-\mathrm{F},{ }^{3} J_{\mathrm{F}, \mathrm{Pt}}=504.3 \mathrm{~Hz}\right),-167.07$, -167.54 (m-F, p-F br m). ${ }^{31} \mathrm{P}$ NMR $\left(\mathrm{Me}_{2} \mathrm{CO}-\mathrm{d}_{6}, 295 \mathrm{~K}\right), \delta 27.23$ (s, $J_{\mathrm{P}, \mathrm{Pt}}=$ $2081.1 \mathrm{~Hz})$.

$\left[\left\{\mathbf{P t}\left(\mathbf{C}_{6} \mathbf{F}_{5}\right)(\mathbf{b z q})\left(\mathbf{p y P h} \mathbf{P h}_{2}\right) \boldsymbol{\}}_{2} \mathbf{A g}_{\mathbf{C}} \mathbf{C l O} \mathbf{O}_{4} \quad \mathbf{( 8 )} . \quad 0.207 \quad\right.\right.$ g, $\quad 96 \quad \% \quad$ yield. $\mathrm{C}_{72} \mathrm{H}_{42} \mathrm{AgClF}_{10} \mathrm{~N}_{4} \mathrm{O}_{4} \mathrm{Pt}_{2}(1750.61)$ calcd.: C 49.40, H 2.42, N 3.20; found: C 48.97, H 2.52, N 3.34. IR ( $\left.\mathrm{cm}^{-1}\right)$ : 1501 (w), 1452 (w), 1439 (w), 1093 (w, 
$v_{\mathrm{ClO} 4}$ ), 1058 (m), 953 (m), 797 (s, $\mathrm{C}_{6} \mathrm{~F}_{5}, \mathrm{X}$-sensitive vibr.), ${ }^{[103]} 622$ (w, v $\mathrm{v}_{\mathrm{ClO} 4-}$ ), $696(\mathrm{w}) \cdot \Lambda_{\mathrm{M}}\left(\mathrm{Me}_{2} \mathrm{CO}\right)=241.43 \Omega^{-1} \mathrm{~cm}^{2} \mathrm{~mol}^{-1} .{ }^{1} \mathrm{H}$ NMR $\left(\mathrm{Me}_{2} \mathrm{CO}-\mathrm{d}_{6}, 295\right.$ $\mathrm{K}), \delta 8.70\left(\mathrm{H} 2, \mathrm{dd},{ }^{3} J_{\mathrm{H}(2), \mathrm{H}(3)}=8.12 \mathrm{~Hz},{ }^{4} J_{\mathrm{H}(2), \mathrm{H}(4)}=1.10 \mathrm{~Hz}\right.$, overlapped with H4), 8.67 (H4, m, overlapped with H2), 8.02 (H-p-py, m), 8.15 (4H-o-Ph, m), $7.90(2 \mathrm{H}-m-\mathrm{py}, \mathrm{m}), 7.88\left(\mathrm{H} 5, \mathrm{~d},{ }^{3} \mathrm{~J}_{\mathrm{H}(5), \mathrm{H}(6)}=8.79 \mathrm{~Hz}\right), 7.84(\mathrm{H} 6, \mathrm{~d}$, $\left.{ }^{3} J_{\mathrm{H}(6), \mathrm{H}(5)}=8.85 \mathrm{~Hz}\right), 7.63\left(\mathrm{H} 7, \mathrm{dd},{ }^{3} J_{\mathrm{H}(7), \mathrm{H}(8)}=7.97 \mathrm{~Hz},{ }^{4} J_{\mathrm{H}(7), \mathrm{H}(9)}=0.54 \mathrm{~Hz}\right)$, $7.49(4 \mathrm{H}-m-\mathrm{Ph}$ and $2 \mathrm{H}-p-\mathrm{Ph}, \mathrm{m}), 7.24\left(\mathrm{H} 8, \mathrm{dd},{ }^{3} \mathrm{~J}_{\mathrm{H}(8), \mathrm{H}(7)}=7.62 \mathrm{~Hz},{ }^{3} J_{\mathrm{H}(8), \mathrm{H}(9)}\right.$ $=7.45 \mathrm{~Hz}), 6.89\left(\mathrm{H} 9, \mathrm{~d},{ }^{3} \mathrm{~J}_{\mathrm{H}(9), \mathrm{H}(8)}=7.28 \mathrm{~Hz},{ }^{3} J_{\mathrm{H}(9), \mathrm{Pt}}=71.51 \mathrm{~Hz}\right) .{ }^{19} \mathrm{~F} \mathrm{NMR}$ $\left(\mathrm{Me}_{2} \mathrm{CO}-\mathrm{d}_{6}, 295 \mathrm{~K}\right), \delta-118.26\left(o-\mathrm{F},{ }^{3} J_{\mathrm{F}, \mathrm{Pt}}=505.91 \mathrm{~Hz}\right),-165.50(p-$ F), -166.94 ( $m-\mathrm{F}$, br m).

$\left[\left\{\mathbf{P t}\left(\mathbf{C}_{6} \mathbf{F}_{5}\right)(\mathbf{b z q})(\mathbf{t h t})\right\}_{2} \mathbf{A g}_{\mathbf{C}} \mathbf{C l O}_{4} \quad \mathbf{( 9 )} . \quad 0.200 \quad\right.$ g, $\quad 71 \% \quad$ yield. $\mathrm{C}_{46} \mathrm{H}_{32} \mathrm{AgClF}_{10} \mathrm{~N}_{2} \mathrm{O}_{4} \mathrm{Pt}_{2} \mathrm{~S}_{2}$ (1464.37) calcd.: C 37.73, H 2.20, N 1.91, S 4.38; found: C 37.29, H 2.01, N 1.92, S 3.89. IR $\left(\mathrm{cm}^{-1}\right)$ : 1503 (m), 1453 (m),

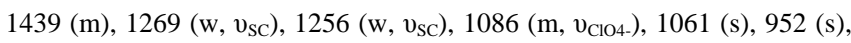
801 (m, $\mathrm{C}_{6} \mathrm{~F}_{5}$, X-sensitive vibr.), ${ }^{[103]} 621$ (w, v $\mathrm{v}_{\mathrm{ClO} 4}$-). $\Lambda_{\mathrm{M}}\left(\mathrm{Me}_{2} \mathrm{CO}\right)=238.73$ $\Omega^{-1} \mathrm{~cm}^{2} \mathrm{~mol}^{-1} .{ }^{1} \mathrm{H}$ NMR (Acetone- $\left.\mathrm{d}_{6}, 295 \mathrm{~K}\right), \delta 9.26\left(\mathrm{H} 2\right.$, dd, ${ }^{3} J_{\mathrm{H}(2), \mathrm{H}(3)}=5.24$ $\left.\mathrm{Hz},{ }^{4} J_{\mathrm{H}(2), \mathrm{H}(4)}=1.27 \mathrm{~Hz},{ }^{3} J_{\mathrm{H}(2), \mathrm{Pt}}=21.9 \mathrm{~Hz}\right), 8.77\left(\mathrm{H} 4, \mathrm{dd},{ }^{3} J_{\mathrm{H}(4), \mathrm{H}(3)}=8.10 \mathrm{~Hz}\right.$ $\left.{ }^{4} J_{\mathrm{H}(4), \mathrm{H}(2)}=1.21 \mathrm{~Hz}\right), 7.93\left(\mathrm{H} 3, \mathrm{dd},{ }^{3} J_{\mathrm{H}(3), \mathrm{H}(4)}=8.08 \mathrm{~Hz},{ }^{3} J_{\mathrm{H}(3), \mathrm{H}(2)}=5.23 \mathrm{~Hz}\right)$, $7.91\left(\mathrm{H} 5, \mathrm{~d},{ }^{3} J_{\mathrm{H}(5), \mathrm{H}(6)}=8.74 \mathrm{~Hz}\right), 7.86\left(\mathrm{H} 6, \mathrm{~d},{ }^{3} J_{\mathrm{H}(6) \mathrm{H}(5)}=8.77 \mathrm{~Hz}\right), 7.73(\mathrm{H} 7$, $\left.\mathrm{dd},{ }^{3} J_{\mathrm{H}(7), \mathrm{H}(8)}=8.00 \mathrm{~Hz},{ }^{4} J_{\mathrm{H}(7), \mathrm{H}(9)}=0.70 \mathrm{~Hz}\right), 7.34\left(\mathrm{H} 8, \mathrm{dd},{ }^{3} J_{\mathrm{H}(8), \mathrm{H}(9)}=7.89\right.$ $\left.\mathrm{Hz},{ }^{3} J_{\mathrm{H}(8), \mathrm{H}(7)}=7.20 \mathrm{~Hz}\right), 6.86\left(\mathrm{H} 9, \mathrm{~d},{ }^{3} J_{\mathrm{H}(9), \mathrm{H}(8)}=7.03 \mathrm{~Hz},{ }^{3} J_{\mathrm{H}(9), \mathrm{Pt}}=58.53\right.$ $\mathrm{Hz}$ ), 3.17 (4H-m-tht, m), 1.86 (4H-o-tht, m). ${ }^{19} \mathrm{~F}$ NMR $\left(\mathrm{Me}_{2} \mathrm{CO}-\mathrm{d}_{6}, 295 \mathrm{~K}\right)$, $\delta-117.47\left(o-\mathrm{F},{ }^{3} J_{\mathrm{F}, \mathrm{Pt}}=506.05 \mathrm{~Hz}\right),-164.62(p-\mathrm{F}),-165.86(\mathrm{~m}-\mathrm{F}, \mathrm{br} \mathrm{m})$.

Preparation of $\left[\left\{\mathbf{P t}\left(\mathrm{C}_{6} \mathrm{~F}_{5}\right)(\mathbf{b z q})(\mathrm{MeCN})\right\}_{2} \mathrm{Ag}_{\mathbf{C}} \mathbf{C l O}_{4}(\mathbf{1 0})\right.$. To a solution of [Pt(bzq) $\left.\left(\mathrm{C}_{6} \mathrm{~F}_{5}\right)(\mathrm{MeCN})\right](0.200 \mathrm{~g}, 0.344 \mathrm{mmol})$ in $\mathrm{Me}_{2} \mathrm{CO}(20 \mathrm{~mL})$ at $0^{\circ} \mathrm{C}$ and under $\mathrm{Ar}$ atmosphere, $\mathrm{AgClO}_{4}\{0.0357 \mathrm{~g}, 0.172 \mathrm{mmol}$ ) was added. After 30 min of stirring in absence of light the solution was evaporated to dryness. The yellow residue was treated with $n$-hexane $(10 \mathrm{~mL})$, filtered off and finally air-dried. $0.211 \mathrm{~g}, 96 \%$ yield. $\mathrm{C}_{42} \mathrm{H}_{22} \mathrm{AgClF}_{10} \mathrm{~N}_{4} \mathrm{O}_{4} \mathrm{Pt}_{2}(1370.13)$ calcd.: C 36.82, H 1.62, N 4.09; found: C 37.17, H 2.02, N 3.73. IR ( $\left(\mathrm{cm}^{-1}\right)$ :

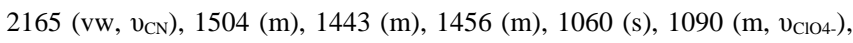
953 (s), 804 (m, $\mathrm{C}_{6} \mathrm{~F}_{5}$, X-sensitive vibr.) ${ }^{[103]} 623$ (m, v $v_{\mathrm{ClO} 4}$ ). $\Lambda_{\mathrm{M}}\left(\mathrm{Me}_{2} \mathrm{CO}\right)=$ $225.67 \Omega^{-1} \mathrm{~cm}^{2} \mathrm{~mol}^{-1} .{ }^{1} \mathrm{H}$ NMR $\left(\mathrm{Me}_{2} \mathrm{CO}-\mathrm{d}_{6}, 295 \mathrm{~K}\right), \delta 9.17\left(\mathrm{H} 2, \mathrm{dd},{ }^{3} J_{\mathrm{H}(2), \mathrm{H}(3)}\right.$ $\left.=5.13 \mathrm{~Hz},{ }^{3} J_{\mathrm{H}(2), \mathrm{H}(4)}=1.06 \mathrm{~Hz},{ }^{3} J_{\mathrm{H}(2), \mathrm{Pt}}=24.70 \mathrm{~Hz}\right), 8.73\left(\mathrm{H} 4, \mathrm{dd},{ }^{3} J_{\mathrm{H}(4), \mathrm{H}(3)}=\right.$ $\left.8.18 \mathrm{~Hz},{ }^{4} J_{\mathrm{H}(4), \mathrm{H}(2)}=1.03 \mathrm{~Hz}\right), 7.89\left(\mathrm{H} 5, \mathrm{~d},{ }^{3} J_{\mathrm{H}(5), \mathrm{H}(6)}=8.74 \mathrm{~Hz}\right), 7.87(\mathrm{H} 3, \mathrm{~m}$, overlapped with $\mathrm{H} 5$ and $\mathrm{H6}$ ), $7.84\left(\mathrm{H} 6, \mathrm{~d},{ }^{3} J_{\mathrm{H}(6), \mathrm{H}(5)}=8.79 \mathrm{~Hz}\right), 7.68(\mathrm{H7}, \mathrm{d}$, $\left.{ }^{3} J_{\mathrm{H}(7), \mathrm{H}(8)}=7.95 \mathrm{~Hz}\right), 7.27\left(\mathrm{H} 8, \mathrm{dd},{ }^{3} J_{\mathrm{H}(8), \mathrm{H}(7)}=7.75 \mathrm{~Hz},{ }^{3} J_{\mathrm{H}(8), \mathrm{H}(9)}=7.69 \mathrm{~Hz}\right)$, $6.95\left(\mathrm{H} 9, \mathrm{~d},{ }^{3} J_{\mathrm{H}(9), \mathrm{H}(8)}=7.69 \mathrm{~Hz},{ }^{3} J_{\mathrm{H}(9), \mathrm{Pt}}=63.0 \mathrm{~Hz}\right), 2.65\left(\mathrm{H}_{\mathrm{MeCN}}, \mathrm{s}\right) .{ }^{19} \mathrm{~F}$ NMR ( $\left.\mathrm{Me}_{2} \mathrm{CO}-\mathrm{d}_{6}, 295 \mathrm{~K}\right), \delta-117.87\left(o-\mathrm{F},{ }^{3} J_{\mathrm{F}, \mathrm{Pt}}=492.0 \mathrm{~Hz}\right),-165.81(p-$ F), -167.14 ( $m-\mathrm{F}$, br m).

Preparation of $\left[\mathrm{Pt}\left(\mathrm{C}_{6} \mathrm{~F}_{5}\right)(\mathbf{b z q})\left(\mathbf{P P h}_{3}\right) \mathbf{A g}\left(\mathrm{pyPh}_{2}\right)\right] \mathrm{ClO}_{4}$ (11). To a solution of $\left[\mathrm{Pt}(\mathrm{bzq})\left(\mathrm{C}_{6} \mathrm{~F}_{5}\right)\left(\mathrm{pyPh}_{2}\right)\right](0.200 \mathrm{~g}, 0.259 \mathrm{mmol})$ in $\mathrm{Me}_{2} \mathrm{CO}(20 \mathrm{~mL})$ at $0^{\circ} \mathrm{C}$ and under $\mathrm{Ar}$ atmosphere, $\left[\mathrm{Ag}\left(\mathrm{OClO}_{3}\right)\left(\mathrm{PPh}_{3}\right)\right](0.121 \mathrm{~g}, 0.259 \mathrm{mmol})$ was added. After $30 \mathrm{~min}$ of stirring in absence of light the solution was evaporated to dryness. The oily yellow residue was treated with $n$-hexane $(10 \mathrm{~mL})$ and allowed to stir for $60 \mathrm{~min}$. After this time, the yellow solid formed is filtered off and finally air-dried. $0.263 \mathrm{~g}, 88 \%$ yield. $\mathrm{C}_{54} \mathrm{H}_{36} \mathrm{AgClF}_{5} \mathrm{~N}_{2} \mathrm{O}_{4} \mathrm{PPt}(1241.25)$ calcd.: C 52.25, H 2.92, N 2.26; found: C 52.02, H 2.81, N 2.24. IR ( $\left.\mathrm{cm}^{-1}\right): 1501$ (w), 1456 (w), 1435 (w), 1092 (m,

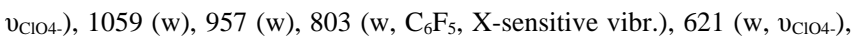
$693(\mathrm{w}), 531(\mathrm{w}), 512(\mathrm{w}) . \Lambda_{\mathrm{M}}\left(\mathrm{Me}_{2} \mathrm{CO}\right)=246.87 \Omega^{-1} \mathrm{~cm}^{2} \mathrm{~mol}^{-1} .{ }^{1} \mathrm{H}$ NMR $\left(\mathrm{Me}_{2} \mathrm{CO}-\mathrm{d}_{6}, 295 \mathrm{~K}\right), \delta 8.64\left(\mathrm{H} 4, \mathrm{dd},{ }^{3} J_{\mathrm{H}(4), \mathrm{H}(3)}=8.07 \mathrm{~Hz},{ }^{3} J_{\mathrm{H}(4), \mathrm{H}(2)}=1.0 \mathrm{~Hz}\right)$, $8.34\left(\mathrm{H} 2, \mathrm{~d},{ }^{3} J_{\mathrm{H}(2), \mathrm{H}(3)}=5.36 \mathrm{~Hz},{ }^{3} J_{\mathrm{H}(2), \mathrm{Pt}}=26.36 \mathrm{~Hz}\right), 8.15(4 \mathrm{H}-\mathrm{o}-\mathrm{Ph}, \mathrm{m})$, 8.06 (H-p-py, m), 7.99 (H5, d, $\left.{ }^{3} J_{\mathrm{H}(5), \mathrm{H}(6)}=8.74 \mathrm{~Hz}\right), 7.91$ (2H-m-py, m), $7.85\left(\mathrm{H} 6, \mathrm{~d},{ }^{3} J_{\mathrm{H}(6), \mathrm{H}(5)}=8.87 \mathrm{~Hz}\right), 7.74$ (H7 and H-m-Ph $\left.\left(\mathrm{PPh}_{3}\right), \mathrm{m}\right), 7.55-$ 7.42 (H8 and 3H-p-Ph $\left(\mathrm{PPh}_{3}\right), 6 \mathrm{H}-\mathrm{o}-\mathrm{Ph}\left(\mathrm{PPh}_{3}\right), 4 \mathrm{H}-m-\mathrm{Ph}\left(\mathrm{PPh}_{2}\right), 2 \mathrm{H}-\mathrm{p}-\mathrm{Ph}$ $\left.\left(\mathrm{PPh}_{2}\right), \mathrm{m}\right), 7.32\left(\mathrm{H} 6, \mathrm{dd},{ }^{3} J_{\mathrm{H}(3), \mathrm{H}(4)}=8.06 \mathrm{~Hz},{ }^{4} J_{\mathrm{H}(3), \mathrm{H}(2)}=5.38 \mathrm{~Hz}\right), 7.13(\mathrm{H} 9$, $\left.\mathrm{t},{ }^{3} J_{\mathrm{H}(9), \mathrm{H}(8)}=6.21 \mathrm{~Hz},{ }^{3} J_{\mathrm{H}(2), \mathrm{Pt}}=47.40\right) .{ }^{19} \mathrm{~F}$ NMR $\left(\mathrm{Me}_{2} \mathrm{CO}-\mathrm{d}_{6}, 295 \mathrm{~K}\right), \delta$ $-116.93\left(o-\mathrm{F},{ }^{3} J_{\mathrm{F}, \mathrm{Pt}}=500.65 \mathrm{~Hz}\right), 167.16(m-\mathrm{F}, \mathrm{br} \mathrm{m}),-166.88(p-\mathrm{F}) .{ }^{31} \mathrm{P}$ NMR $\left(\mathrm{Me}_{2} \mathrm{CO}-\mathrm{d}_{6}, 295 \mathrm{~K}\right), \delta 26.59\left(\mathrm{~s}, J_{\mathrm{P}, \mathrm{Pt}}=2147.8 \mathrm{~Hz}\right)$.
Table 12. Crystal data and structure refinement for complexes $\left[\mathrm{Pt}\left(\mathrm{C}_{6} \mathrm{~F}_{5}\right)(\mathrm{bzq})\left(\mathrm{PPh}_{3}\right)\right] \cdot 0.2 \mathrm{Me}_{2} \mathrm{CO} \quad\left(2 \cdot 0.2 \mathrm{Me}_{2} \mathrm{CO}\right), \quad\left[\mathrm{Pt}\left(\mathrm{C}_{6} \mathrm{~F}_{5}\right)(\mathrm{bzq})(\right.$ tht $\left.)\right]$ $\cdot 2 / 3 \mathrm{CH}_{2} \mathrm{Cl}_{2}\left(\mathbf{4} \cdot 2 / 3 \mathrm{CH}_{2} \mathrm{Cl}_{2}\right)$ and $\left[\mathrm{Pt}\left(\mathrm{C}_{6} \mathrm{~F}_{5}\right)(\mathrm{bzq})(\mathrm{MeCN})\right](5)$.

\begin{tabular}{|c|c|c|c|}
\hline & $2 \cdot 0.2 \mathrm{Me}_{2} \mathrm{CO}$ & $4 \cdot 2 / 3 \mathrm{CH}_{2} \mathrm{Cl}_{2}$ & 5 \\
\hline Formula & $\begin{array}{l}\mathrm{C}_{37} \mathrm{H}_{23} \mathrm{~F}_{5} \mathrm{NPPt} \\
\cdot 0.2 \mathrm{Me}_{2} \mathrm{CO}\end{array}$ & $\begin{array}{l}\mathrm{C}_{23} \mathrm{H}_{16} \mathrm{~F}_{5} \mathrm{NPtS} \\
\cdot 2 / 3 \mathrm{CH}_{2} \mathrm{Cl}_{2}\end{array}$ & $\mathrm{C}_{21} \mathrm{H}_{11} \mathrm{~F}_{5} \mathrm{~N}_{2} \mathrm{Pt}$ \\
\hline Formula weight & 814.24 & 685.14 & 581.41 \\
\hline Crystal system & Triclinic & Monoclinic & Monoclinic \\
\hline Space group & $P-1$ & $P_{C}$ & $P 2_{1} / c$ \\
\hline$a[\AA]$ & $14.3213(3)$ & 16.1169(3) & 13.851(2) \\
\hline$b[\AA]$ & $14.7249(4)$ & $12.4389(2)$ & $7.4016(7)$ \\
\hline$c[\AA]$ & $16.0887(5)$ & $16.4671(3)$ & $17.653(2)$ \\
\hline$\alpha\left[^{\circ}\right]$ & $80.101(3)$ & 90 & 90 \\
\hline$\beta\left[^{\circ}\right]$ & 79.902(2) & $93.036(2)$ & $108.066(14)$ \\
\hline$\gamma\left[^{0}\right]$ & $66.437(2)$ & 90 & 90 \\
\hline$V\left[\AA^{3}\right]$ & $3042.17(14)$ & 3296.63(10) & 12406.2(7) \\
\hline$Z$ & 4 & 6 & 4 \\
\hline$D_{c}\left[\mathrm{~g} \mathrm{~cm}^{-3}\right]$ & 1.778 & 2.071 & 2.245 \\
\hline$T[\mathrm{~K}]$ & $100(1)$ & $100(1)$ & $100(1)$ \\
\hline$\mu\left(\mathrm{Mo}-K_{\alpha}\right)\left[\mathrm{mm}^{-1}\right]$ & 4.726 & 6.697 & 8.217 \\
\hline$F(000)$ & 1586 & 1968 & 1096 \\
\hline$\theta$ range $\left[^{\circ}\right]$ & $4.2-26.0$ & $4.2-28.9$ & $4.1-25.5$ \\
\hline $\begin{array}{c}\text { Reflections } \\
\text { collected }\end{array}$ & 28562 & 34078 & 11311 \\
\hline $\begin{array}{l}\text { Independent } \\
\text { reflections }\end{array}$ & 11905 & 14799 & 3170 \\
\hline$R_{\text {int }}$ & 0.0292 & 0.0425 & 0.0601 \\
\hline$R_{1}, w R_{2}^{a}(I>2 \sigma(I))$ & $0.0426,0.0826$ & $0.0364,0.0908$ & $0.0416,0.0988$ \\
\hline$R_{1}, w R_{2}^{a}$ (all data) & $0.0536,0.0849$ & $0.0413,0.0926$ & $0.0525,0.1026$ \\
\hline $\operatorname{GOF}\left(F^{2}\right)^{b}$ & 1.122 & 1.030 & 1.030 \\
\hline $\begin{array}{l}\text { Absolute } \\
\text { structure par. }\end{array}$ & - & $0.020(5)$ & - \\
\hline
\end{tabular}

${ }^{a} R_{1}=\sum\left(\left|F_{\mathrm{O}}\right|-\left|F_{\mathrm{C}}\right|\right) / \sum\left|F_{\mathrm{O}}\right| \cdot w R_{2}=\left[\sum \mathrm{w}\left(F_{\mathrm{O}}{ }^{2}-F_{\mathrm{C}}{ }^{2}\right)^{2} / \sum \mathrm{w}\left(F_{\mathrm{O}}{ }^{2}\right)^{2}\right]^{1 / 2} \cdot{ }^{b}$ Goodness-of-fit $=\left[\sum \mathrm{w}\left(F_{\mathrm{O}}^{2}-F_{\mathrm{C}}{ }^{2}\right)^{2} /\left(n_{\mathrm{obs}}-n_{\text {param }}\right)\right]^{1 / 2}$.

X-ray structure determinations. Crystal data and other details of the structure analyses are presented in Tables 12 and 13. Suitable crystals for $\mathrm{X}$-ray diffraction studies were obtained by slow diffusion of $n$-hexane into concentrated solutions of the complexes in $3 \mathrm{~mL}$ of $\mathrm{CH}_{2} \mathrm{Cl}_{2}$ or $\mathrm{Me}_{2} \mathrm{CO}$. Crystals were mounted at the end of quartz fibres. The radiation used in all cases was graphite monochromated $\operatorname{MoK} \alpha(\lambda=0.71073 \AA)$. X-ray intensity data were collected on an Oxford Diffraction Xcalibur diffractometer. The diffraction frames were integrated and corrected from absorption by using the CrysAlis RED program. ${ }^{[104]}$ The structures were solved by Patterson and Fourier methods and refined by full-matrix least squares on $F^{2}$ with SHELXL-97. ${ }^{[105]}$ All non-hydrogen atoms were assigned anisotropic displacement parameters and refined without positional constraints, except as noted below. All hydrogen atoms were constrained to idealized geometries and assigned isotropic displacement parameters equal

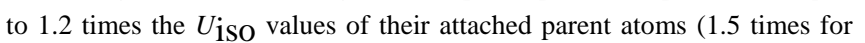
the methyl hydrogen atoms). In the structure of $4 \cdot 2 / 3 \mathrm{CH}_{2} \mathrm{Cl}_{2}$, three complete complexes are found in the asymmetric unit. In two of them, the $\beta$ $\mathrm{CH}_{2}$ fragments of the tht ligands are disordered over two positions which were refined with partial occupancy $0.60 / 0.40$ and $0.65 / 0.35$. Weak restraints were applied in the interatomic $\mathrm{C}-\mathrm{C}$ distances and thermal parameters of these fragments. For $\mathbf{1 0} \cdot 2.5 \mathrm{CH}_{2} \mathrm{Cl}_{2} \cdot 0.5 n-\mathrm{C}_{6} \mathrm{H}_{14}$, restraints were used in some structural and thermal parameters of the $\mathrm{C}$ atoms of the bzq ligands. Very diffuse solvent was found during the refinement stages and was modelled as several dichloromethane moieties, some of them disordered, with a total occupancy of 2.5 , and half of a $n$-hexane molecule. Restrains were used in the structural and thermal parameters of these units. 
Table 13. Crystal data and structure refinement for complexes $\left[\left\{\mathrm{Pt}_{(}\left(\mathrm{C}_{6} \mathrm{~F}_{5}\right)(\mathrm{bzq})\left(\mathrm{PPh}_{3}\right)\right\}_{2} \mathrm{Ag} \mathrm{ClO}_{4} \cdot \mathrm{CH}_{2} \mathrm{Cl}_{2} \quad\left(7 \cdot \mathrm{CH}_{2} \mathrm{Cl}_{2}\right)\right.$, $\left[\left\{\mathrm{Pt}_{(}\left(\mathrm{C}_{6} \mathrm{~F}_{5}\right)(\mathrm{bzq})(\mathrm{tht})\right\}_{2} \mathrm{Ag}\right] \mathrm{ClO}_{4} \cdot 1.5 \mathrm{Me}_{2} \mathrm{CO} \quad\left(\mathbf{9} \cdot 1.5 \mathrm{Me}_{2} \mathrm{CO}\right), \quad\left[\left\{\mathrm{Pt}_{(}\left(\mathrm{C}_{6} \mathrm{~F}_{5}\right)(\mathrm{bzq})(\mathrm{MeCN})\right\}_{2} \mathrm{Ag}\right] \mathrm{ClO}_{4} \cdot 2.5 \mathrm{CH}_{2} \mathrm{Cl}_{2} \cdot 0.5 n-\mathrm{C}_{6} \mathrm{H}_{14} \quad\left(\mathbf{1 0} \cdot 2.5 \mathrm{CH}_{2} \mathrm{Cl}_{2} \cdot 0.5 n-\mathrm{C}_{6} \mathrm{H}_{14}\right), \quad$ and $\left[\left(\mathrm{C}_{6} \mathrm{~F}_{5}\right)(\mathrm{bzq})\left(\mathrm{PPh}_{3}\right) \mathrm{Pt}\left(\mathrm{pyPh}_{2}\right)\right] \mathrm{ClO}_{4} \cdot \mathrm{CH}_{2} \mathrm{Cl}_{2}\left(\mathbf{1 1} \cdot \mathrm{CH}_{2} \mathrm{Cl}_{2}\right)$.

\begin{tabular}{|c|c|c|c|c|}
\hline & $7 \cdot \mathrm{CH}_{2} \mathrm{Cl}_{2}$ & $\mathbf{9} \cdot 1.5 \mathrm{Me}_{2} \mathrm{CO}$ & $\mathbf{1 0} \cdot 2.5 \mathrm{CH}_{2} \mathrm{Cl}_{2} \cdot 0.5 n-\mathrm{C}_{6} \mathrm{H}_{14}$ & 11. $\mathrm{CH}_{2} \mathrm{Cl}_{2}$ \\
\hline \multirow[t]{2}{*}{ Formula } & $\mathrm{C}_{74} \mathrm{H}_{46} \mathrm{AgClF}_{10} \mathrm{~N}_{2} \mathrm{O}_{4} \mathrm{P}_{2} \mathrm{Pt}_{2}$ & $\mathrm{C}_{46} \mathrm{H}_{32} \mathrm{AgClF}_{10} \mathrm{~N}_{2} \mathrm{O}_{4} \mathrm{Pt}_{2} \mathrm{~S}_{2}$ & $\mathrm{C}_{42} \mathrm{H}_{22} \mathrm{AgClF}_{10} \mathrm{~N}_{4} \mathrm{O}_{4} \mathrm{Pt}_{2}$ & $\mathrm{C}_{54} \mathrm{H}_{36} \mathrm{AgClF}_{5} \mathrm{~N}_{2} \mathrm{O}_{4} \mathrm{PPt}$ \\
\hline & $\cdot \mathrm{CH}_{2} \mathrm{Cl}_{2}$ & $\cdot 1.5 \mathrm{Me}_{2} \mathrm{CO}$ & $2.5 \mathrm{CH}_{2} \mathrm{Cl}_{2} \cdot 0.5 n-\mathrm{C}_{6} \mathrm{H}_{14}$ & $\cdot \mathrm{CH}_{2} \mathrm{Cl}_{2}$ \\
\hline$M_{t}$ & 1897.49 & 1551.47 & 1625.54 & 1326.15 \\
\hline Crystal system & Monoclinic & Triclinic & Triclinic & Triclinic \\
\hline Space group & $P 2_{1} / c$ & $P-1$ & $P-1$ & $P-1$ \\
\hline$a[\AA]$ & $13.1438(2)$ & 13.5673(8) & $13.9756(4)$ & $13.4888(2)$ \\
\hline$b[\AA]$ & 35.7903(8) & $14.4385(11)$ & 14.3662(3) & $13.5126(2)$ \\
\hline$c[\AA]$ & 14.3105(3) & 15.3982(8) & 16.1823(3) & $14.6245(2)$ \\
\hline$\alpha\left[^{\circ}\right]$ & 90 & 72.599(6) & 79.6218(17) & 106.249(1) \\
\hline$\beta\left[^{\circ}\right]$ & $102.9667(19)$ & $68.987(5)$ & $69.783(2)$ & 107.091(1) \\
\hline$\gamma\left[^{\circ}\right]$ & 90 & $64.745(7)$ & $64.539(2)$ & $90.684(1)$ \\
\hline$V\left[\AA^{3}\right]$ & $6560.3(2)$ & 2508.2(3) & $2750.84(11)$ & 2433.18(6) \\
\hline$Z$ & 4 & 2 & 2 & 2 \\
\hline$D_{c}\left[\mathrm{~g} \mathrm{~cm}^{-3}\right]$ & 1.921 & 2.052 & 1.963 & 1.810 \\
\hline$T[\mathrm{~K}]$ & $100(1)$ & $100(1)$ & $100(1)$ & $100(1)$ \\
\hline$\mu\left[\mathrm{mm}^{-1}\right]$ & 4.804 & 6.175 & 5.796 & 3.542 \\
\hline$F(000)$ & 3672 & 1485 & 1548 & 1300 \\
\hline$\theta$ range $\left[^{\circ}\right]$ & $4.2-28.9$ & 4.3-28.9 & 4.1-28.9 & $4.2-35.3$ \\
\hline Reflections collected & 57416 & 49929 & 58605 & 91933 \\
\hline Independent reflections & 15626 & 11819 & 13069 & 18524 \\
\hline$R_{\text {int }}$ & 0.0427 & 0.0600 & 0.0624 & 0.0286 \\
\hline$R_{1}, w R_{2}^{a}(I>2 \sigma(I))$ & $0.0347,0.0566$ & $0.0395,0.0997$ & $0.0571,0.1524$ & $0.0190,0.0419$ \\
\hline$R_{1}, w R_{2}^{a}$ (all data) & $0.0531,0.0586$ & $0.0569,0.1070$ & $0.0942,0.1646$ & $0.0244,0.0425$ \\
\hline $\operatorname{GOF}\left(F^{2}\right)^{b}$ & 1.008 & 1.044 & 1.030 & 1.027 \\
\hline
\end{tabular}

${ }^{a} R_{1}=\sum\left(\left|F_{\mathrm{O}}\right|-\left|F_{\mathrm{C}}\right|\right) / \sum\left|F_{\mathrm{O}}\right| \cdot w R_{2}=\left[\sum \mathrm{w}\left(F_{\mathrm{O}}{ }^{2}-F_{\mathrm{C}}{ }^{2}\right)^{2} / \sum \mathrm{w}\left(F_{\mathrm{O}}{ }^{2}\right)^{2}\right]^{1 / 2} \cdot{ }^{b}$ Goodness-of-fit $=\left[\sum \mathrm{w}\left(F_{\mathrm{O}}{ }^{2}-F_{\mathrm{C}}{ }^{2}\right)^{2} /\left(n_{\mathrm{obs}}-n_{\mathrm{param}}\right)\right]^{1 / 2}$.

Full-matrix least-squares refinement of these models against $F^{2}$ converged to final residual indices given in Tables 12 and 13. CCDC 906692-906698 contain the supplementary crystallographic data for this paper. These data can be obtained free of charge from the Cambridge Crystallographic Data Centre via www.ccdc.cam.ac.uk/data_request/cif.

Computational Methods. Density functional calculations were performed using the hybrid functionals B3LYP ${ }^{[106,107]}$ for complexes $\mathbf{2 ,} \mathbf{4}$ and $\mathbf{5}$ and the M06 ${ }^{[108]}$ for complexes 9-11Me under the Gaussian09 package. ${ }^{[109]}$ The SDD pseudopotential and associated basis set ${ }^{[110]}$ was used for platinum and silver atoms, and the 6-31G(d $)^{[111,112]}$ basis set was used for all other atoms. Geometry optimisations were performed under no symmetry restrictions, using initial coordinates derived from X-ray data of the same or comparable complexes. Frequency calculations were used to confirm the stationary points were true minima. The time-dependent density-functional (TD-DFT) calculations were performed using the polarized continuum model approach implemented in the Gaussian 09 software. A Mulliken population analysis was included for interpretation purposes. Molecular orbitals were visualized using the Molekel program package. ${ }^{[113]}$

Supporting Information (see footnote on the first page of this article): Absorption data of $10^{-4} \mathrm{M}$ solutions of 1-11 at room temperature (Table S1). DFT-Optimized coordinates and selected singlet excited states calculated by TD-DFT for complexes $2,4,5,9,10$ and $11 \mathrm{Me}$ in $\mathrm{CH}_{2} \mathrm{Cl}_{2}$ (Tables S2S7). Emission data of $10^{-3} \mathrm{M}$ solutions of 1-5 at 77K (Table S8). Views of the supramolecular arrangement showing the $\pi \cdots \pi$ stacking for complexes 2 and 5 (Figures S1 and S2). Normalized absorption spectra of $\mathbf{2}$ in solution of different solvents $\left(10^{-4} \mathrm{M}\right)$ at room temperature (Figure S3). Energy levels and electron-density diagrams of the frontier molecular orbitals involved in the lower energy excited calculated states for 4, 5, 9 and 10 (Figures S4 and S5). Normalized DRUV spectra of complexes 1-5 in the solid state (Figure S6). Normalized emission and excitation spectra of $\mathbf{5}$ and $\mathbf{1 0}$ in the solid state (Figure S7).

\section{Acknowledgments}

This work was supported by the Spanish MICINN (DGPTC/FEDER) (Project CTQ2008-06669-C02-01/BQU). We thank Mariano Perálvarez (IREC) for the QY measurements.

[1] P. Pyykkö, Chem. Rev. 1997, 97, 597.

[2] P. Pyykkö, Angew. Chem. Int. Ed. 2004, 43, 4412.

[3] L. H. Gade, Angew. Chem. Int. Ed. 2001, 40, 3573.

[4] M. A. Carvajal, S. Álvarez, J. J. Novoa, Chem, Eur. J. 2004, 10, 2117.

[5] A. Díez, E. Lalinde, M. T. Moreno, Coord. Chem. Rev. 2011, 255, 2426.

[6] E. J. Fernández, A. Laguna, J. M. López de Luzuriaga, Dalton Trans. 2007, 1969.

[7] E. J. Fernández, A. Laguna, J. M. López de Luzuriaga, Coord. Chem. Rev. 2005, 249, 1423.

[8] A. Laguna (Ed.), Modern Supramolecular Gold Chemistry, WileyVCH, Weinheim, 2008.

[9] E. J. Fernández, J. M. López de Luzuriaga, M. Monge, M. A. Rodríguez, O. Crespo, M. C. Gimeno, A. Laguna, P. G. Jones, Chem, Eur. J. 2000, 6, 636.

[10] V. W. W. Yam, E. C. C. Cheng, Chem. Soc. Rev. 2008, 37, 1806. 
[11] H. Schmidbaur, A. Schier, Chem. Soc. Rev. 2008, 37, 1931.

[12] S. Sculfort, P. Braunstein, Chem. Soc. Rev. 2011, 40, 2741.

[13] J. Forniés, A. Martín, in Metal Clusters in Chemistry (Eds.: P. Braunstein, L. A. Oro, P. R. Raithby), Wiley-VCH, Weinheim, 1999, vol. 1 ,pp. 417.

[14] J. Forniés, C. Fortuño, S. Ibáñez, A. Martín, Inorg. Chem. 2008, 47, 5978.

[15] J. Forniés, S. Fuertes, A. Martín, V. Sicilia, B. Gil, E. Lalinde, Dalton Trans. 2009, 2224.

[16] J. Forniés, S. Ibáñez, A. Martín, B. Gil, E. Lalinde, M. T. Moreno, Organometallics 2004, 23, 3963.

[17] J. Forniés, S. Ibáñez, A. Martín, M. Sanz, J. R. Berenguer, E. Lalinde, J. Torroba, Organometallics 2006, 25, 4331.

[18] J. R. Berenguer, A. Díez, J. Fernández, J. Forniés, A. García, B. Gil, E. Lalinde, M. T. Moreno, Inorg. Chem. 2008, 47, 7703.

[19] J. M. Casas, J. Forniés, S. Fuertes, A. Martín, V. Sicilia, Organometallics 2007, 26, 1674.

[20] W. Chen, F. Liu, T. Nishioka, K. Matsumoto, Eur. J. Inorg. Chem. 2003, 4234.

[21] A. Díez, J. Forniés, J. Gómez, E. Lalinde, A. Martín, M. T. Moreno, S. Sánchez, Dalton Trans. 2007, 3653.

[22] T. Yamaguchi, F. Yamazaki, T. Ito, J. Am. Chem. Soc. 1999, 121, 7405.

[23] T. Yamaguchi, F. Yamazaki, T. Ito, J. Am. Chem. Soc. 2001, 123, 743.

[24] M.-E. Moret, P. Chen, J. Am. Chem. Soc. 2009, 131, 5675.

[25] G. Kampf, P. J. S. Miguel, M. Willermann, A. Schneider, B. Lippert, Chem. Eur. J. 2008, 14, 6882.

[26] D. E. Janzen, L. F. Mehne, D. G. VanDerveer, G. J. Grant, Inorg. Chem. 2005, 44, 8182.

[27] S. A. Baudron, M. W. Hosseini, Chem. Commun. 2008, 4558.

[28] G.-Q. Yin, Q.-H. Wei, L.-Y. Zhang, Z.-N. Chen, Organometallics 2006, 25, 580.

[29] M.-E. Moret, P. Chen, Organometallics 2008, 27, 4903.

[30] L. R. Falvello, J. Forniés, R. Garde, A. García, E. Lalinde, M. T. Moreno, A. Steiner, M. Tomás, I. Usón, Inorg. Chem. 2006, 45, 2543.

[31] O. Crespo, A. Laguna, E. J. Fernández, J. M. López de Luzuriaga, P. G. Jones, M. Teichert, M. Monge, P. Pyykkö, N. Runeberg, M. Schütz, H. J. Werner, Inorg. Chem. 2000, 39, 4786.

[32] S. Fuertes, C. H. Woodall, P. R. Raithby, V. Sicilia, Organometallics 2012, 31, 4228.

[33] L. R. Falvello, J. Forniés, A. Martín, V. Sicilia, P. Villarroya, Organometallics 2002, 21, 4604.

[34] E. Alonso, J. Forniés, C. Fortuño, A. Martín, A. G. Orpen, Organometallics 2003, 22, 5011.

[35] F. D. Rochon, R. Melanson, Acta Cryst. Sect. C: Cryst. Struct. Commun. 1988, 44, 474.

[36] L. R. Falvello, J. Forniés, C. Fortuño, F. Durán, A. Martín, Organometallics 2002, 21, 2226.

[37] I. Ara, L. R. Falvello, J. Forniés, J. Gómez, E. Lalinde, R. I. Merino, I. Usón, J. Organomet. Chem. 2002, 663, 284.

[38] L. R. Falvello, J. Forniés, E. Lalinde, B. Menjón, M. A. García Monforte, M. T. Moreno, M. Tomás, Chem. Commun. 2007, 3838.

[39] J. Forniés, S. Ibáñez, E. Lalinde, A. Martín, M. T. Moreno, A. C. Tsipis, Dalton Trans. 2012, 41, 3439.

[40] P. T. Chou, Y. Chi, Chem. Eur. J. 2007, 13, 380.

[41] M. W. Cooke, G. S. Hanan, Chem. Soc. Rev. 2007, 36, 1466.

[42] R. C. Evans, P. Douglas, C. J. Wiscom, Coord. Chem. Rev. 2006, 250, 2093.

[43] E. Holder, B. M. W. Langeveld, U. S. Schubert, Adv. Mater. 2005, 17, 1109.

[44] M. D. McClenaghan, N. D. Leydet, Y. Maubert, M. T. Indelli, S. Campagna, Coord. Chem. Rev. 2005, 249, 1336.

[45] S. S. Sun, A. J. Lees, Coord. Chem. Rev. 2002, 230, 171.

[46] W. Y. Wong, Comments Inorg. Chem. 2005, 26, 39.

[47] M. H. V. Huynh, D. M. Dattelbaum, T. J. Meyer, Coord. Chem. Rev. 2005, 249, 457.

[48] A. Vogler, H. Kunkely, Top. Curr. Chem. 2001, 213, 143.

[49] P. Thanasekaran, R. T. Liao, Y. H. Liu, T. Rajendran, S. Rajagopal, K. L. Lu, Coord. Chem. Rev. 2005, 249, 1085.

[50] Coord. Chem. Rev. 2000, 208 (special issue), 1.

[51] B. Ma, P. I. Djurovich, M. E. Thompson, Coord. Chem. Rev. 2005, 249, 1501.

[52] S. Pérez, C. López, A. Caubet, R. Bosque, X. Solans, M. F. Bardía, A. Roig, E. Molins, Organometallics 2004, 23, 224.

[53] J. Forniés, V. Sicilia, J. M. Casas, A. Martín, J. A. López, C. Larraz, P. Borja, C. Ovejero, Dalton Trans. 2011, 40, 2898.

[54] R. Usón, J. Forniés, M. Tomás, I. Ara, J. M. Casas, A. Martín, J. Chem. Soc., Dalton Trans. 1991, 2253.
[55] L. R. Falvello, J. Forniés, A. Martín, V. Sicilia, P. Villarroya, Organometallics 2002, 21, 4604.

[56] I. Ara, J. Forniés, V. Sicilia, P. Villarroya, Dalton Trans. 2003, 4238.

[57] J. R. Berenguer, B. Gil, J. Fernández, J. Forniés, E. Lalinde, Inorg. Chem. 2009, 48, 5250.

[58] C. Mealli, F. Pichierri, L. Randaccio, E. Zangrando, M. Krumm, D. Holtenrich, B. Lippert, Inorg. Chem. 1995, 34, 3418.

[59] G. Aullón, S. Álvarez, Inorg. Chem. 1996, 3137.

[60] J. R. Berenguer, E. Lalinde, M. T. Moreno, S. Sánchez, J. Torroba, Inorg. Chem. 2012, 51, 11665.

[61] J. Forniés, J. Gómez, E. Lalinde, M. T. Moreno, Inorg. Chem. 2001, 40, 5415.

[62] S. Fuertes, S. K. Brayshaw, P. R. Raithby, S. Schiffers, M. R. Warren, Organometallics 2012, 31, 105.

[63] C. A. Hunter, J. K. M. Sanders, J. Am. Chem. Soc. 1990, 112, 5525.

[64] C. A. Hunter, Chem. Soc. Rev. 1994, 101.

[65] A. Díez, J. Forniés, A. García, E. Lalinde, M. T. Moreno, Inorg. Chem. 2005, 44, 2443.

[66] W. Lu, M. C. W. Chan, N. Zhu, C. M. Che, C. Li, Z. Hui, J. Am. Chem. Soc. 2004, 126, 7639.

[67] V. W. Yam, R. P. L. Tang, K. M. C. Wong, X. X. Lu, K. K. Cheung, N. Zhu, Chem. Eur. J. 2002, 8, 4066.

[68] S. J. Farley, D. L. Rochester, A. L. Thompson, J. A. K. Howard, J. A. Williams, Inorg. Chem. 2005, 44, 9690.

[69] M. Munakata, L. P. Wu, G. L. Ning, T. Kuroda-Sowa, M. Maekawa, Y. Suenaga, N. Maeno, J. Am. Chem. Soc. 1999, 121, 4968.

[70] M. Munakata, L. P. Wu, T. Kuroda-Sowa, M. Maekawa, Y. Suenaga, G. L. Ning, T. Kojima, J. Am. Chem. Soc. 1998, 120, 8610.

[71] M. Munakata, J. C. Zhong, T. Kuroda-Sowa, M. Maekawa, Y. Suenaga, M. Kasahara, H. Konaka, Inorg. Chem. 2001, 40, 7087.

[72] M. Munakata, L. P. Wu, T. Kuroda-Sowa, M. Maekawa, Y. Suenaga, T. Ohta, H. Konaka, Inorg. Chem. 2003, 42, 2553.

[73] W.-B. Yuan, R.-D. Yang, L. Tan, Trans. Met. Chem. 2004, 29, 380.

[74] F. A. Cotton, L. R. Falvello, R. Usón, J. Forniés, M. Tomás, J. M. Casas, I. Ara, Inorg. Chem. 1987, 26, 1366.

[75] R. Usón, J. Forniés, M. Tomás, J. M. Casas, F. A. Cotton, L. R. Falvello, R. Llusar, Organometallics 1988, 7, 2279.

[76] R. Usón, J. Forniés, M. Tomás, J. M. Casas, Angew. Chem. Int. Ed. 1989, 28, 748.

[77] J. Forniés, R. Navarro, M. Tomás, E. P. Urriolabeitia, Organometallics 1993, 12, 940.

[78] J. M. Casas, L. R. Falvello, J. Forniés, A. Martín, Inorg. Chem. 1996, 35, 7867.

[79] R. Usón, J. Forniés, L. R. Falvello, M. Tomás, J. M. Casas, A. Martín, Inorg. Chem. 1993, 32, 5212.

[80] A. Martín, A. G. Orpen, J. Am. Chem. Soc. 1996, 118, 1464.

[81] J. C. Zhong, M. Munakata, T. Kuroda-Sowa, M. Maekawa, Y. Suenaga, H. Konaka, Inorg. Chem. 2001, 40, 3191.

[82] M. Wen, M. Maekawa, M. Munakata, Y. Suenaga, T. Kuroda-Sowa, Inorg. Chim. Acta 2002, 338, 111.

[83] S. Q. Liu, T. Kuroda-Sowa, H. Konaka, Y. Suenaga, M. Maekawa, T. Mizutani, G. L. Ning, M. Munakata, Inorg. Chem. 2005, 44, 1031.

[84] Y.-B. Dong, Y. Geng, J.-P. Ma, R.-Q. Huang, Inorg. Chem. 2005, 44, 1693.

[85] Y.-B. Dong, G.-X. Jin, X. Zhao, B. Tang, R.-Q. Huang, M. D. Smith, K. E. Stitzer, H.-C. zur Loye, Organometallics 2004, 23, 1604.

[86] Y.-B. Dong, X. Zhao, G.-X. Jin, R.-Q. Huang, M. D. Smith, Eur. J. Inorg. Chem. 2003, 4017.

[87] T. Brasey, A. Buryak, R. Scopelliti, K. Severin, Eur. J. Inorg. Chem. 2004, 964.

[88] M. Munakata, L. P. Wu, G. L. Ning, Coord. Chem. Rev. 2000, 198, 171.

[89] A. P. Côté, G. K. H. Shimizu, Inorg. Chem. 2004, 43, 6663.

[90] X.-M. Lin, Y. Ying, L. Chen, H.-C. Fang, Z.-Y. Zhou, Q.-G. Zhan, Y.-P. Cai, Inorg. Chem. Commun. 2009, 12, 316.

[91] R. M. Hellyer, D. S. Larsen, S. Brooker, Eur. J. Inorg. Chem. 2009, 2009, 1162

[92] L.-C. Song, G.-X. Jin, L.-Q. Zhao, H.-T. Wang, W.-X. Zhang, Q.-M. Hu, Eur. J. Inorg. Chem. 2009, 2009, 419.

[93] R. P. Feazell, C. E. Carson, K. K. Klausmeyer, Inorganic Chemistry 2005, 45, 935.

[94] N. Sadhukhan, S. K. Patra, K. Sana, J. K. Bera, Organometallics 2006, 25, 2914.

[95] M. A. M. Abu-Youssef, R. Dey, Y. Gohar, A. a. A. Massoud, L. Öhrström, V. Langer, Inorg. Chem. 2007, 46, 5893.

[96] A. Díez, J. Forniés, S. Fuertes, E. Lalinde, C. Larraz, J. A. López, A. Martín, M. T. Moreno, V. Sicilia, Organometallics 2009, 28, 1705.

[97] A. Díez, J. Forniés, C. Larraz, E. Lalinde, J. A. López, A. Martín, M. T. Moreno, V. Sicilia, Inorg. Chem. 2010, 49, 3239. 
[98] F. M. Hwang, H. Y. Chen, P. S. Chen, C. S. Liu, Y. Chi, C. F. Shu, F. L. Wu, P. T. Chou, S. M. Peng, G. H. Lee, Inorg. Chem. 2005, 44 1344.

[99] J. Brooks, Y. Babayan, S. Lamansky, P. I. Djurovich, I. Tsyba, K. Bau, M. E. Thompson, Inorg. Chem. 2002, 41, 3055.

[100] S. D. Cummings, R. Eisenberg, J. Am. Chem. Soc. 1996, 118, 1949.

[101] J. A. G. Williams, Chem. Soc. Rev. 2009, 38, 1783.

[102] J. A. G. Williams, Top. Curr. Chem. 2007, 281, 205.

[103] E. J. Maslowsky, Vibrational Spectra of Organometallic Compounds, Wiley, New York, 1977.

[104] 'CrysAlis RED Program for X-ray CCD camera data reduction', Oxford Diffraction, Oxford, UK, 2004

[105] G. M. Sheldrick, 'SHELXL-97, program for crystal structure refinement', University of Gottingen, Germany, 1997.

[106] A. D. Becke, J. Chem. Phys. 1993, 98, 5648.

[107] C. T. Lee, W. T. Yang, R. G. Parr, Phys. Rev. B 1988, 37, 785.
[108] Y. Zhao, D. G. Truhlar, Theor. Chem. Acc. 2008, 120, 215.

[109] M. J. Frisch et al., 'Gaussian 09, Revision A.02'., Gaussian, Inc., Wallinford CT, 2009.

[110] D. Andrae, U. Haussermann, M. Dolg, H. Stoll, H. Preuss, Theoretica Chimica Acta 1990, 77, 123.

[111] R. Ditchfield, W. J. Herhe, J. A. Pople, J. Chem. Phys. 1971, 54, 724

[112] P. C. Hariharan, J. A. Pople, Theoretica Chimica Acta 1973, 28, 213.

[113] U. Varetto, 'MOLEKEL 5.4', Swiss National Supercomputing Centre, Lugano (Switzerland), 2009. 
Entry for the Table of Contents

((Key Topic))

Trimetallic $\left[\left\{\mathrm{Pt}\left(\mathrm{C}_{6} \mathrm{~F}_{5}\right)(\mathrm{bzq}) \mathrm{L}\right\}_{2} \mathrm{Ag}\right]^{+}$or bimetallic $\quad\left[\left(\mathrm{C}_{6} \mathrm{~F}_{5}\right)(\mathrm{bzq})\left(\mathrm{PPh}_{3}\right) \mathrm{Pt}\right.$ $\left.\mathrm{Ag}\left(\mathrm{pyPh}_{2}\right)\right]^{+}$clusters containing Pt-Ag bonds have been prepared from $\left[\operatorname{Pt}\left(\mathrm{C}_{6} \mathrm{~F}_{5}\right)(\mathrm{bzq}) \mathrm{L}\right] \quad(\mathrm{bzq}=7,8-$ benzoquinolinate). All these complexes have luminescent properties which have been studied and interpreted with the help of TD-DFT calculations.

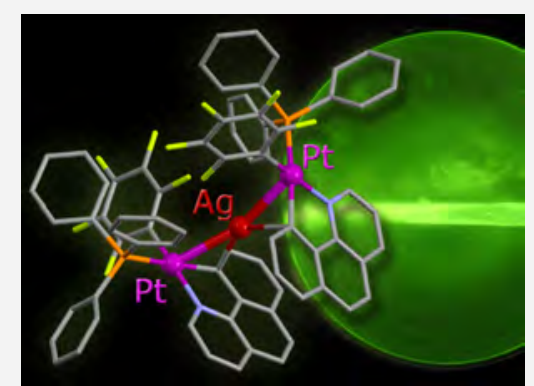

Antonio Martín,* Úrsula Belío, Sara Fuertes and Violeta Sicilia........ Page No. - Page No.

Luminescent Pt-Ag Clusters based in Neutral Benzoquinolate

Cyclometalated Platinum Complexes

Keywords: Donor-acceptor systems, heterometallic complexes, Luminescence, metal-metal interactions, pi interactions, X-ray diffraction. 
SUPPORTING INFORMATION 
Table S1. Absorption data for $\mathbf{1}$ to $\mathbf{1 1}$ in solutions $10^{-4} \mathrm{M}$ at room temperature.

\begin{tabular}{|c|c|c|}
\hline Compound & Solvent & $\lambda_{\mathrm{abs}} / \mathrm{nm}\left(10^{3} \& \mathrm{M}^{-1} \mathrm{~cm}^{-1}\right)$ \\
\hline \multirow[t]{2}{*}{1} & Toluene & $\begin{array}{l}\text { 288(9.3), 300(8.4), 314(8.2), 338(5.3), 372(2.7), 412(1.5), } \\
\text { 432(1.6) }\end{array}$ \\
\hline & $\mathrm{CH}_{2} \mathrm{Cl}_{2}$ & 300(7.3), 346(2.4), 400(1.4) \\
\hline \multirow{5}{*}{2} & Toluene & 268(12.1), 278(12.6), 306(15.2), 362(3.1), 396(2.1), 412(2.1) \\
\hline & THF & 302(20.5), 356(4.1), 388(2.7), 404(2.8) \\
\hline & $\mathrm{CH}_{2} \mathrm{Cl}_{2}$ & 302(6.9), 352(1.4), 388(0.9), 402(1.0) \\
\hline & DMF & 270(21.7), 288(19.8), 350(3.0),384(2.0), 398(2.1) \\
\hline & NCMe & 298(15.5), 352(3.0), 382(2.1), 394(2.2) \\
\hline \multirow{5}{*}{3} & Toluene & 288(26.6), 302(24.6),340(7.8), 370(4.1), 416(2.3), 432(2.3) \\
\hline & THF & 300(18.0), 334(5.1), 370(2.6), 416(1.0), 430(0.6) \\
\hline & $\mathrm{CH}_{2} \mathrm{Cl}_{2}$ & 300(6.2), 334(2.3), 370(1.0), 402(0.7) \\
\hline & DMF & 268(22.0), 296(16.2), 336(7.8), 360(3.8), 412(2.2) \\
\hline & NCMe & 294(16.4), 332(8.0), 358(3.9), 412(2.2) \\
\hline \multirow{5}{*}{4} & Toluene & 288(10.2), 306(9.3), 358(2.3), 398(1.5), 410(1.6) \\
\hline & THF & 278(15.6), 292(14.2), 304(13.4), 352(3.8), 398(2.4) \\
\hline & $\mathrm{CH}_{2} \mathrm{Cl}_{2}$ & 304(7.8), 320(5.3), 354(1.6), 400(1.4) \\
\hline & DMF & 304(8.5), 326(6.3), 362(2.6), 408(1.7) \\
\hline & NCMe & 302(14.4), 320(10.3), 348(3.7), 388(2.5), 400(2.6) \\
\hline \multirow{5}{*}{5} & Toluene & 286(22.0), 306(8.9), 356(3.3), 372 (3.1), 400(1.2) \\
\hline & 2-Me-THF & 282(11.0), 304(16.2), 330(8.9), 356(3.8), 392(2.8), 404(3.0) \\
\hline & $\mathrm{CH}_{2} \mathrm{Cl}_{2}$ & 304(11.4), 350(3.0), 394(2.0), 406(2.1) \\
\hline & $\mathrm{DMF}$ & 266(12.1), 306(9.9), 334(7.4), 358(3.5), 412(2.1) \\
\hline & NCMe & 302(22.8), 348(3.7), 390(2.5), 400(2.6) \\
\hline 6 & $\mathrm{CH}_{2} \mathrm{Cl}_{2}$ & 284(4.6), 330(2.1),390(0.9), 406(0.8) \\
\hline 7 & $\mathrm{CH}_{2} \mathrm{Cl}_{2}$ & 300(6.9), 356(1.3), 398(1.0) \\
\hline 8 & $\mathrm{CH}_{2} \mathrm{Cl}_{2}$ & 298(8.6), 332(3.7), 408(1.2) \\
\hline 9 & $\mathrm{CH}_{2} \mathrm{Cl}_{2}$ & 300(8.0), 326(4.2), 354(1.7), 402(1.4) \\
\hline 10 & $\mathrm{CH}_{2} \mathrm{Cl}_{2}$ & 298(5.3), 336(2.4), 392(0.9), 406(1.0) \\
\hline 11 & $\mathrm{CH}_{2} \mathrm{Cl}_{2}$ & 300(5.6), 358(0.7), 400(5.6) \\
\hline
\end{tabular}


Table S2. DFT-Optimized coordinates of $\left[\mathrm{Pt}\left(\mathrm{C}_{6} \mathrm{~F}_{5}\right)(\mathrm{bzq})\left(\mathrm{PPh}_{3}\right)\right](2)$

\begin{tabular}{|c|c|c|c|}
\hline \multicolumn{2}{|c|}{ Center } & $\begin{array}{c}\text { Coordinates } \\
Y\end{array}$ & $\begin{array}{c}\text { (Angstroms) } \\
Z\end{array}$ \\
\hline $\mathrm{Pt}$ & $\odot .607532000$ & -0.394177000 & ๑.01990400९ \\
\hline$P$ & $-\odot .807681000$ & 1.549342000 & ๑.037913000 \\
\hline $\mathrm{F}$ & -1.257802000 & -1.402798000 & -2.361714000 \\
\hline $\mathrm{F}$ & -3.349378000 & -3.103587000 & -2.409414000 \\
\hline $\mathrm{F}$ & -4.272764001 & -4.229008001 & $-\odot .092406000$ \\
\hline$F$ & -3.068124000 & -3.617466000 & 2.285769000 \\
\hline $\mathrm{F}$ & $-\odot .977402 \odot \odot \odot$ & $-1.91753800 \odot$ & $2.35971900 \odot$ \\
\hline $\mathrm{N}$ & $2.53524900 \odot$ & $\odot .62344900 \odot$ & ๑.0०816200९ \\
\hline C & -1.012751000 & -1.608530000 & $-\odot .00121900 \odot$ \\
\hline C & -1.667781000 & -1.943076000 & -1.184726000 \\
\hline C & -2.753789000 & -2.813694000 & -1.240703000 \\
\hline C & -3.226750000 & -3.388206000 & $-\odot .06379500 \odot$ \\
\hline C & -2.608624000 & -3.076474000 & 1.144314000 \\
\hline C & -1.525500000 & -2.199492000 & 1.152124000 \\
\hline C & 2.805340000 & 1.930606000 & $-\odot .0061080 \odot \odot$ \\
\hline C & 4.112659000 & 2.439152000 & $-\odot . \odot \odot 5248 \odot \odot \odot$ \\
\hline C & 5.179009001 & 1.558253000 & $\odot .00847500 \odot$ \\
\hline C & 4.932980001 & $\odot .171511000$ & 0.014163000 \\
\hline C & 5.968267001 & $-\odot .823221000$ & ๑.018753000 \\
\hline C & 5.659475001 & -2.152085000 & 0.011091000 \\
\hline C & 4.297819001 & -2.611624000 & $-\odot .0 \odot 26420 \odot \odot$ \\
\hline C & 3.951188000 & -3.979206000 & $-0.02372000 \odot$ \\
\hline C & 2.616148000 & -4.344142001 & -0.045300000 \\
\hline C & $1.58815900 \odot$ & -3.376354000 & -0.042133000 \\
\hline C & 1.870031000 & $-2.01196 \odot \odot \odot \odot$ & -0.014343000 \\
\hline C & 3.247586000 & -1.652717000 & ๑.๑०151600९ \\
\hline C & 3.581128000 & $-\odot .262087000$ & ๑.01110000९ \\
\hline C & $-\odot .725406000$ & $2.55752200 \odot$ & 1.579626000 \\
\hline C & 0.253846000 & 2.256137 & 2.538441000 \\
\hline C & 0.3 & 2.992925 & 3.7227 \\
\hline C & -0.561765 & 4.03347 & 3.963 \\
\hline C & -1.55 & 4.3305 & 3.022893000 \\
\hline C & -1.63 & 3.594062 & 1.841896000 \\
\hline C & -0.360486000 & $2.68202400 \odot$ & -1.351326000 \\
\hline C & - ๑ . ๑41935००९ & 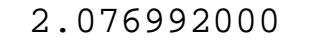 & -2.581305000 \\
\hline C & $\odot .30517700 \odot$ & $2.85855700 \odot$ & -3.683807000 \\
\hline C & ๑.358933000 & 4. 249910001 & -3.569107000 \\
\hline C & ๑.05762500९ & 4.857058001 & -2.349018000 \\
\hline C & $-\odot .30446200 \odot$ & 4.079730000 & -1.245952000 \\
\hline C & -2.625367000 & 1.293588000 & $-\odot .159012000$ \\
\hline C & -3.312661000 & 1.627351000 & -1.333150000 \\
\hline C & -4.680713001 & $1.36569900 \odot$ & -1.448773000 \\
\hline C & -5.374152001 & $\odot .76995400 \odot$ & $-\odot .395950000$ \\
\hline C & -4.695552001 & 0.434731000 & 0.779152000 \\
\hline C & -3.330878000 & ๑.691387000 & $\odot .89721700 \odot$ \\
\hline H & 1.958261000 & 2.604348000 & $-\odot .027553000$ \\
\hline H & 4.263479001 & 3.513426000 & -0.016640000 \\
\hline H & 6.203362001 & 1.922951000 & ๑.010613000 \\
\hline H & 7.003851001 & -0.493162000 & 0.025333000 \\
\hline $\mathrm{H}$ & 6.454003001 & -2.894798000 & 0.012471000 \\
\hline
\end{tabular}




\begin{tabular}{|c|c|c|c|}
\hline $\mathrm{H}$ & 4.735318001 & -4.732307001 & -0.025755000 \\
\hline $\mathrm{H}$ & 2.348768000 & -5.398227001 & -0.065011000 \\
\hline $\mathrm{H}$ & ๑.558963000 & -3.719472000 & -0.063027000 \\
\hline $\mathrm{H}$ & $\odot .933972000$ & 1.427525000 & 2.363432000 \\
\hline $\mathrm{H}$ & 1.094069000 & 2.743337000 & 4.459821001 \\
\hline $\mathrm{H}$ & $-\odot .5 \odot \odot 428 \odot \odot \odot$ & 4.603837001 & 4.886517001 \\
\hline $\mathrm{H}$ & $-2.2637630 \odot \odot$ & 5.129357001 & $3.21367600 \odot$ \\
\hline $\mathrm{H}$ & $-2.429480 \odot \odot \odot$ & 3.813318000 & 1.130039000 \\
\hline $\mathrm{H}$ & $-\odot . \odot 655630 \odot \odot$ & $\odot .993619000$ & -2.667442000 \\
\hline $\mathrm{H}$ & $\odot .543228000$ & 2.377924000 & -4.628754001 \\
\hline $\mathrm{H}$ & ๑. 638501000 & 4.857209001 & -4.425810001 \\
\hline $\mathrm{H}$ & 0.101732000 & 5.938694001 & -2.252239000 \\
\hline $\mathrm{H}$ & -0.533437000 & 4.566672001 & -0.303475000 \\
\hline $\mathrm{H}$ & -2.787034000 & 2.090661000 & -2.161441000 \\
\hline $\mathrm{H}$ & -5.200595001 & 1.629398000 & -2.365833000 \\
\hline $\mathrm{H}$ & -6.436982001 & $\odot .56416900 \odot$ & -0.489013000 \\
\hline $\mathrm{H}$ & -5.227207001 & $-\odot .0334210 \odot \odot$ & $1.60300200 \odot$ \\
\hline $\mathrm{H}$ & $-2.81276800 \odot$ & $\odot .42045900 \odot$ & 1.812818000 \\
\hline
\end{tabular}


Table S3. DFT-Optimized coordinates of $\left[\mathrm{Pt}\left(\mathrm{C}_{6} \mathrm{~F}_{5}\right)(\mathrm{bzq})(\mathrm{tht})\right](4)$

\begin{tabular}{|c|c|c|c|}
\hline \multirow[t]{2}{*}{ Center } & \multicolumn{3}{|c|}{ Coordinates (Angstroms) } \\
\hline & $x$ & $\mathrm{Y}$ & Z \\
\hline $\mathrm{Pt}$ & -0.358287 & ๑. 388816 & 0.032677 \\
\hline $\mathrm{S}$ & 0.620091 & 2.659090 & 0.104656 \\
\hline $\mathrm{F}$ & 1.621091 & -0.451672 & -2.359258 \\
\hline $\mathrm{F}$ & 4.027442 & -1.656122 & -2.350300 \\
\hline$F$ & 5.228893 & -2.339600 & $\odot .011223$ \\
\hline$F$ & 3.973697 & -1.786211 & 2.378698 \\
\hline$F$ & 1.570080 & -0.575837 & 2.399174 \\
\hline $\mathrm{N}$ & -2.393570 & 1.105585 & ๑.056206 \\
\hline C & 1.472541 & -0.482886 & ๑. . 019428 \\
\hline C & 2.159505 & -0.782165 & -1.157322 \\
\hline C & 3.409278 & -1.399688 & -1.185842 \\
\hline C & 4.024853 & -1.748726 & 0.013795 \\
\hline C & 3.381687 & -1.466122 & 1. 216628 \\
\hline C & 2.133178 & -0.846118 & 1.193771 \\
\hline C & -2.847197 & 2.358243 & $\odot .113619$ \\
\hline $\mathrm{H}$ & -2.097909 & 3.141369 & $\odot .156137$ \\
\hline C & -4.216918 & 2.664480 & $\odot .122172$ \\
\hline $\mathrm{H}$ & -4.529190 & 3.702365 & $\odot .169850$ \\
\hline C & -5.140917 & 1.635120 & ๑.069885 \\
\hline $\mathrm{H}$ & -6.207660 & 1.845146 & 0.074810 \\
\hline C & -4.693266 & ๑. 300172 & 0.011431 \\
\hline C & -5.561010 & -0.842802 & -0.043109 \\
\hline $\mathrm{H}$ & -6.635505 & -0.679489 & -0.041853 \\
\hline C & -5.048783 & -2.107132 & - ๑. 094841 \\
\hline $\mathrm{H}$ & -5.719254 & -2.962443 & $-\odot .135512$ \\
\hline C & -3.631766 & -2.352618 & $-\odot .095839$ \\
\hline C & -3.071414 & -3.647194 & -0.145360 \\
\hline $\mathrm{H}$ & -3.724848 & -4.514981 & -0.186697 \\
\hline C & -1.694881 & -3.796392 & -0.140049 \\
\hline $\mathrm{H}$ & -1.264555 & -4.794419 & -0.177979 \\
\hline C & -0.830275 & -2.680950 & -0.086423 \\
\hline $\mathrm{H}$ & 0.240637 & -2.854443 & -0.084026 \\
\hline C & -1.329283 & $-1 \cdot 381752$ & -0.037652 \\
\hline C & -2.747177 & -1.242582 & -0.043616 \\
\hline C & -3.293345 & ๑.076394 & $\odot .007927$ \\
\hline C & 1.711034 & 2.908859 & -1.380730 \\
\hline $\mathrm{H}$ & 1.826161 & 1.948634 & -1.885523 \\
\hline $\mathrm{H}$ & 1.207905 & 3.607933 & -2.052908 \\
\hline C & 3.038339 & 3.444250 & -0.830241 \\
\hline $\mathrm{H}$ & 3.839380 & 3.306080 & -1.565089 \\
\hline $\mathrm{H}$ & 2.954742 & 4.519739 & -0.629310 \\
\hline C & 3.320617 & 2.684401 & 0.473588 \\
\hline $\mathrm{H}$ & 3.579669 & 1.644840 & ๑. 247914 \\
\hline $\mathrm{H}$ & 4.155127 & 3.124554 & 1.030975 \\
\hline C & 2.036160 & 2.721579 & 1. 311877 \\
\hline $\mathrm{H}$ & 1.938492 & 3.658247 & 1.867879 \\
\hline $\mathrm{H}$ & 1.940158 & 1.881426 & 2.000182 \\
\hline
\end{tabular}


Table S4. DFT-Optimized coordinates of $\left[\mathrm{Pt}\left(\mathrm{C}_{6} \mathrm{~F}_{5}\right)(\mathrm{bzq})(\mathrm{MeCN})\right](5)$

\begin{tabular}{|c|c|c|c|}
\hline & & dinates & stroms ) \\
\hline & $\mathrm{X}$ & Y & Z \\
\hline$\overline{\mathrm{Pt}}$ & -0.209590 & 0.568715 & 0.000565 \\
\hline $\mathrm{F}$ & 1.829557 & -0.105003 & 2.379057 \\
\hline $\mathrm{F}$ & 4.387986 & $-\odot .951870$ & 2.365788 \\
\hline $\mathrm{F}$ & 5.694502 & -1.369830 & $-\odot .0 \odot \odot 215$ \\
\hline $\mathrm{F}$ & 4. 397808 & -0.919962 & -2.365817 \\
\hline $\mathrm{F}$ & 1.839424 & $-\odot .072731$ & -2.378219 \\
\hline $\mathrm{N}$ & -2.305334 & 1.047128 & $\odot .001135$ \\
\hline $\mathrm{N}$ & $\odot .494825$ & 2.554100 & $\odot .0 \odot 4441$ \\
\hline C & 1.720145 & $-\odot .066389$ & 0.000322 \\
\hline C & 2.426528 & $-\odot .299358$ & 1.179623 \\
\hline C & 3.749778 & $-\odot .738476$ & 1.202281 \\
\hline C & 4.418772 & -0.952113 & $-\odot . \odot \odot \odot \odot 62$ \\
\hline C & 3.754779 & -0.722271 & -1.202186 \\
\hline C & 2.431431 & $-\odot .283492$ & -1.179038 \\
\hline C & -2.894902 & 2.242201 & 0.003174 \\
\hline $\mathrm{H}$ & -2.234406 & 3.102868 & 0.004321 \\
\hline C & -4.290100 & 2.392095 & ๑.003784 \\
\hline $\mathrm{H}$ & -4.719873 & 3.388265 & $\odot .0 \odot 546 \odot$ \\
\hline C & -5.091083 & 1.261835 & $\odot .0 \odot 2211$ \\
\hline $\mathrm{H}$ & -6.174697 & 1.350828 & $\odot .0 \odot 2645$ \\
\hline C & -4.496302 & -0.015760 & -0.000029 \\
\hline C & -5.225663 & -1.252991 & -0.001921 \\
\hline $\mathrm{H}$ & -6.311899 & -1.216357 & $-\odot .001482$ \\
\hline C & -4.568977 & -2.450175 & -0.004301 \\
\hline $\mathrm{H}$ & -5.135855 & -3.378332 & $-\odot .0 \odot 5784$ \\
\hline C & -3.132742 & -2.530765 & $-\odot . \odot \odot 5 \odot \odot 7$ \\
\hline C & -2.425472 & -3.751871 & $-\odot .0 \odot 7767$ \\
\hline $\mathrm{H}$ & -2.972576 & -4.691267 & $-\odot .009362$ \\
\hline C & -1.040437 & -3.737867 & $-\odot .008538$ \\
\hline $\mathrm{H}$ & $-\odot .496486$ & -4.679564 & $-\odot .010806$ \\
\hline C & -0.311357 & -2.528758 & $-\odot .006422$ \\
\hline $\mathrm{H}$ & 0.772486 & -2.575802 & $-\odot .007230$ \\
\hline C & -0.956588 & -1.293708 & -0.003367 \\
\hline C & -2.382787 & -1.325109 & $-\odot .0 \odot 2921$ \\
\hline C & -3.080133 & -0.078687 & -0.000512 \\
\hline C & ๑.996772 & 3.596682 & $\odot .006351$ \\
\hline C & 1.647745 & 4.901422 & $\odot .008623$ \\
\hline $\mathrm{H}$ & 1.305344 & 5.494189 & ๑. 862718 \\
\hline $\mathrm{H}$ & 1.417362 & 5.440805 & $-\odot .915584$ \\
\hline $\mathrm{H}$ & 2.732275 & 4.771858 & ๑.080842 \\
\hline
\end{tabular}


Table S5. DFT-Optimizedcoordinates of $\left[\left\{\mathrm{Pt}\left(\mathrm{C}_{6} \mathrm{~F}_{5}\right)(\mathrm{bzq})(\mathrm{tht})\right\}_{2} \mathrm{Ag}\right]^{+}(\mathbf{9})$

\begin{tabular}{|c|c|c|c|}
\hline Center & Coor & nates (Ang & roms ) \\
\hline & $\mathrm{X}$ & Y & Z \\
\hline$\overline{\mathrm{Pt}}$ & -2.733908 & -0.502044 & $\odot .393030$ \\
\hline $\mathrm{Pt}$ & 2.733649 & -0.502407 & -0.393049 \\
\hline $\mathrm{Ag}$ & -0.000197 & 0.151714 & -0.000319 \\
\hline $\mathrm{s}$ & -4.311316 & -0.809305 & -1.472865 \\
\hline S & 4.310099 & -0.809931 & 1.473732 \\
\hline $\mathrm{F}$ & -4.915223 & 1.009953 & 1.997873 \\
\hline $\mathrm{F}$ & -5.506970 & 3.607299 & 2.305979 \\
\hline $\mathrm{F}$ & -4.056210 & 5.509829 & 1.025999 \\
\hline $\mathrm{F}$ & -1.989173 & 4.774958 & $-\odot .578787$ \\
\hline $\mathrm{F}$ & -1.374684 & 2.205397 & $-\odot .918146$ \\
\hline $\mathrm{F}$ & 1.374641 & 2.205555 & $\odot .916858$ \\
\hline $\mathrm{F}$ & 1.990215 & 4.774879 & $\odot .577668$ \\
\hline $\mathrm{F}$ & 4.058491 & 5.508925 & -1.025854 \\
\hline $\mathrm{F}$ & 5.509412 & 3.605802 & -2.304813 \\
\hline $\mathrm{F}$ & 4.916593 & 1.008679 & -1.996881 \\
\hline $\mathrm{N}$ & -2.202099 & -2.600107 & $\odot .497807$ \\
\hline $\mathrm{N}$ & 2.201377 & -2.600377 & $-\odot .497803$ \\
\hline C & -3.127252 & 1.486121 & $\odot .526215$ \\
\hline C & -4.166806 & 1.915816 & 1.345776 \\
\hline C & -4.498661 & 3.253596 & 1.525380 \\
\hline C & -3.758332 & 4.231996 & $\odot .870270$ \\
\hline C & -2.701170 & 3.852966 & ๑. 052521 \\
\hline C & -2.416310 & 2.501021 & -0.100233 \\
\hline C & -2.647680 & -3.616763 & $-\odot .230295$ \\
\hline C & -2.239196 & -4.938627 & $-\odot . \odot \odot 7696$ \\
\hline C & -1.324865 & -5.198800 & $\odot .989945$ \\
\hline C & $-\odot .816111$ & -4.139101 & 1.762515 \\
\hline C & $\odot .153572$ & -4.302735 & 2.802408 \\
\hline C & 0.603277 & -3.232120 & 3.512223 \\
\hline C & 0.121140 & -1.907355 & 3.253163 \\
\hline C & $\odot .554331$ & -0.778724 & 3.980663 \\
\hline C & ๑.041795 & 0.468669 & 3.694415 \\
\hline C & $-\odot .910029$ & ๑.648889 & 2.668328 \\
\hline C & -1.360454 & $-\odot .428815$ & 1.905797 \\
\hline C & $-\odot .831546$ & -1.715126 & 2.228596 \\
\hline C & -1.290308 & -2.842614 & 1.483627 \\
\hline C & 3.127901 & 1.485566 & -0.526371 \\
\hline C & 2.416878 & 2.500755 & ๑. 099556 \\
\hline C & 2.702273 & 3.852583 & -0.053127 \\
\hline C & 3.760086 & 4.231197 & $-\odot .870241$ \\
\hline C & 4.500488 & 3.252509 & -1.524818 \\
\hline C & 4.168087 & 1.914839 & -1.345322 \\
\hline C & 2.646660 & -3.617136 & ๑.230327 \\
\hline C & 2.237939 & -4.938920 & $\odot .0 \odot 7652$ \\
\hline C & 1.323625 & -5.198887 & $-\odot .990051$ \\
\hline C & $\odot .815187$ & -4.139071 & -1.762679 \\
\hline C & $-\odot .154466$ & -4.302482 & -2.802633 \\
\hline C & -0.603835 & -3.231767 & -3.512518 \\
\hline C & -0.121311 & -1.907137 & -3.253512 \\
\hline C & $-\odot .554 \odot 82$ & -0.778417 & -3.981128 \\
\hline
\end{tabular}




\begin{tabular}{|c|c|c|c|}
\hline C & -0.041200 & 0.468837 & -3.694909 \\
\hline$C$ & 0.910614 & $\odot .648830$ & -2.668765 \\
\hline C & 1.360701 & -0.428976 & -1.906188 \\
\hline C & 0.831368 & -1.715138 & -2.228893 \\
\hline C & 1. 289689 & -2.842704 & -1.483780 \\
\hline C & -4.077955 & $\odot .592857$ & -2.659881 \\
\hline C & -5.156163 & 1.610723 & -2.321734 \\
\hline C & -6.404771 & 0.814868 & -1.965665 \\
\hline C & -5.992164 & -0.231639 & -0.939333 \\
\hline C & 4.076959 & 0.592768 & 2.660137 \\
\hline C & 5.156051 & 1.609815 & 2.322343 \\
\hline C & 6.404305 & 0.813063 & 1.967025 \\
\hline C & 5.991452 & -0.233311 & 0.940657 \\
\hline $\mathrm{H}$ & -3.355615 & -3.375780 & -1.022659 \\
\hline $\mathrm{H}$ & -2.649175 & -5.733896 & -0.625043 \\
\hline $\mathrm{H}$ & -0.989987 & -6.216916 & 1.191023 \\
\hline $\mathrm{H}$ & 0.518489 & -5.307063 & 3.017073 \\
\hline $\mathrm{H}$ & 1.336558 & -3.368763 & 4.307058 \\
\hline $\mathrm{H}$ & 1.287691 & -0.908495 & 4.776867 \\
\hline $\mathrm{H}$ & 0.369805 & 1.334789 & 4.267486 \\
\hline $\mathrm{H}$ & -1.292569 & 1.652029 & 2.479668 \\
\hline $\mathrm{H}$ & 3.354498 & -3.376307 & 1.022823 \\
\hline $\mathrm{H}$ & 2.647689 & -5.734278 & 0.625036 \\
\hline $\mathrm{H}$ & 0.988486 & -6.216919 & -1.191118 \\
\hline $\mathrm{H}$ & -0.519632 & -5.306720 & -3.017295 \\
\hline $\mathrm{H}$ & -1.337123 & -3.368234 & -4.307375 \\
\hline $\mathrm{H}$ & -1.287415 & $-\odot .908008$ & -4.777384 \\
\hline $\mathrm{H}$ & $-\odot .368906$ & 1.335019 & -4.268059 \\
\hline $\mathrm{H}$ & 1.293452 & 1.651859 & -2.480131 \\
\hline $\mathrm{H}$ & -3.051390 & 0.962697 & -2.563571 \\
\hline $\mathrm{H}$ & -4.213247 & 0.176108 & -3.665846 \\
\hline $\mathrm{H}$ & -4.839116 & 2.222552 & -1.464087 \\
\hline $\mathrm{H}$ & -5.326135 & 2.286601 & -3.169246 \\
\hline $\mathrm{H}$ & -6.802604 & 0.321863 & -2.864494 \\
\hline $\mathrm{H}$ & -7.200718 & 1.451569 & -1.560144 \\
\hline $\mathrm{H}$ & -6.651810 & -1.104477 & -0.914279 \\
\hline $\mathrm{H}$ & -5.906398 & 0.178828 & ๑. 071694 \\
\hline $\mathrm{H}$ & 3.050721 & 0.963285 & 2.563013 \\
\hline $\mathrm{H}$ & 4.211321 & 0.176276 & 3.666332 \\
\hline $\mathrm{H}$ & 4.839864 & 2. 221701 & 1.464418 \\
\hline $\mathrm{H}$ & 5.326043 & 2.285745 & 3.169807 \\
\hline $\mathrm{H}$ & 6.801391 & 0.319926 & 2.866109 \\
\hline $\mathrm{H}$ & 7.200859 & 1.449176 & 1.561770 \\
\hline $\mathrm{H}$ & 6.650611 & -1.106526 & ๑.915896 \\
\hline $\mathrm{H}$ & 5.906238 & 0.177141 & -0.070421 \\
\hline
\end{tabular}


Table S6. DFT-Optimized coordinates of $\left[\left\{\mathrm{Pt}\left(\mathrm{C}_{6} \mathrm{~F}_{5}\right)(\mathrm{bzq})(\mathrm{MeCN})\right\}_{2} \mathrm{Ag}\right]^{+}(\mathbf{1 0})$

\begin{tabular}{|c|c|c|c|}
\hline Center & $\mathrm{Co}$ & dinates (An & troms) \\
\hline & $\mathrm{X}$ & $Y$ & Z \\
\hline$\overline{\mathrm{Pt}}$ & -2.426815 & 1.263754 & 0.220613 \\
\hline $\mathrm{Pt}$ & 2.104053 & -1.711161 & -0.673664 \\
\hline $\mathrm{Ag}$ & 0.229068 & 0.093582 & 0.366461 \\
\hline $\mathrm{F}$ & -3.671777 & 1.135523 & 3.136166 \\
\hline $\mathrm{F}$ & -4.083746 & -0.900438 & 4.833018 \\
\hline $\mathrm{F}$ & -3.393986 & -3.429084 & 4.138599 \\
\hline $\mathrm{F}$ & -2.292679 & -3.907061 & 1.693181 \\
\hline $\mathrm{F}$ & -1.901591 & -1.902486 & $-\odot .029242$ \\
\hline $\mathrm{F}$ & 2.442534 & $-\odot .585245$ & 2.276598 \\
\hline $\mathrm{F}$ & 3.906656 & 1.421654 & 3.282223 \\
\hline $\mathrm{F}$ & 5.479236 & 2.921207 & 1.658554 \\
\hline $\mathrm{F}$ & 5.690748 & 2.293932 & $-\odot .975384$ \\
\hline $\mathrm{F}$ & 4.306877 & $\odot .238650$ & -1.995012 \\
\hline C & -2.762224 & $-\odot .291879$ & 1.489088 \\
\hline C & -3.329859 & -0.094744 & 2.744227 \\
\hline C & -3.547222 & -1.132098 & 3.644856 \\
\hline C & -3.197404 & -2.431111 & 3. 291631 \\
\hline C & -2.637744 & -2.670995 & 2.043610 \\
\hline C & -2.448892 & -1.606411 & 1.171924 \\
\hline $\mathrm{N}$ & -1.908194 & 2.960585 & -0.997211 \\
\hline C & -2.490193 & 3.400866 & -2.104384 \\
\hline $\mathrm{H}$ & -3.378612 & 2.861121 & -2.428951 \\
\hline C & -1.998619 & 4.496202 & -2.826801 \\
\hline $\mathrm{H}$ & -2.518474 & 4.824837 & -3.722716 \\
\hline C & -0.860721 & 5.136655 & -2.381529 \\
\hline $\mathrm{H}$ & -0.451106 & 5.988214 & -2.924217 \\
\hline C & -0.222694 & 4.690975 & -1.209181 \\
\hline C & 0.962523 & 5.280131 & -0.664137 \\
\hline $\mathrm{H}$ & 1.418443 & 6.117591 & -1.190470 \\
\hline C & 1.502501 & 4.812361 & ๑.494945 \\
\hline $\mathrm{H}$ & 2.400974 & 5.271896 & 0.907085 \\
\hline C & 0.910383 & 3.720945 & 1.211221 \\
\hline C & 1.428993 & 3.235425 & 2.432064 \\
\hline $\mathrm{H}$ & 2.318823 & 3. 699812 & 2.857769 \\
\hline C & 0.817724 & 2.180104 & 3.070085 \\
\hline $\mathrm{H}$ & 1.218642 & 1.811958 & 4.012527 \\
\hline C & -0.312987 & 1.539341 & 2.510468 \\
\hline $\mathrm{H}$ & -0.768813 & $\odot .714104$ & 3.056629 \\
\hline C & -0.870738 & 1.976922 & 1.302964 \\
\hline C & -0.235298 & 3. 096511 & 0.676816 \\
\hline C & $-\odot .795536$ & 3.594304 & -0.534619 \\
\hline C & 3.287230 & -0.236777 & ๑. 085232 \\
\hline C & 3.247848 & ๑. 095813 & 1.435497 \\
\hline C & 3.981149 & 1.139914 & 1.985182 \\
\hline C & 4.796936 & 1.901470 & 1.159685 \\
\hline C & 4.894827 & 1.582741 & -0.190219 \\
\hline C & 4.159553 & $\odot .515656$ & -0.696123 \\
\hline $\mathrm{N}$ & ๑.679891 & -3.113040 & -1.460822 \\
\hline C & 0.525024 & -4.394457 & -1.153474 \\
\hline $\mathrm{H}$ & 1.237595 & -4.811802 & -0.444678 \\
\hline
\end{tabular}




$\begin{array}{lrrr}\mathrm{C} & -0.493947 & -5.178947 & -1.705724 \\ \mathrm{H} & -0.578716 & -6.224009 & -1.421584 \\ \mathrm{C} & -1.369723 & -4.604785 & -2.602777 \\ \mathrm{H} & -2.168982 & -5.192251 & -3.053758 \\ \mathrm{C} & -1.234320 & -3.246002 & -2.936892 \\ \mathrm{C} & -2.095887 & -2.551505 & -3.844928 \\ \mathrm{H} & -2.892490 & -3.110821 & -4.335272 \\ \mathrm{C} & -1.907401 & -1.229399 & -4.108279 \\ \mathrm{H} & -2.551344 & -0.713734 & -4.821936 \\ \mathrm{C} & -0.856350 & -0.480935 & -3.483384 \\ \mathrm{C} & -0.629820 & 0.885236 & -3.746193 \\ \mathrm{H} & -1.264857 & 1.405068 & -4.464355 \\ \mathrm{C} & 0.396635 & 1.547843 & -3.109262 \\ \mathrm{H} & 0.576488 & 2.601445 & -3.321844 \\ \mathrm{C} & 1.220024 & 0.892900 & -2.170751 \\ \mathrm{H} & 1.999841 & 1.470883 & -1.674253 \\ \mathrm{C} & 1.049220 & -0.461946 & -1.881011 \\ \mathrm{C} & 0.001680 & -1.136559 & -2.575840 \\ \mathrm{C} & -0.188430 & -2.527147 & -2.328459 \\ \mathrm{~N} & -3.968221 & 0.535868 & -1.024089 \\ \mathrm{C} & -4.793246 & 0.031281 & -1.657208 \\ \mathrm{C} & -5.823240 & -0.608223 & -2.447680 \\ \mathrm{H} & -6.444617 & 0.143187 & -2.946710 \\ \mathrm{H} & -6.463265 & -1.220742 & -1.803168 \\ \mathrm{H} & -5.364171 & -1.252923 & -3.205597 \\ \mathrm{~N} & 3.176856 & -3.119098 & 0.494141 \\ \mathrm{C} & 3.827320 & -3.808852 & 1.155058 \\ \mathrm{C} & 4.644172 & -4.668420 & 1.984948 \\ \mathrm{H} & 4.087436 & -4.968571 & 2.879374 \\ \mathrm{H} & 5.549150 & -4.134698 & 2.295102 \\ \mathrm{H} & 4.937024 & -5.565695 & 1.429036\end{array}$


Table S7. DFT-Optimized coordinates of $\left[\left(\mathrm{C}_{6} \mathrm{~F}_{5}\right)(\mathrm{bzq})\left(\mathrm{PPh}_{3}\right) \operatorname{PtAg}\left(\mathrm{pyMe}_{2}\right)\right]^{+}(\mathbf{1 1 M e})$

\begin{tabular}{|c|c|c|c|}
\hline Center & $\mathrm{Co}$ & linates (An & troms) \\
\hline & $X$ & $\mathrm{Y}$ & Z \\
\hline$\overline{\mathrm{Pt}}$ & -0.204245 & -0.537548 & -0.655999 \\
\hline $\mathrm{Ag}$ & 2.291457 & $\odot .729911$ & -0.144665 \\
\hline $\mathrm{P}$ & -2.070671 & -0.771623 & $\odot .796370$ \\
\hline $\mathrm{F}$ & $-\odot .023262$ & 2.273495 & $\odot .908505$ \\
\hline $\mathrm{F}$ & $-\odot .719967$ & 4.738299 & 0.171230 \\
\hline $\mathrm{F}$ & -1.979432 & 5.167007 & -2.211132 \\
\hline $\mathrm{F}$ & -2.494770 & 3.070154 & -3.854342 \\
\hline $\mathrm{F}$ & -1.754836 & 0.581386 & -3.155833 \\
\hline $\mathrm{N}$ & $\odot .728607$ & -2.483100 & -0.335683 \\
\hline $\mathrm{N}$ & 3.252873 & 1.571889 & 1.626404 \\
\hline C & -0.829858 & 1.330587 & -1.118261 \\
\hline C & -0.615560 & 2.428930 & -0.299210 \\
\hline C & $-\odot .981868$ & 3.722738 & -0.644730 \\
\hline C & -1.619846 & 3.943750 & -1.858657 \\
\hline C & -1.877443 & 2.866546 & -2.700603 \\
\hline C & -1.479507 & 1.590240 & -2.318745 \\
\hline C & $\odot .374676$ & -3.450469 & $\odot .504592$ \\
\hline C & 1.043705 & -4.678313 & $\odot .573589$ \\
\hline C & 2.106696 & -4.909904 & $-\odot .270897$ \\
\hline C & 2.510740 & -3.906738 & -1.169863 \\
\hline C & 3.590721 & -4.064283 & -2.095523 \\
\hline C & 3.927636 & -3.062337 & -2.950680 \\
\hline C & 3. 232619 & -1.809663 & -2.939678 \\
\hline C & 3.567369 & -0.748234 & -3.809158 \\
\hline C & 2.878340 & 0.442477 & -3.754449 \\
\hline C & 1.827766 & ๑. 628251 & -2.828375 \\
\hline C & 1.445876 & $-\odot .388602$ & -1.944692 \\
\hline C & 2.174479 & -1.616008 & -2.025335 \\
\hline C & 1.799105 & -2.688731 & -1.158410 \\
\hline C & -3.278552 & -2.021034 & 0.254731 \\
\hline C & -2.990447 & -2.819820 & -0.855544 \\
\hline C & -3.912576 & -3.766153 & -1.294610 \\
\hline C & -5.125671 & -3.912954 & -0.631259 \\
\hline C & -5.426942 & -3.108094 & 0.466284 \\
\hline C & -4.511520 & -2.160606 & 0.905353 \\
\hline C & -1.483498 & -1.263711 & 2.457202 \\
\hline C & -0.377278 & $-\odot .574443$ & 2.975444 \\
\hline C & 0.148225 & $-\odot .923641$ & 4.213815 \\
\hline C & $-\odot .409912$ & -1.976160 & 4.936992 \\
\hline C & -1.500695 & -2.669612 & 4.424106 \\
\hline C & -2.041123 & -2.313669 & 3.190407 \\
\hline C & -3.082237 & 0.723760 & 1.052016 \\
\hline C & -3.017271 & 1.488048 & 2.217150 \\
\hline C & -3.752391 & 2.667070 & 2.317848 \\
\hline C & -4.554359 & 3.083137 & 1.261360 \\
\hline C & -4.628936 & 2.317395 & ๑. 098652 \\
\hline C & -3.893531 & 1.145070 & $-\odot .0 \odot 9 \odot \odot 7$ \\
\hline C & 3.619527 & $\odot .728626$ & 2.614318 \\
\hline C & 4.114077 & 1.214409 & 3.818765 \\
\hline C & 4.234525 & 2.587443 & 3.996864 \\
\hline
\end{tabular}




$\begin{array}{rrrr}\mathrm{C} & 3.860538 & 3.441006 & 2.970248 \\ \mathrm{C} & 3.363874 & 2.905870 & 1.784266 \\ \mathrm{C} & 3.470835 & -0.736977 & 2.356443 \\ \mathrm{C} & 2.917621 & 3.779151 & 0.658001 \\ \mathrm{H} & -0.474182 & -3.246465 & 1.155108 \\ \mathrm{H} & 0.705669 & -5.429189 & 1.282316 \\ \mathrm{H} & 2.639379 & -5.860309 & -0.253629 \\ \mathrm{H} & 4.129451 & -5.010793 & -2.107145 \\ \mathrm{H} & 4.740189 & -3.197452 & -3.663808 \\ \mathrm{H} & 4.378101 & -0.884994 & -4.524057 \\ \mathrm{H} & 3.140642 & 1.253060 & -4.431915 \\ \mathrm{H} & 1.284165 & 1.574976 & -2.831471 \\ \mathrm{H} & -2.048197 & -2.681569 & -1.389562 \\ \mathrm{H} & -3.686022 & -4.378767 & -2.164956 \\ \mathrm{H} & -5.848675 & -4.648513 & -0.978653 \\ \mathrm{H} & -6.383940 & -3.213613 & 0.973518 \\ \mathrm{H} & -4.759140 & -1.514843 & 1.749125 \\ \mathrm{H} & 0.060854 & 0.246835 & 2.402830 \\ \mathrm{H} & 0.997771 & -0.372467 & 4.616693 \\ \mathrm{H} & 0.006349 & -2.254809 & 5.903177 \\ \mathrm{H} & -1.939641 & -3.490963 & 4.987288 \\ \mathrm{H} & -2.893377 & -2.864728 & 2.793350 \\ \mathrm{H} & -2.396597 & 1.167239 & 3.053191 \\ \mathrm{H} & -3.700777 & 3.257877 & 3.230295 \\ \mathrm{H} & -5.127916 & 4.004359 & 1.342526 \\ \mathrm{H} & -5.260099 & 2.637139 & -0.728590 \\ \mathrm{H} & -3.949464 & 0.550032 & -0.922908 \\ \mathrm{H} & 4.410499 & 0.517094 & 4.599161 \\ \mathrm{H} & 4.624236 & 2.988245 & 4.930504 \\ \mathrm{H} & 3.947271 & 4.519951 & 3.074755 \\ \mathrm{H} & 2.411784 & -1.008095 & 2.221700 \\ \mathrm{H} & 3.863484 & -1.331726 & 3.188634 \\ \mathrm{H} & 4.008908 & -1.031850 & 1.443432 \\ \mathrm{H} & 3.310234 & 4.796445 & 0.760274 \\ \mathrm{H} & 1.821041 & 3.846104 & 0.634311 \\ \mathrm{H} & 3.253194 & 3.378386 & -0.309328 \\ & & & \end{array}$


Table S8. Emission data for compounds 1-5 in solution $\left(10^{-3} \mathrm{M}\right)$ at $77 \mathrm{~K}$

\begin{tabular}{|c|c|c|c|c|}
\hline Compound & & $\lambda_{\text {exc }} / \mathrm{nm}$ & $\lambda_{\text {em }} / \mathrm{nm}$ & $\tau / \mu \mathrm{s}$ \\
\hline 1 & $\mathrm{CH}_{2} \mathrm{Cl}_{2}$ & 385 & $\begin{array}{c}474,507,548_{\mathrm{sh}} \\
579_{\max }, 610,667_{\mathrm{sh}}\end{array}$ & $\begin{array}{l}\text { 202.6(58.7\%), 51.5(41.3\%) }(474 \mathrm{~nm}) \\
95.8(69.2 \%), 64.0(30.8 \%)(579 \mathrm{~nm}) \\
323.9(44.0 \%), 39.6(60.0 \%)(610 \mathrm{~nm})\end{array}$ \\
\hline \multirow[t]{2}{*}{2} & $\mathrm{CH}_{2} \mathrm{Cl}_{2}$ & 370 & $\begin{array}{l}\text { 472, 504, 545 } 5_{\mathrm{sh}} \\
\text { 578 } \\
\text { máx }, 607,665_{\mathrm{sh}}\end{array}$ & $\begin{array}{l}\text { 358.4(70.0\%), 1091.1 (30.0\%) }(472 \mathrm{~nm}) \\
725.7(77.0 \%), 116.0(33.0 \%)(504 \mathrm{~nm}) \\
581.3(33.0 \%), 922.7(67.0 \%)(578 \mathrm{~nm}) \\
387.4(24.0 \%), 869.6(76 \%)(607 \mathrm{~nm})\end{array}$ \\
\hline & $\begin{array}{l}\text { 2-Me- } \\
\text { THF }\end{array}$ & 370 & $\begin{array}{l}\text { 466, 476, 498, 510, } \\
\text { 539, 578 } 608_{\text {sh }}, 6 \text { áx } \\
\quad 640_{\text {sh }}\end{array}$ & \\
\hline 3 & $\mathrm{CH}_{2} \mathrm{Cl}_{2}$ & 370 & $\begin{array}{l}\text { 481, } 516,548_{\mathrm{sh}} \\
582_{\text {máx }}, 620,664_{\mathrm{sh}}\end{array}$ & $\begin{array}{l}\text { 58.6(68.4\%), 268.3(31.6\%) }(481 \mathrm{~nm}) \\
\text { 73.4(59.1\%), 212.0(48.9\%) }(516 \mathrm{~nm}) \\
178.8(81.6 \%), 31.9(18.4)(582 \mathrm{~nm}) \\
21.1(47.6 \%), 173.0(52.4)(620 \mathrm{~nm}) \\
\end{array}$ \\
\hline \multirow[t]{2}{*}{4} & $\mathrm{CH}_{2} \mathrm{Cl}_{2}$ & 400 & $\begin{array}{c}\text { 468,478, 501, } \\
544_{\text {sh, }} 588_{\text {sh, }} 606_{\text {máx }}\end{array}$ & $\begin{array}{l}\text { 426.9(41.3\%), 86.1(58.7\%) }(468 \mathrm{~nm}) \\
293.4(57.8 \%), 560.9(42.2 \%)(478 \mathrm{~nm}) \\
559.0(55.4 \%), 245.7(44.6 \%)(588 \mathrm{~nm}) \\
95.2(33.4 \%), 458.0(66.6 \%)(606 \mathrm{~nm})\end{array}$ \\
\hline & $\begin{array}{l}\text { 2-Me- } \\
\text { THF }\end{array}$ & 370 & $\begin{array}{l}\text { 464, 475, 496, 510, } \\
537,573_{\mathrm{sh}}, 600_{\max } \\
\quad 644\end{array}$ & \\
\hline \multirow[t]{2}{*}{5} & $\mathrm{CH}_{2} \mathrm{Cl}_{2}$ & 400 & $\begin{array}{l}471,503,540_{\mathrm{sh}} \\
568_{\max }, 601_{\mathrm{sh}}\end{array}$ & $\begin{array}{l}\text { 559.6(65.5\%), 97.0(34.5\%) }(471 \mathrm{~nm}) \\
\text { 280.6(65.5\%), 785.3(11.7\%) }(503 \mathrm{~nm}) \\
\text { 473.1(64.2\%), } 122.1(35.8 \%)(540 \mathrm{~nm}) \\
\text { 198.2(53.8), 552.4(46.2\%) }(568 \mathrm{~nm})\end{array}$ \\
\hline & $\begin{array}{l}\text { 2-Me- } \\
\text { THF }\end{array}$ & 380 & $\begin{array}{l}463,478,514,541 \\
579_{\text {sh }}, 608_{\max }, 648_{\text {sh }}\end{array}$ & \\
\hline 7 & $\mathrm{CH}_{2} \mathrm{Cl}_{2}$ & 370 & $\begin{array}{l}479,500,580 \\
\quad 617_{\max }\end{array}$ & $\begin{array}{l}\text { 23.3(88.6\%), 221.3(11.4\%) }(479 \mathrm{~nm}) \\
24.0(98.9 \%), 148.4(1.1 \%)(580 \mathrm{~nm}) \\
23.9(97.5 \%), 20.7(2.5 \%)(617 \mathrm{~nm})\end{array}$ \\
\hline 8 & $\mathrm{CH}_{2} \mathrm{Cl}_{2}$ & 390 & 489, 526, 592 máx & \\
\hline 9 & $\mathrm{CH}_{2} \mathrm{Cl}_{2}$ & 390 & 484, 520sh, 595 $\max$ & \\
\hline 11 & $\mathrm{CH}_{2} \mathrm{Cl}_{2}$ & 386 & $476,610_{\max }$ & $\begin{array}{l}\text { 33.3(87.3\%), 554.5(12.7\%) (476 nm) } \\
\text { 25.3(98.8\%), } 298.1(1.2 \%)(610 \mathrm{~nm})\end{array}$ \\
\hline
\end{tabular}




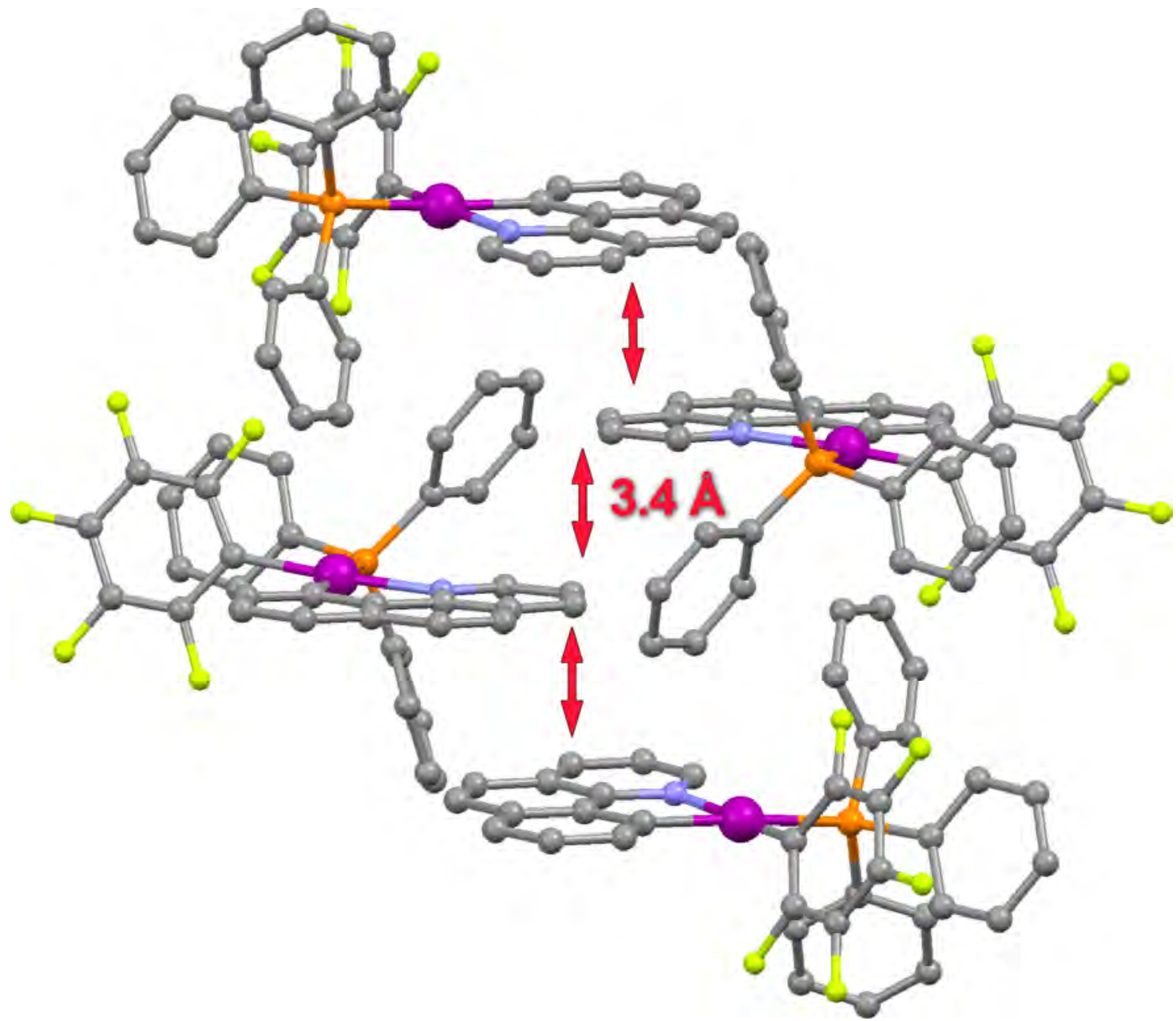

Figure S1. View of the supramolecular arrangement of the four units of the complex $\left[\mathrm{Pt}\left(\mathrm{C}_{6} \mathrm{~F}_{5}\right)(\mathrm{bzq})\left(\mathrm{PPh}_{3}\right)\right](2)$ showing the $\pi \cdots \pi$ stacking. 


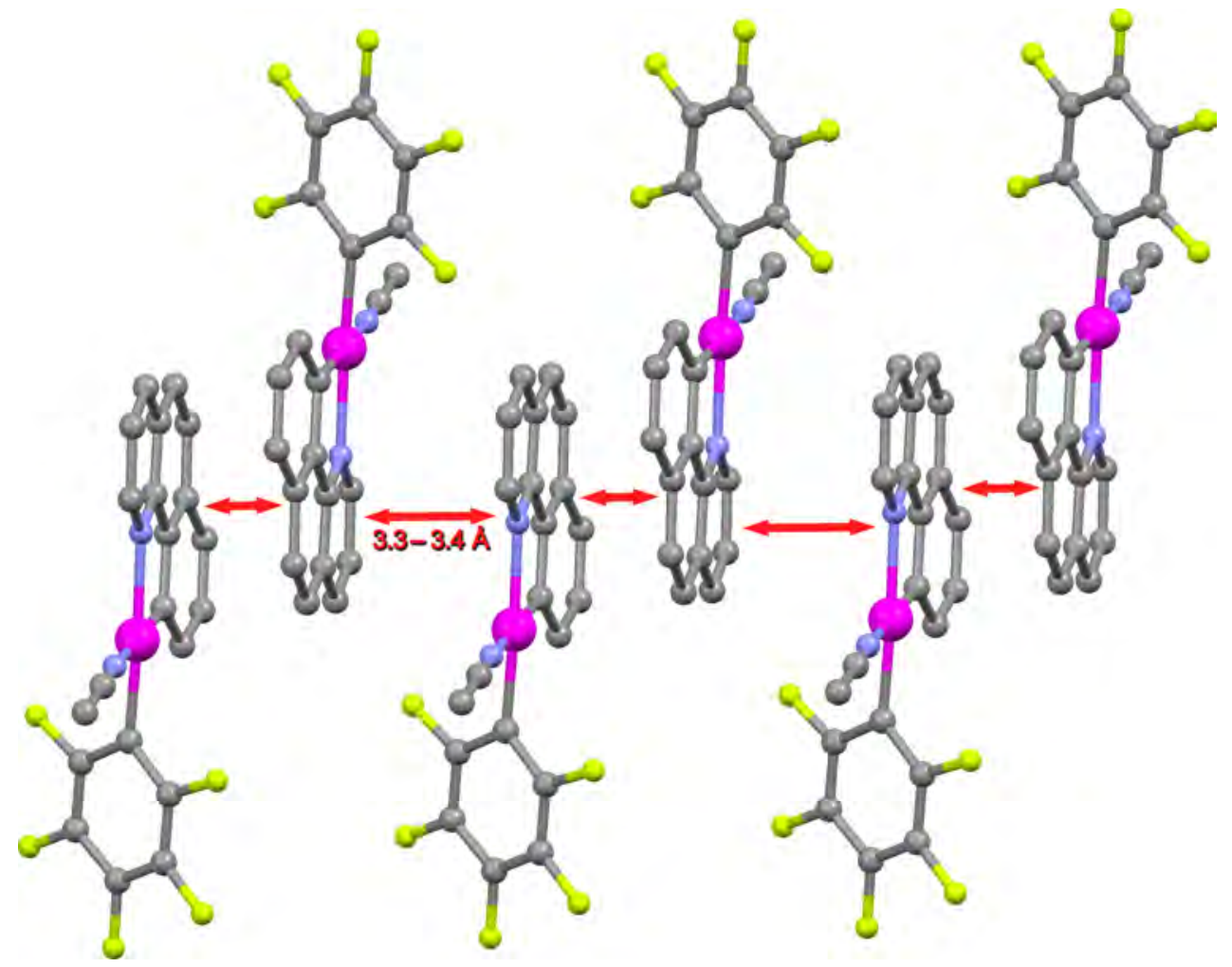

Figure S2. View of the supramolecular arrangement of the infinite array for the complex $\left[\mathrm{Pt}\left(\mathrm{C}_{6} \mathrm{~F}_{5}\right)(\mathrm{bzq})(\mathrm{MeCN})\right](5)$ showing the $\pi \cdots \pi$ stacking. 


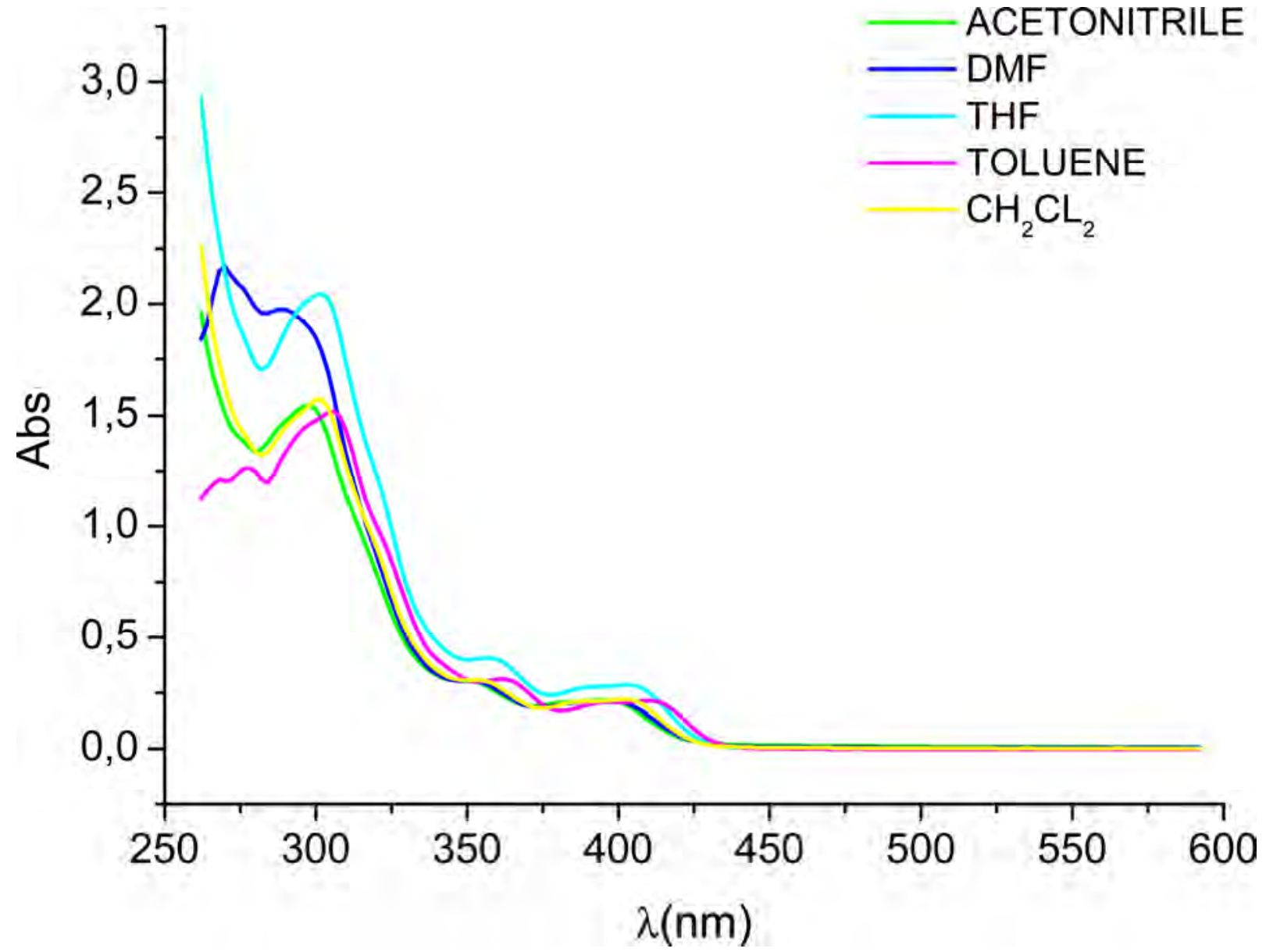

Figure S3. Absorption spectra of 2 in solution of different solvents $\left(10^{-4} \mathrm{M}\right)$ at room temperature. 

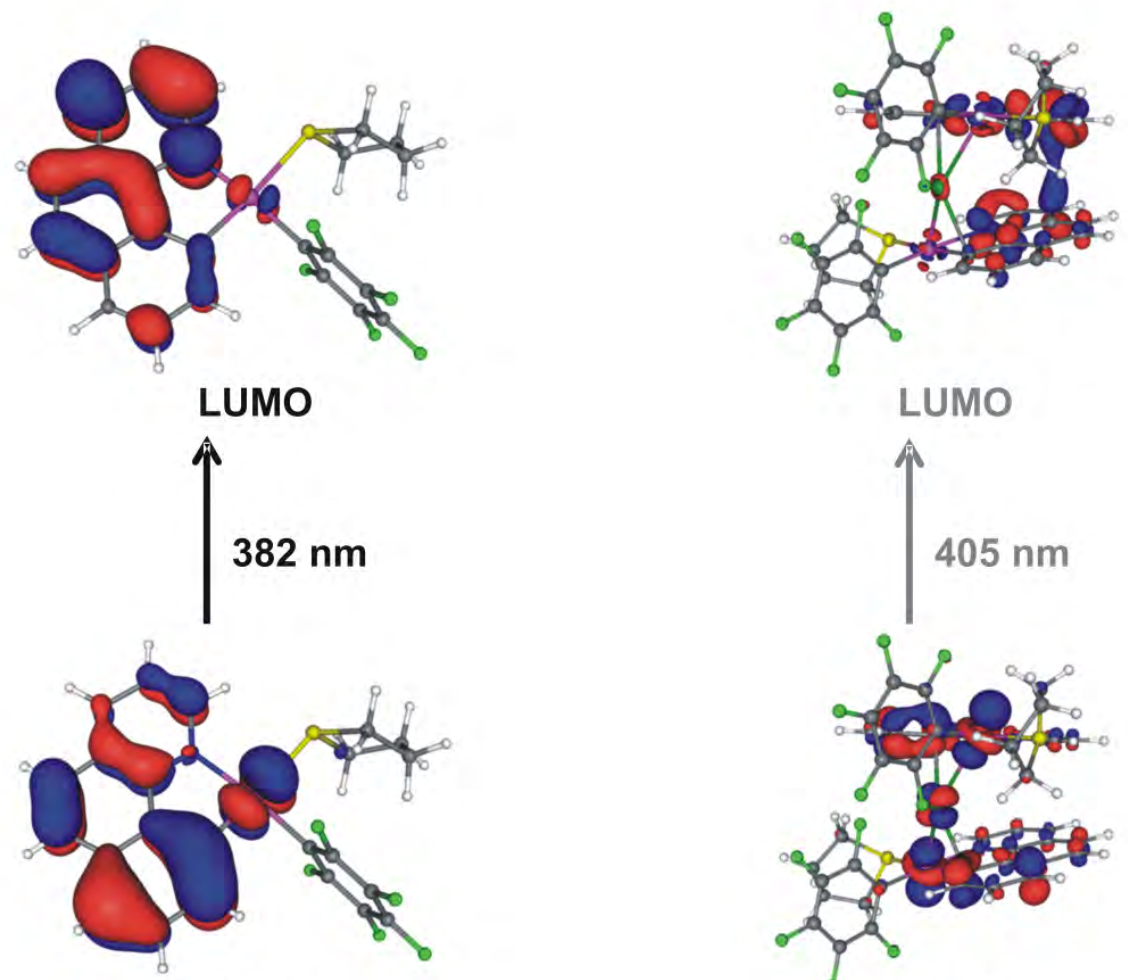

LUMO

HOMO

HOMO

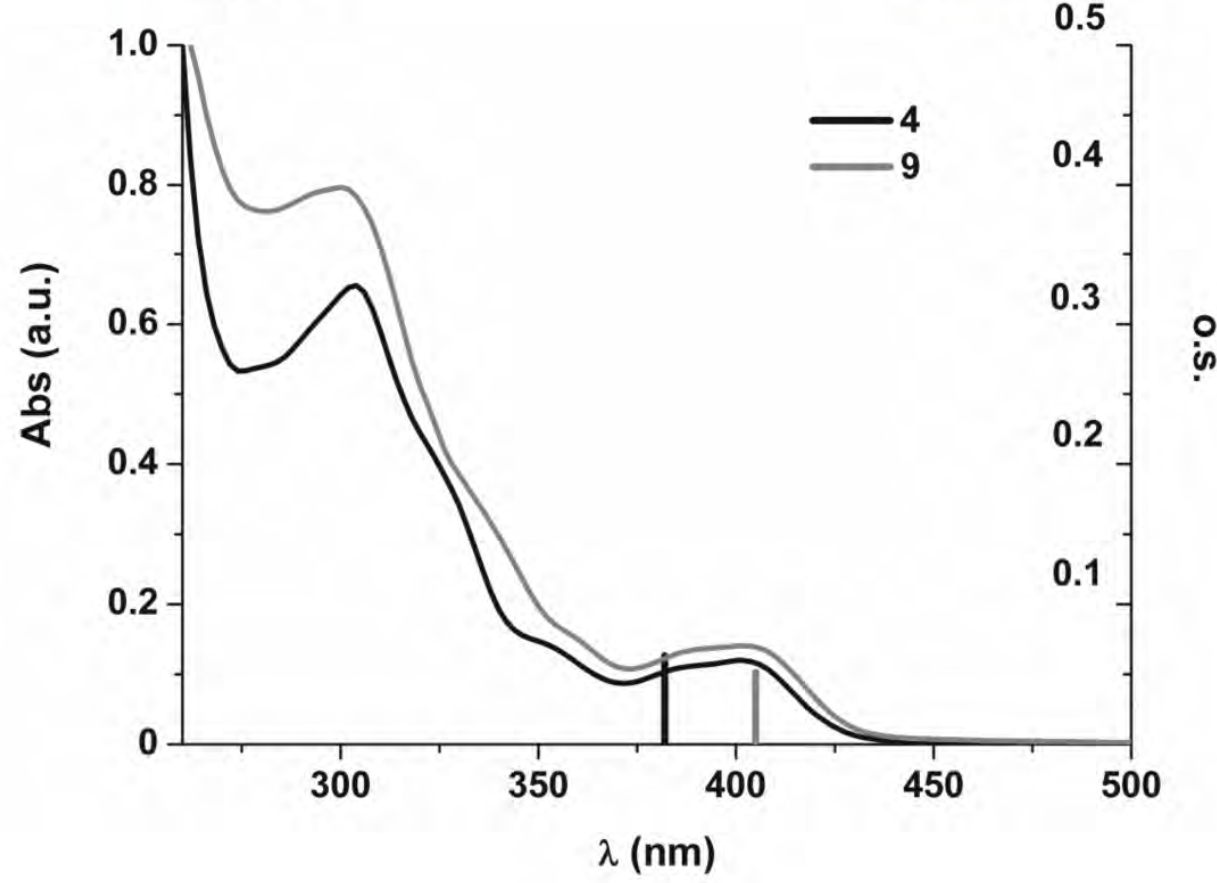

Figure S4: Frontier orbitals plots for complexes $\mathbf{4}$ and $\mathbf{9}$ in $\mathrm{CH}_{2} \mathrm{Cl}_{2}$ obtained by DFT; calculated electronic transitions (bars) and experimental UV-vis spectrum of 4 and 9 in $\mathrm{CH}_{2} \mathrm{Cl}_{2}\left(10^{-4} \mathrm{M}\right)$. 


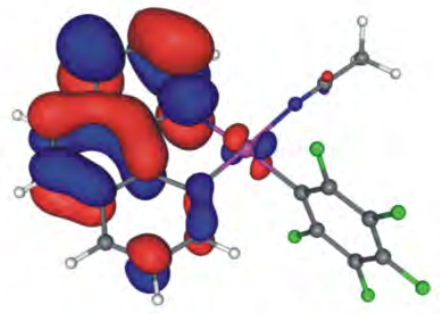

LUMO

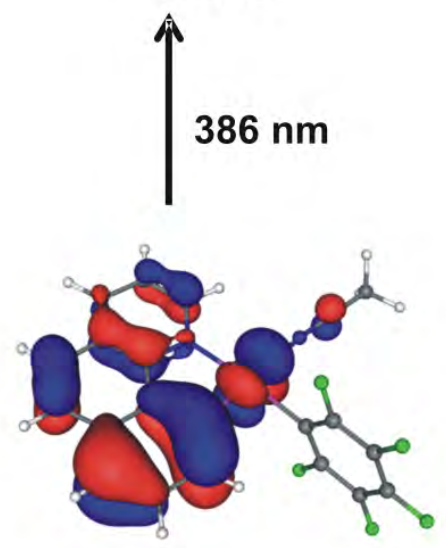

HOMO

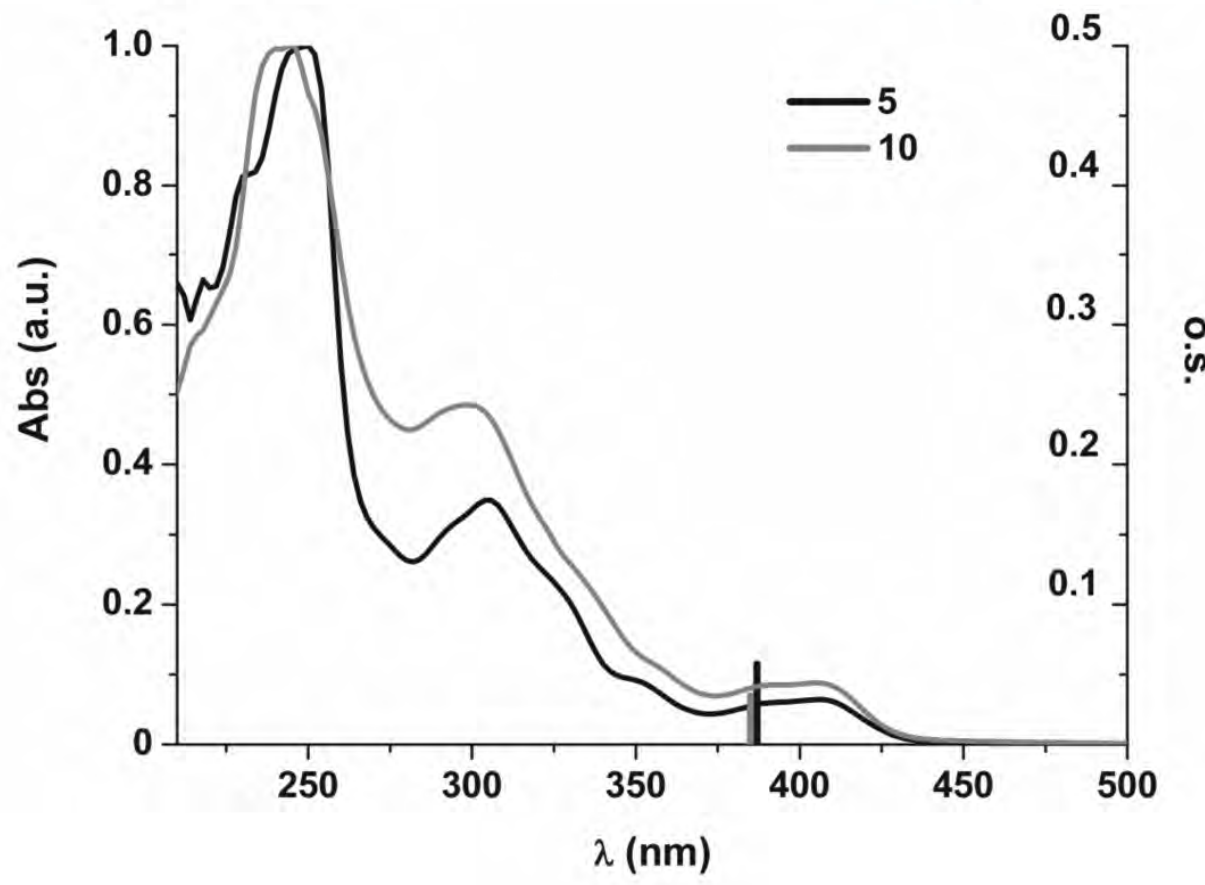

Figure S5: Frontier orbitals plots for complexes $\mathbf{5}$ and $\mathbf{1 0}$ in $\mathrm{CH}_{2} \mathrm{Cl}_{2}$ obtained by DFT; calculated electronic transitions (bars) and experimental UV-vis spectrum of $\mathbf{5}$ and $\mathbf{1 0}$ in $\mathrm{CH}_{2} \mathrm{Cl}_{2}\left(10^{-4} \mathrm{M}\right)$. 


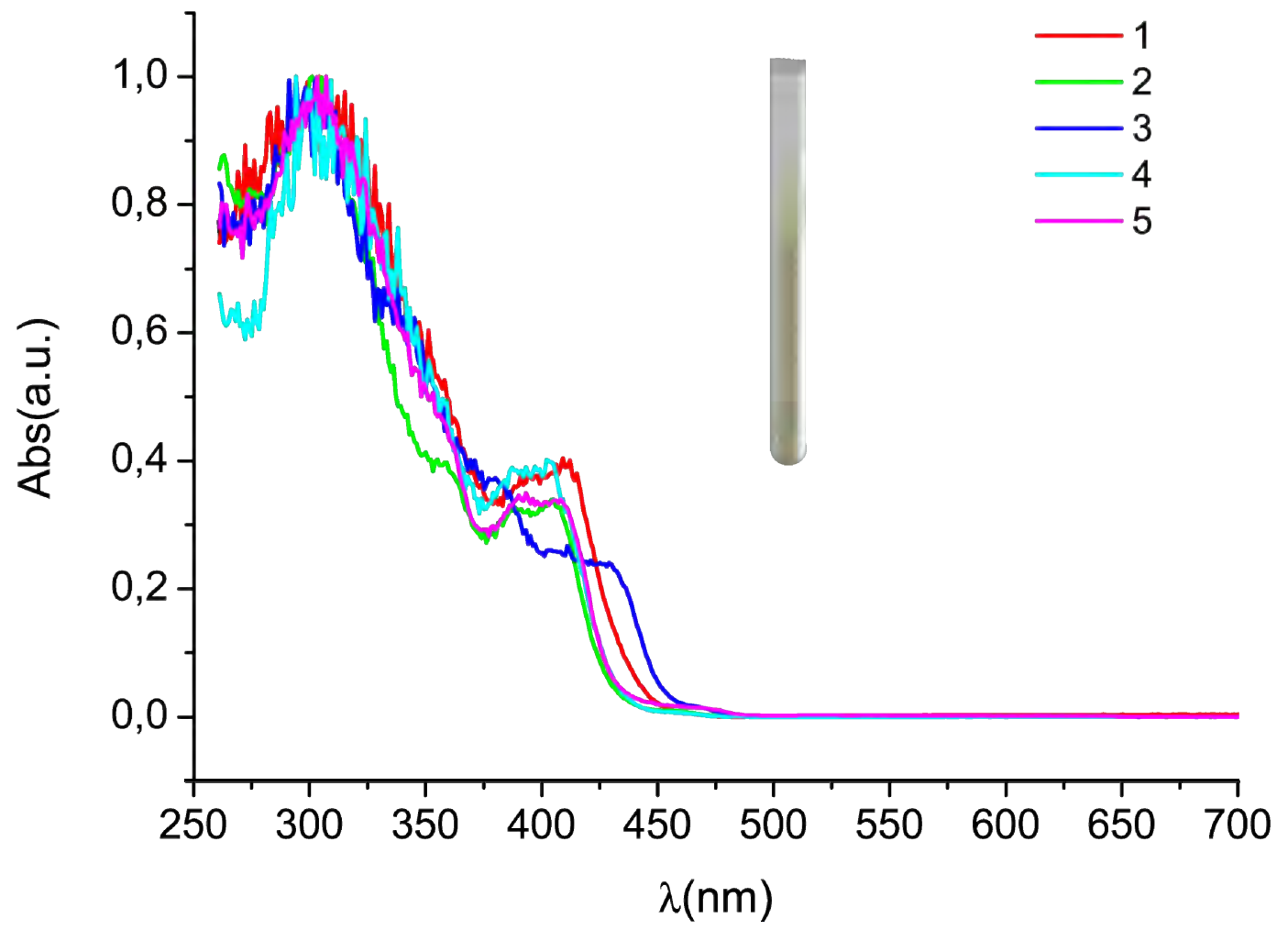

Figure S6. Normalized DRUV spectra of complexes 1-5 in the solid state. Inset image: compound 2 at 298K. 


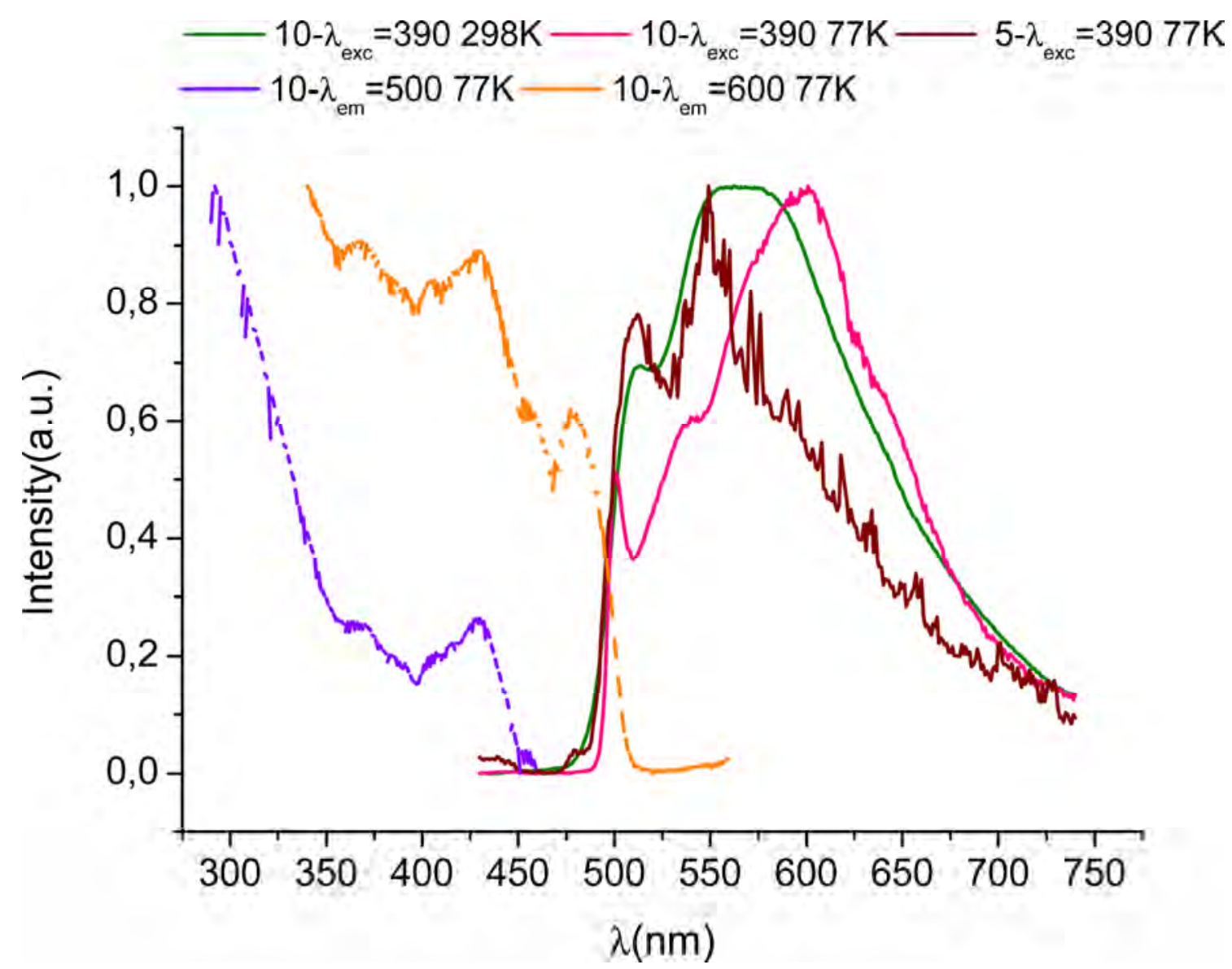

Figure S7. Normalized emission and excitation spectra of $\mathbf{5}$ and $\mathbf{1 0}$ in the solid state. 